\title{
Teaching Gifted and Talented Children in A New Educational Era
}

Edited by

Mojca Kukanja Gabrijelčič Maruška Seničar Željeznov 

Teaching Gifted and Talented Children 
Knjižnica Ludus · 14 · ISSN 2536-1937

Series Editor · Silva Bratož

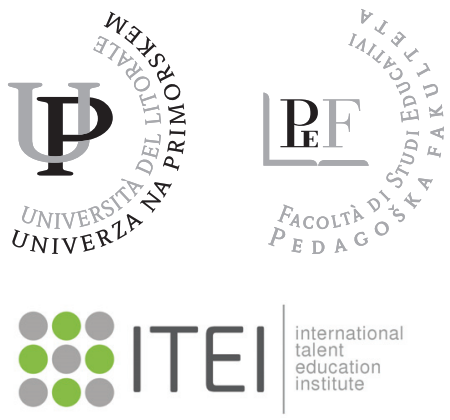

Izdajo monografije je omogočil International Talent Education Institute, ki deluje v okviru MIB d.o.o. 


\section{Teaching Gifted}

and Talented Children

in A New Educational Era

Edited by

Mojca Kukanja Gabrijelčič

Maruška Seničar Željeznov

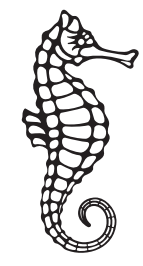




\section{Teaching Gifted and Talented Children in A New Educational Era}

Edited by · Mojca Kukanja Gabrijelčič

Maruška Seničar Željeznov

Reviewers · Ivan Ferbežer

Drawings and Layout · Alen Ježovnik

Knjižnica Ludus · 14 · ISSN 2536-1937

Series Editor · Silva Bratož

Published by · University of Primorska Press

Titov trg 4, 600o Koper

www.hippocampus.si

Editor in Chief · Jonatan Vinkler

Managing Editor · Alen Ježovnik

Koper $\cdot 2018$

http://www.hippocampus.si//SBN/978-961-7055-22-1.pdf

http://www.hippocampus.si/ISBN/978-961-7055-23-8/index.html

https://doi.org/10.26493/978-961-7055-22-1

(c) 2018 University of Primorska Press

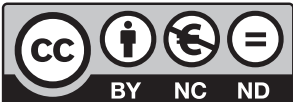

Kataložni zapis o publikaciji (CIP) pripravili v Narodni in univerzitetni knjižnici v Ljubljani

COBISS.SI-ID $=296558592$

ISBN 978-961-7055-22-1 (pdf)

ISBN 978-961-7055-23-8 (html) 


\section{Table of Contents}

Promoting Giftedness through 'English as a Lingua Franca' Informed Language

Teaching

Eva Knechtelsdorfer $\cdot 7$

Contributors of High Achieving Students' Linguistic Competence

Theodoros P. Kokkinos, Aikaterini D. Gari, and Lavrentios G. Dellassoudas · 17

Exploring Dutch Students' Implicit Theories of an Intelligent Person

Trudie G. C. Malotaux-Christophersen, Sven A. C. Mathijssen, and Lianne Hoogeveen · 33

Gifted Children's Drawings and Significant Others' Needs

Aikaterini D. Gari, Athina Papakonstantinou, loanna Mandaliou, Vassiliki Nikolopoulou, and Theodoros Kokkinos 53

Teacher Strategies to Motivate Gifted Students: A Multiple Case Study on Teacher Behavior

Greet C. De Boer, Marie-Christine J. L. Opdenakker, and Alexander E. M. G. Minnaert · 75

Relationship between Encouraging Excellence in Pupils and Teachers' Attitudes towards Science: An Example from Croatia

Petra Pejić Papak, Jasna Arrigoni, and Željka Ivković · 99

Didactic Strategies in the Function of Developing Intellectual Talents of Gifted Students Aleksandar Stojanović • 119

How Kindergarten Teachers Perceive Giftedness and What They Require for Their Work with Gifted Preschool Children

Maruška Željeznov Seničar and Borut Seničar $\cdot 133$

Fostering Mathematically Gifted Students with Complex Fields of Problems

Marianne Nolte $\cdot 147$ 



\title{
Promoting Giftedness through 'English as a Lingua Franca' Informed Language Teaching
}

\author{
Eva Knechtelsdorfer \\ University College of Teacher Education Vienna/Krems, Austria \\ eva.knechtelsdorfer@kphvie.ac.at
}

\begin{abstract}
Promotion of giftedness is the development of an individual's potential taking into account their environment and personal character traits. However, while extracurricular enrichment activities, pull-out courses and other didactic interventions focus on the individual's potential, personalization in regular classrooms is still an area in need of improvement in school systems worldwide. The aim of this research paper is to examine possible didactic adaptions in the English foreign language classroom in Austria. The concept of English as a Lingua Franca, in other words the international use of English in different linguacultural settings, sets the basis for English classes that focus on students' linguistic capabilities and further developing these. As nowadays students are likely going to engage more in conversations with non-native speakers, it is necessary to teach strategies to cope better with ELF situations influenced by diverse lingua-cultural backgrounds of the interlocutors. By analysing the learners' linguistic and cultural background as well as the purpose for which they study the language, it is possible to meet the challenges of classrooms diverse in cultures and potential. The main goal of English language teaching should, therefore, not be the illusive native-speaker-like knowledge of English but the development of students' own language capabilities. This means that students should be capable of using English as a resource with all its conformist and non-conformist realizations depending on their personal potential and the lingua-cultural settings they communicate in. This way students' individual potentials are the focal point of language instruction and their development can be promoted accordingly.
\end{abstract}

Keywords: potential development, English language teaching, English as a lingua franca

\section{Introduction}

In times of globalization, English is the international medium of communication in the public, political and economic domain and, when we think of the Erasmus generation, even in the private domain. International conferences are held in English, world trade relies to a certain extent on the use of English of all trade partners and institutions such as the United Nations and 
the European Union partly communicate in English. Increasingly more people worldwide study, work and live abroad thus creating international relationships and communicating in English. It is, therefore, crucial to acknowledge the special role English as a foreign language plays and to take certain phenomena of this international use of English into consideration when teaching English. Thus far traditional English language teaching in Austria, and presumably in other countries as well, focuses on the standard variety of English using the Common European Framework of References (CEFR) as the basis for curricula and testing. It is not only ignoring the special position of English globally but also does not account for the individual, multilingual and multicultural potential of language learners.

Research into English as a Lingua Franca, ELF, suggests that it is 'a means of intercultural communication not tied to particular countries and ethnicities, a linguistic resource that is not contained in, or constrained by, traditional (and notoriously tendentious) ideas of what constitutes "a language"' (Seidlhofer, 2011, p. 81). The aim of this paper is to examine the ways in which a focus on ELF in English language teaching can contribute to the promotion of giftedness. A revised definition of communicative competence provides the linguistic and didactic framework for ELF-informed language teaching. To illustrate possible areas of change in English language classrooms, examples of ELF-informed language teaching are provided.

\section{English as Lingua Franca}

English is, according to the Eurobarometer (Commission of the European Communities, 2012, p. 21), the most widely spoken foreign language in the European Union and, in addition, it is also the number one foreign language taught in schools. It is used internationally for different purposes by people with diverse L1. As a result of this changed role of English, English as a Lingua Franca (ELF) research started to create first interesting insights into this new phenomenon. The accepted definition of ELF defines it as 'any use of English among speakers of different first languages for whom English is the communicative medium of choice, and often the only option' (Seidlhofer, 2011, p. 7).

While critics claim ELF to be a wrong and degenerated variety of English, ELF research suggests the opposite to be true. Firstly, ELF is not a fixed variety and can, therefore, not be treated and analysed as one. It is rather a flexible use of English, created ad hoc, depending on the sociocultural setting, the interlocutors' L1 and the communicative goal of the conversation (Seidlhofer, 2011, p. 80). It is, thus, not a variety that is less valid or correct than the standard language but is a use of the potential of English with all its conformist 
and non-conformist options. In every communicative situation interlocutors choose from the virtual language and decide which rules of the standard language to adhere to and which to interpret creatively as to accommodate to the communicative goal as well as the interlocutors' needs.

At the moment, foreign language teaching focuses to a great extent on linguistic conventions of the native speaker, which are only sometimes complemented by audio and textual material from English used in countries such as India, so English varieties in former colonies. Kachru's (1992) World English model of three concentric circles illustrates different uses of English. The Inner Circle represents native speaker use of English in countries such as the USA and UK and is the smallest. Next is the Outer Circle which describes English as second language in countries like India and Nigeria. Around 150-300 million people use English in this context. The Expanding Circle shows the biggest number of speakers, 100-1.000 million, using English as a foreign language. Kachru's circle model distinguishes quite clearly between different uses of English and highlights the vast number of people who speak English as a foreign language.

Despite the fact, that there are more non-native speakers using English regularly than native speakers, insights of ELF research have had no influence on English language teaching and testing practices. Interestingly, native speakers show less flexibility in their language use, while ELF users make use of all their (multi)linguistic resources, not necessarily adhering to conventions of the standard language. In international communication this might even lead to an advantage for non-native speakers (Jenkins, Cogo, \& Dewey, 2011, p. 284; Seidlhofer, 2011, p. 80).

A driving force behind language teaching and assessment in the European Union is the Common European Framework of Reference (Council of Europe, 2001), which describes language competence measuring different levels of competence against the native speaker standard. The highest level, $\mathrm{C}_{2}$, is in this description the native-like use of the language and all other levels are measured in accordance with this 'authentic' use of the language. Research questions the existence of a native speaker and discussion on the ownership of English (e.g. Widdowson, 2003, pp. 35-45) have led to a revision of the wording of the CEFR. A new version (Council of Europe, 2016), only recently published for international evaluation, uses the term proficient speaker as the new goal to be reached by language learners. It remains unclear, however, to what extent this differs from the traditional native speaker norm.

And while critique on the concept ELF claims it promotes simplistic and wrong language teaching, Seidlhofer (2011, p. 198) proposes a new under- 
standing of what constitutes a language and what language teaching should focus on. Instead of teaching only a variety of English, students should learn to language (Jørgensen, 2008), so learn how to make use of the linguistic resources of the virtual language as well as their personal linguistic potential. Every language has conformist and non-conformist potential and it depends on the linguacultural situation and the communicative context which of these potentials are realized. This new way of understanding communication has its roots in Jørgensen's (2008) account on languaging.

\section{Communicative Capability and Potential Development}

Looking at English language teaching from an ELF perspective, it becomes obvious that traditional definitions of communicative competence, which are the basis for the CEFR, do not account for the international use of English. Neither do the competence models by Hymes (1972), Canale and Swain (1980) and Bachman and Palmer (1982) take into consideration the individual potential of a language learner. A focus on the development of communicative capability, so 'a knowledge of how meaning potential encoded in English can be realized as a communicative resource' (Widdowson, 2003, p. 177), shifts the objective of teaching from the subject English to the language learner.

Similarly to the basic model of the promotion of giftedness (Grabner, 2016), communicative capability starts with the potential of the individual, their (multi)linguistic identity, their communicative needs and their goals. While traditional definitions of communicative competence are subdivided into complex categories of what constitutes competence, Widdowson distils the essence of communicative capability, into one concise definition.

The preferred definition of giftedness in the pedagogic context says that one cannot measure potential (Weigand, 2016), just as one cannot measure communicative competence. This is why both fields suggest a focus on individual potential in order to achieve excellence and communicative success. It depends on factors of personality and the environment to develop potential. The dynamic understanding of potential (Roth, 1952), which is described in models of Renzulli (1986), Mönks (1992) and the Munich model (Heller, 2011), highlights the importance of potential development with a focus on personal and environmental factors. Hence, only when taking into consideration the individual, multilingual and multicultural potential of language learners as well as their personal communicative needs and goals can communicative capability and individual potential be developed. Potential of an individual as well as that of a language cannot be fully developed if not all factors, realized and not realized, conformist and non-conformist, are taken into con- 
Promotion of Giftedness

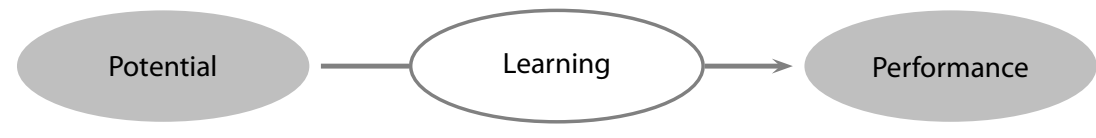

Communicative Capability

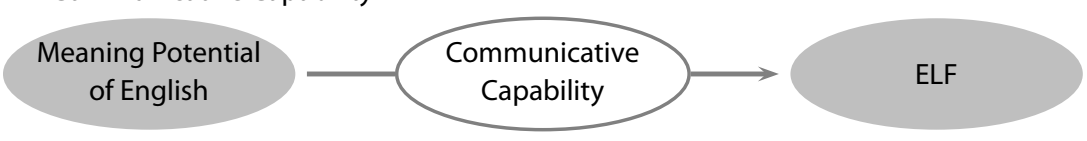

Figure 1 Promotion of Giftedness and Communicative Capability (adapted from Widdowson, 2003)

sideration. Communicative capability and ELF-influenced language teaching allow for a focus on individual potential in teaching and assessment as opposed to a focus on a lack of knowledge measured against an illusory native speaker standard.

Similar parallels between language and potential development models can also be drawn taking into consideration Gardner's (1991) thoughts on intelligence. In contrast to other researchers, Gardner was the first to define more than just cognitive intelligence. Similarly, in ELF contexts, the potential of the English language is not only described as the standard version but it takes into consideration also the unrealized, non-conformist potential of the language.

\section{Potential Development through ELF-Informed Language Teaching}

Two possible areas for the integration of ELF findings in English language teaching are pronunciation and communicative strategies. The Lingua Franca Core (Jenkins, 2000) suggests areas of pronunciation that are most crucial for mutual understanding in ELF situations. It is for example, in general, less important to perfectly pronounce a th while the differentiation between long and short vowels is crucial in ELF (e.g.: beach). Using a table, provided online (www.elfpron.wordpress.com), teachers could choose which pronunciation features to focus on depending on the linguistic potential of their students. Students with L1 Arabic or German would, according to the ELF grid, have to work on different areas of pronunciation (Table 1).

Besides a shifted focus in teaching pronunciation, it is crucial to make room for communicative strategies in English language classrooms (Kirkpatrick, 2007, p. 194). Communicative strategies are essential in communication, especially in ELF settings, as they are used to prevent communicative break- 
Table 1 Areas of Pronunciation in Arabic and German

\begin{tabular}{lll}
\hline Consonants & Arabic & German \\
\hline$/ \mathrm{p} /$ aspirated & - & - \\
$/ \mathrm{p} /$ & - & word initial \\
$/ \mathrm{b} /$ & in contrast to $/ \mathrm{p} /$ & \\
$/ \mathrm{t} /$ & & word initial \\
$/ \mathrm{k} /$ & in contrast to $/ \mathrm{g} /$ & word initial \\
\hline
\end{tabular}

down. Strategies used in ELF are for example descriptions, code-switching, foreignization, cooperation and reduction (Björkman, 2014).

As language teaching and testing focus on the correct use of native speaker Standard English, it is only logical that the intentional use of strategies such as code-switching and reduction are not validated or even penalized with bad grades. This can be seen in the assessment grid devised for the standardized Austrian oral Matura exam. Teachers assess a student's performance with band 0-10. Band 6-10 represent positive grades with various degrees, band 5 and below are negative performances. Test assessors need to grade the use of $L 1$, so code-switching, with band 2 or 3 , so negative. One factor in the descriptor of band 10, so the best band, is that the student does not describe or paraphrase. This demonstrates clearly that although research shows the importance of using communicative strategies for mutual intelligibility, language teaching and testing still discourages languages learners to use certain features of the virtual language.

Communicative strategies are, however, part of communication and the communicative capability of everybody, even in L1 encounters. It is common to paraphrase an utterance, if the interlocutor could not understand it, either acoustically or because of a gap in the shared knowledge of the interlocutors. This can happen in conversations between people of different generations, with different education or professions as well as differences in heritage culture and numerous other factors. And although new standardized tests are said to test language students actually use in situations they actually encounter as opposed to testing Shakespeare, they do lack a major aspect of authenticity. In the light of ELF it seems counterproductive to punish the use of strategies that are part of students' language capabilities and which they use strategically in order to communicate successfully. Although it is understandable that using communicative strategies might hint towards a lack in for example vocabulary knowledge, the strategic use of communicative strategies demonstrates flexibility and adaption, both of which are important in communication. 
A lack of awareness of the importance of communicative strategies is not only apparent in Austrian assessment documents but also in official EU publications such as Misused English Words and Expression in EU Publications (European Court of Auditors, 2016). This document claims to analyse and correct English words used in EU publications and documents, which are incorrect or not Standard English. It is stated that this is necessary because 'whereas EU staff should be able to understand "real" English, we cannot expect the general public to be au fait with the EU variety' (p. 4). An example of such wrong use of English words is 'actor' (p. 9). While in Standard English it can only stand for a person playing in a film or a play, the EU uses the meaning of the French and German word 'acteur/Akteur' namely people (and organizations) doing something. This clearly is an example of another communicative strategy used in international encounters by interlocutors with different $L 1$, namely foreignization. Interestingly the author states that native speakers are confused by the EU's use of the word and leaves out an analysis of non-native speakers. It can be assumed that due to the fact that this Romance word is used in more than just Romance languages, lots of EU citizens with different L1 will not struggle with the 'EU meaning,' as their shared knowledge of the virtual language is similar. Communicatively capable language learners and users can draw from experience in other languages and add new meaning to existing words. Foreignization can only work if the interlocutor is aware of the others' language capability and in how far this word is shared knowledge. They have to draw upon their linguistic and interpersonal potential in order to create new words. Effective use of foreignization can expand the meaning potential of the conformist meaning of an utterance. Foreignization, therefore, does not demonstrate incompetence but rather flexibility and the capability to make use of personal potential.

In conclusion it can be said that although the CEFR criticizes the use of these strategies, as they seem to show a lack of language knowledge, they are necessary in ELF communication. And quite on the contrary they show flexibility and monitoring control of personal (linguistic) potential.

\section{Conclusion}

The aim of this paper is to demonstrate how ELF-informed language teaching does not only promote a realistic goal for language learners but, more importantly, allows for a focus on their individual potential. ELF-informed language teaching focuses on language learner's communicative needs taking into consideration their multilingual and multicultural backgrounds and works towards reaching their personal communicative goals. 
Nowadays, it is no longer enough to teach towards the goal of native-like use of English but it is necessary to focus on the linguistic reality language learners are confronted with outside the classroom. This paper illustrates that despite the fact that English language teaching aims at preparing for conversations with native speakers, the significant amount of non-native speakers using English as their shared means of communication demands a shift in focus of English language classrooms. English as a Lingua Franca research shows that in ELF settings speakers need to use the meaning potential of English more flexible. And while teachers might focus on some aspects because they seem necessarily important for communication with native speakers, in ELF encounters other aspects are more important. This is why research such as the Lingua Franca Core suggest parts of pronunciation that are more important in ELF than in native speaker encounters (long and short vowels vs. th sound).

Besides pronunciation, this paper aims at highlighting the importance of communicative strategies. The intentional use of strategies to avoid communicative breakdown are, at the moment, penalized in language assessment. However, ELF research suggests that a flexible use of the virtual language and all of the meaning potential of English leads to mutual intelligibility, while adherence to conformist, native speaker usage does not necessarily in ELF settings.

ELF-informed language teaching, thus, starts from the individual's linguistic capability, their experience from $\mathrm{L} 1$ and other languages they might know. Every language learner can draw from experience in least one other language they speak, as English in this context is an additional language they learn. In their $L_{1}(\mathrm{Lx})$ they can recognize regularities and they are capable of applying rules of a language. They understand that grammar is the framework of a language and they understand pragmatic differences. In their L1 they are capable of producing sounds. And those who already speak more than one language are also capable of code-switching, so switching between languages. And ELF-informed language teaching starts from these capabilities, as diverse as they might be for each student. This shifts the focus from the subject English to the individual and their potential, to what they bring to the classroom.

Realizing each students' personal potential and validating their individual capabilities can contribute to successful potential development in language classrooms. The promotion of giftedness has to start from the person, the individual, and ELF-informed language teaching can contribute to potential development. 


\section{References}

Bachman, L. F., \& Palmer, A. S. (1982). The construct validation of some components of communicative proficiency. Tesol Quarterly, 16(4), 449-465.

Björkman, B. (2014). An analysis of polyadic English as a lingua franca (ELF) speech? A communicative strategies framework. Journal of Pragmatics, 66, 122-138.

Canale, M., \& Swain, M. (1980). Theoretical bases of communicative approaches to second language teaching and testing. Applied Linguistics, 1(1), 1-47.

Commission of the European Communities. (2012). Europeans and their languages (Special Eurobarometer 386). Brussels: European Commission.

Council of Europe. (2001). Common European framework of reference for languages: Learning, teaching, assessment. Cambridge, England: Cambridge University Press.

Council of Europe. (2016). CEFR illustrative descriptors (Extended version 2016). Strasbourg, France: Council of Europe.

European Court of Auditors. (2016). Misused English words and expressions in EU publications. Retrieved from https://www.eca.europa.eu/Other\% 2opublications/EN_TERMINOLOGY_PUBLICATION/EN_TERMINOLOGY _PUBLICATION.pdf

Gardner, H. (1991). Abschied vom IQ: Die Rahmentheorie der unterschiedlichen Intelligenzen [Farewell to the IQ: The frame theory of different intelligences]. Stuttgart, Germany: Klett-Cotta.

Grabner, R. H. (2016, October). Systemische Begabungs und Exzellenzförderung: Schlussfolgerungen aus der Intelligenz-, Expertise- und Lehr-Lernforschung [Systemic gift and excellence promotion: Conclusions from intelligence, expertise and teaching-learning research]. Paper presented at the ÖZBF Kongress, Salzburg, Austria.

Heller, K. (2011). Hochbegabung im Kindes- und Jugendalter [Giftedness in childhood and adolescence]. Göttingen, Germany: Hogrefe.

Hymes, D. H. (1972). On communicative competence. In J. B. Pride \& J. Holmes (Eds.), Sociolinguistics: Selected readings (pp. 269-293). Harmondsworth, England: Penguin.

Jenkins, J. (2000). The phonology of English as an international language: New models, new norms, new goals. Oxford, England: Oxford University Press.

Jenkins, J., Cogo, A., \& Dewey, M. (2011). Review of developments in research into English as a Lingua Franca. Language Teaching, 44(3), 281-315.

Jørgensen, J. N. (2008). Polylingual languaging around and among children and adolescents. International Journal of Multilingualism, 5(3), 161-176.

Kachru, B. (1992). The other tongue: English across cultures. Champaign, IL: University of Illinois Press.

Kirkpatrick, A. (2007). The communicative strategies of ASEAN speakers of English as a lingua franca. In D. Prescott (Ed.), English in Southeast Asia: Va- 
rieties, literacies and literatures (pp. 118-137). Cambridge, England: Cambridge Scholars Publishing.

Mönks, F.S. (1992). Ein interaktionalistisches Modell der Hochbegabung [An interactionist model of giftedness]. In E. A. Hany \& H. Nickel (Eds.), Begabung und Hochbegabung: Theoretische Konzepte, empirische Befunde und praktische Konsequenzen [Giftedness and giftedness: Theoretical concepts, empirical findings and practical consequences] (pp. 17-22). Bern, Germany: Huber.

Renzulli, J. S. (1986). The three ring conception of giftedness: A developmental model for creative productivity. In R. J. Sternberg \& J. E. Davidson (Eds.), Conception of giftedness (pp. 53-92). Cambridge, England: Cambridge University Press.

Roth, H. (1952). Begabung und Begaben [Talent and gifts]. Sammlung, 7, 395407.

Seidlhofer, B. (2011). Understanding English as a lingua franca. Oxford, England: Oxford University Press.

Weigand, G. (2016). Modul I eVOCATIOn (Unpublished teaching materials). Vienna University, Vienna, Austria.

Widdowson, H. (2003). Defining Issues in English language teaching. Oxford, England: Oxford University Press. 


\title{
Contributors of High Achieving Students' Linguistic Competence
}

\author{
Theodoros P. Kokkinos
}

University of Thessaly, Greece

theokokkinos@yahoo.gr

\author{
Aikaterini D. Gari \\ National and Kapodistrian University of Athens, Greece \\ agari@psych.uoa.gr
}

Lavrentios G. Dellassoudas

National and Kapodistrian University of Athens, Greece lavdellas@ppp.uoa.gr

This study explores the contribution of linguistic, creativity and motivation features on high achieving students' language performance in secondary education. The sample $(N=87)$ was selected on the basis of students' excellent performance in a national highly competitive formal language exam. 44 high school teachers in 25 schools of the broader area of Athens participated in a structured interview process rating these students' features on 6 Likert type questions through a 5-point scale. A three factor model came up but in a hierarchical multiple regression analysis these features were not found to contribute significantly to the sample students' language performance.

Keywords: high achieving students, creativity, motivation, writing, secondary education

\section{Introduction}

In many countries, professional educators are concerned about raising the quality of teaching and learning in the school system, especially in terms of the mother tongue writing competence. In Greece there is particular concern about the quality of Language Arts teaching, as it is considered a basic discipline that leads to Higher Education through a Pan-Hellenic Exams procedure, a kind of highly competitive, state exams for enrolment in the state Greek universities. These Exams are being organized each year by the Ministry of Education and are a prerequisite in order for a student to enter Higher Education. They are placed at the end of secondary educations' last year (12th year), happening at the same time and having the same content on a national level. The common discipline in which all students are examined, regardless of the study orientation they have chosen (Humanities, Science or Technology), is Language Arts. Particularly, students are required to answer some 
reading comprehension questions based on a given text, to summarize it, answer vocabulary drills and write their own argumentative text on a given subject correlated to the given texts' thematic core. So, it can be understood that these Exams are a highly demanding and competitive procedure that trigger students' motivation. The afore mentioned educators' concern though is evidenced by the Exams' results in Language Arts, in which students are consistently being placed at the lower end of the achievement range (only around $2 \%$ of the participants excel). Therefore, these high achieving students form each year a marginal group of students, a true very low percentage, among Greek students at this educational level. Thus, the investigation of these students' linguistic features and their relationship to a specific group of features, such as motivation, that is triggered through the particular examination process and creativity, might further our understanding of the processes that may lead not only to these students' effective support but also to the whole system's excellence boost.

\section{Creativity Features of High Ability Students}

Current literature indicates that creativity is a basic feature of high ability students (Miller, 2012). Numerous research approaches argue that the identification of divergent thinking, as a reliable indicator of an individuals' creative potential, is based on the evaluation of a person's interaction with a problem (Klausen, 2010; Sternberg, 2008). Specifically, the degree of fluency, originality, elaboration, and flexibility of one's ideas during the successive phases of finding and identifying the problem, hypothesizing and organizing a solution plan, and finally sharing the results, are assessed and evaluated (Treffinger \& Isaksen, 2005). Elaborating on this concept, creative thinking seems to be the ability to see things in new and original ways, to learn from experience and relating it to new situations, to think in unconventional and unique ways, to use non-traditional approaches to solving problems, and creating something unique and original.

A considerable number of research studies move a step further as they try to correlate the writing process with creativity in the school context. It has been argued that students' positive attitudes towards writing show a positive correlation with creativity, especially with the students' ability of elaboration (enrichment of the original thematic core with details) (Wang, 2012). Also, it has been found that during the writing process, the skills that are activated such as the freedom and ability to communicate ideas, as well as thinking, remembering, reasoning and exploring, are also positively and significantly correlated with creative thinking (McVey, 2008; Sturgell, 2008). As 
regards high ability students, it has been suggested that creativity is related to their writing abilities in the sense that some of the features relevant to the writing ability - such as free communication of ideas, the consideration of the human individual and self-disclosure - somehow overlap with those features which are expected to enhance creativity (Sak, 2004).

Specific creative behaviours in the classroom can be correlated with high ability students' (a) personality and motivation features, such as autonomy, nonconformity, risk taking, high degree of curiosity and self-discovery, developed and refined sense of humour (Fasko, 2001; Shade, 1999), tolerance to ambiguity, willingness, perseverance and task commitment (Beghetto, 2005), (b) social factors such as abundant resources and the ability of communicating ideas (Amabile \& Pillemer, 2012), and (c) data processing procedures such as the use of the conquered cognitive data for creating and expanding ideas.

Gender differences in creative thinking abilities are generally of great interest (Lau \& Cheung, 2015). Current literature offers contradictory findings on males' and females' use of their creative thinking skills (Hong, Peng, O'Neil, \& $\mathrm{Wu}$, 2013). Some empirical studies have indicated that females tend to have overall higher creativity scores than men (Awamleh, Al Farah, \& El-Zraigat, 2012; Hong et al., 2013). Studies usually reveal that there are no significant differences between males and females as far as originality subtests are concerned (Bart, Hokanson, Sahin, \& Abdelsamea, 2015; Hong et al., 2013). Also, within the Greek educational system, divergent thinking among Greek primary students was studied via teachers' ratings and students' divergent thinking tasks focusing on linguistic expression. The divergent thinking task scores results indicated that female students scored higher in the subtests of fluency and flexibility, than the male students did (Kousoulas \& Mega, 2009). Furthermore, a study comparing secondary high and low achievers' creativity features, indicated that girls scored higher than boys (Anwar, Shamim-urRasool, \& Haq, 2012).

\section{Motivation Features of High Ability Students}

Academic intrinsic motivation is demonstrated generally by enjoyment of learning, curiosity, persistence, and the ability to learn challenging or difficult tasks (Gottfried, Marcoulides, Gottfried, \& Oliver, 2009). Furthermore, there are studies relating academic intrinsic motivation to academic achievement. Gottfried \& Gottfried (2004) for example have demonstrated that academic intrinsic motivation was a significant positive predictor of achievement beyond the variance attributable to $I Q$, with higher motivation predicting higher achievement. In brief, they found that children with higher 
academic intrinsic motivation tend to have significantly higher achievement, less anxiety, less extrinsic motivation, and higher intellectual performance. Also, according to other studies, high academic achievement is attributed to the combination of high ability and strong student effort (Street, 2001), since it implies the implementation of strong strategies concerning selfregulation, an indicator of strong intrinsic motivation (Tirri, 2010). Indeed, other studies also suggest that strong motivation of high ability students seems to come from features such as a high degree of personal interest and attribution of high value to school work, the pursuit of realistic objectives, perseverance in solving demanding tasks, a high degree of task commitment and responsibility (Lashaway-Bokina, 2000; Siegle \& McCoach, 2005). Moreover, a study focusing on high achieving students, found that gifted high achievers expressed higher levels of motivation than non-high achievers. At the same time, high achievers perceived positively a classroom structure that provides tasks with a focus on learning and more autonomy (Lüftenegger et al., 2015).

As regards gender differences, related research has found that teachers seem to consider that students with the strongest intrinsic motivation are of the female gender (Lashaway-Bokina, 2000), since it is widely held that girls show stronger task commitment and responsibility (Lupart, Cannon, \& Telfer, 2004). There are also some research findings concerning low motivation of high ability students within the Greek educational system (Gari, Kalantzi-Azizi, \& Mylonas, 2000; Theodoridou \& Davazoglou, 2006; Zbainos \& Kyritsi, 2011), but they don't focus on the relationship between motivation and domain-specific features such as creativity and linguistic traits.

\section{Linguistic Features of High Ability Students}

According to related literature, a significant diversification of high ability students' linguistic features from their typical peers can be observed not only at the cognitive linguistic infrastructure but also at the differentiation of their language choices and their overall communicative ability.

High ability students' main linguistic features can be summarized in specific areas of language competence, such as the vocabulary/grammatical competence where there is not only a greater range but also a faster introduction of new stimuli to these students' mental infrastructure compared to their peers. Also, in speech reception high ability students are characterized by a stronger ability in both bottom-up and top-down reading processes. In bottom-up reading processes, namely decoding and understanding the meaning of words and sentences, these students present a higher level of 
speed and effectiveness in comprehending textual information as well as nuances and allusions. Regarding the top-down reading processes (the use of the students' knowledge base for a text's comprehension and interpretation) high ability students are strongly interested in extracting information from text of increased difficulty, indicate broader skills in maintaining structured information in long term memory and present greater speed in activating linguistic representation from long-term to functional memory. Moreover, they show stronger ability in correlating stored with incoming information during textual processing, while showing an increased level of metacognitive awareness of the processes used during the recovery and use of information (Vosslamber, 2002).

As regards text production, high ability students seem to prefer producing text through the use of higher-order processes such as analysis, synthesis and evaluation. Moreover, their writing demonstrates fluency, speech accuracy and adaptability to the communicative situation, as well as an appropriate use of a developed sense of humour and satire e.g., puns and language games (Decker-Collins \& Parkhurst, 1996). Such a set of abilities usually results in a more efficient involvement in meaning making and critical literacy processes (Hoh, 2005). Significant differences favouring girls have been found in their competence during the writing process (Swiatek, 2005) as well as their overall higher academic performance in Language Arts discipline (OlszewskiKubilius \& Lee, 2011).

\section{Current Study's Rationale}

It can be understood by the research findings described previously, that there is a considerable amount of empirical research focusing on high ability and gifted students' creativity, motivation and linguistic features as well as their relationship. It should be mentioned though that gifted students might not demonstrate high academic achievement, making the exploration of these relationships difficult. Also, high achieving students might not be gifted in any way.

The majority of the studies focusing on high achievers, on the other hand, do not focus systematically on such relationships as they investigate specific aspects of these students' personality and school behaviour e.g. learning styles and school strengths (Salmela \& Uusiautti, 2015; Stewart, 1981), motivation (Dunn \& Price, 1980; Lüftenegger et al., 2015) or psychological traits such as self confidence (Ablard, 1997) and social/emotional skills (Bain \& Bell, 2004). So, they cannot form a solid theoretical framework, on which researchers can elaborate. Also, the majority of the studies focus on Science (Stott \& Hobden, 
2016) or Mathematics (Lüftenegger et al., 2015), neglecting Humanities and Social Sciences. Thus, it seems that there is a lack of research for Language Arts and specifically writing/text production, especially if the significance of this discipline for the students' further studies and future development is taken under serious consideration. Moreover, the relationship among linguistic features of high achievers with other domains that have already been researched independently, such as motivation and creativity, has not been yet investigated.

Therefore, the purpose of this study is to investigate the writing competence and specifically the text production features of secondary high achieving students in relation to their creativity and motivation features in order for possible differences between gifted and high achieving students to emerge.

\section{Method}

The purpose of this study is to investigate linguistic features of secondary high achieving students (focusing on text production) in relation to their creativity and motivation features. Furthermore, a sub-objective of the study is to gain insight on possible differences between gifted and high achieving students' features.

Therefore, the researchers hypothesize that:

1. High achieving students' text production features will be highly correlated to motivation and creativity.

2. Motivation will be the stronger contributor to high achieving students' overall language performance, compared with creativity and linguistic features.

3. Based on previous research findings, significant differences will be found in favour of girls in all three item groups.

\section{Participants}

A student sample was selected for the purpose of this study on the basis of very high performance in a formal evaluation of linguistic features (Ngoi \& Vondracek, 2004). Taking into consideration that in Greece there are no formal criteria yet on identifying excellence in abilities for the state school students (Gari, 2007), the procedure of choice has been through the Pan-Hellenic Exams, in which the particular student sample had excellent performance. It is a formal irreproachable evaluation process that happens simultaneously for all students on a national level, it is highly competitive and, therefore, triggers students' motivation. Moreover, it is highly demanding, as it requires 
the answering of a range of activities (summarizing reading comprehension, vocabulary and grammatical drills, text production). Specifically, in the text production activity, skills/features such as speech accuracy and adaptability to the communicative situation are positively and highly valued for the overall scoring.

Via access to the score tables through proper licensing procedures from the relevant authority (Ministry of Education), the teachers that taught during the last year of secondary education particular students who excelled, were approached. It was not feasible for the students to be traced by the researchers, as personal information for them, apart from their exam code number, could not be obtained due to protection by the Data Protection Law.

The student sample selection was performed by simple random sampling from the official score tables. The research process involved 44 secondary school teachers with whom a structured interview process was conducted investigating the linguistic features of 87 students in total $(N=87)$, enrolled in 25 general public, public experimental and private schools from all educational regions of Attica, all around the capital city. The majority of the sample's students was females (88.5\%) and had followed the TheoreticalHumanitarian study orientation (51.8\%), while students of Science and Technology study orientation were of $34.1 \%$ and $14.1 \%$, respectively.

\section{Instrument}

An interview guide, formed by the researchers, was administered to the participating teachers during the structured interview process, who were asked to rate the presence of specific linguistic, motivation and creativity features that they observed throughout the year in their high achieving students based on a five-point Likert-type scale where 1 'never' and 5 'al ways.' In the linguistic features item group, Vocabulary Level, Interdisciplinary Connections, Extracurricular Reading, Repeated Text Reviewing, Request for Advanced Reading Resources, Speech Adaptability, Speech Accuracy, Speed of Textual Comprehension and Depth of Textual Comprehension were selected from a broader set of linguistic features attributable to linguistically talented students by related research. As regards creativity features Sense of Humour, Response to Higher Order Questioning, Originality of Responses, Restless Spirit, Nonconformity, Fear of Being Different, and Attracting Attention were placed in the instrument. Motivation features contained Task Commitment, Independent Studying, Perseverance and Strong Interest. Part of the items for the creativity (Originality of Responses) and motivation (Task Commitment) were based on the Scales for Rating the Behavioural Characteristics 
of Superior Students (SRBCSS) (Renzulli, Siegle, Reis, Gavin, \& Reed, 2009; Renzulli, Smith, White, Callahan, \& Hartman, 2002).

During a pilot study, ten interviews with participants from schools of almost the whole range of Attica were conducted. Internal consistency of the instrument's items found to be at a very high level (Cronbach's $\alpha=0.90$ ) indicating high reliability.

\section{Results}

\section{Descriptives}

The highest mean was noted in the variable of Speech Accuracy $(M=4.5$, $S D=.99$ ), followed by Speech Adaptability to the Communicative Situation $(M=4.4, S D=1.26)$. Moreover, the means were high for the variable of Task Commitment $(M=4.3, S D=1.43)$ and the responsiveness to Problem Solving Questions $(M=4.0, S D=1.56)$. On the contrary, the Originality of Responses $(M=3.5, S D=1.86)$ and Non Conformity $(M=2.0, S D=1.78)$ had the lowest means.

\section{Factor Analysis}

In order to explore the correlations further, an exploratory factor analysis with a Principal Components method was conducted. Prior to this, the factorability of the 18 items was examined. Firstly, 15 of the 18 items correlated at least 0.30 with at least one other item, suggesting reasonable factorability. Secondly, the Kaiser-Meyer-Olkin measure of Sampling Adequacy was 0.758 , above the recommended value of 0.6 , and Bartlett's Test of Sphericity was significant $\left(\chi^{2}(153)=640.646, p<0.001\right)$. Initially, a five factor solution was suggested by a Principal Components Analysis with direct oblimin rotation, explaining $64.45 \%$ of total variance. However, three cross-loadings appeared on the factor loading matrix. Thus, a three factor solution, which explained $51.33 \%$ of the variance, was preferred because of its previous theoretical support, the 'levelling off' of eigenvalues on the scree plot after three factors, and the difficulty of interpreting the fourth and fifth factors. As can be seen in Table 1, which presents the factor loading matrix for the final three factor solution, the factor labels suited the extracted factors and correspond to the three major item groups (linguistic, creativity, motivation) investigated in the current study. Internal consistency for each of the scales was examined using Cronbach's alpha. The alphas were satisfactory, 0.818 for linguistic features ( 8 items), 0.72 for creativity ( 6 items), and 0.62 for motivation ( 3 items). No substantial increases in alpha for any of the scales could have been achieved by eliminating more items. 
The first factor was labelled 'Linguistic Features' due to the high loadings by the following items: Speed of Textual Comprehension, Depth of Textual Comprehension, Speech Adaptability, Strong Interest in the Syllabus, Speech Accuracy, Perseverance, Extracurricular Reading, Vocabulary Level and explained $30.2 \%$ of the variance.

The second factor yielded by the analysis was labelled 'Creativity Features.' This factor was labelled as such due to the high loadings by the following items: Restless Spirit, Sense of Humour, Nonconformity, Originality of Responses, Responsiveness to Higher Order Questioning and Interdisciplinary Connections. The variance explained by this factor was $12.2 \%$.

The third factor was labelled 'Motivation Features' due to the high loadings by items such as: Repeated Text Reviewing, Request for Advanced Reading Resources and Task Commitment. This factor explained $8.9 \%$ of the variance. The communalities of the variables are relatively high, especially for Speed of Textual Comprehension (0.710), Depth of Textual Comprehension (0.669), and Task Commitment (0.658), suggesting that almost 70\% of speech reception and task commitment items variability is being accounted for by the three factor model. This may indicate that these variables are strongly related with each other and perhaps an underlying pattern connecting speech reception and motivation is being suggested.

Overall, these analyses indicated that three distinct factors were underlying the sample's students' characteristics items and that these factors were moderately internally consistent. These three tendencies are not independent of one another.

\section{Mean differences by Gender, Study Orientation and School Type}

Prior to comparing means, the assumption of normality was tested and not satisfied for all variables in relation to gender, study orientation and school type (Shapiro-Wilk test was found significant for all variables). Homogeneity of variance was also tested by gender, study orientation and school type and was not satisfactory for Problem Solving Questioning $(F(14,72)=5.612$, $p<0.001)$, Originality of Responses $(F(14,72)=2.079, p<0.05)$, Non Conformity $(F(14,72)=1.944, p<0.05)$, Task Commitment $(F(14,72)=1.845, p<0.05)$, Speech Adaptability $(F(14,72)=2.634, p<0.05)$ and Speech Accuracy $(F(14$, 72) $=4.358, p<0.001$ ).

Therefore, due to the lack of homogeneity we proceeded with performing the non parametric Kruskal-Wallis $H$ test. Statistically different ranks by students' gender were observed between the two groups only in responsiveness to Problem Solving Questions in favour of boys $\left(\chi^{2}(1)=4.342, p<0.05\right.$, 
Table 1 Factor Loadings for Principal Components Analysis with Direct Oblimin Rotation

\begin{tabular}{lrrr}
\hline Components & $(1)$ & $(2)$ & $(3)$ \\
\hline Speed of Textual Comprehension & 0.844 & 0.073 & -0.222 \\
Depth of Textual Comprehension & 0.764 & 0.210 & -0.100 \\
Speech Adaptability & 0.617 & 0.143 & 0.198 \\
Strong Interest in the Syllabus & 0.599 & -0.202 & -0.086 \\
Speech Accuracy & 0.574 & 0.088 & 0.408 \\
Perseverance & 0.529 & -0.188 & 0.469 \\
Extracurricular Reading & 0.511 & 0.337 & -0.028 \\
Vocabulary Level & 0.490 & 0.356 & 0.272 \\
Independent Studying & 0.151 & 0.101 & 0.020 \\
Restless Spirit & 0.076 & 0.757 & 0.020 \\
Sense of Humour & 0.033 & 0.683 & -0.139 \\
Nonconformity & -0.175 & 0.617 & 0.147 \\
Originality of Responses & 0.050 & 0.599 & -0.078 \\
Responsiveness to Higher Order Questioning & 0.208 & 0.571 & 0.238 \\
Interdisciplinary Connections & 0.373 & 0.503 & -0.022 \\
Repeated Text Reviewing & -0.039 & -0.076 & 0.780 \\
Request for Advanced Reading Resources & -0.219 & 0.328 & 0.697 \\
Task Commitment & 0.526 & -0.292 & 0.532 \\
\hline
\end{tabular}

Notes Factors: (1) linguistic features (30.2\%), (2) creativity features (12.2\%), (3) motivation features (8.9\%).

$\left.\eta^{2}=0.05\right)$ and in Request for Advanced Reading Resources in favour of girls $\left(x^{2}(1)=5.162, p<0.05, \eta^{2}=0.06\right)$.

As far as school type is concerned statistically different mean ranks by school type (General Public, Public Experimental and Private) were observed between the three groups in responsiveness to Problem Solving Questions $\left(x^{2}(2)=6.326, p<0.05, \eta^{2}=0.07\right)$, in Non Conformity $\left(x^{2}(2)=6.881, p<0.05\right.$, $\left.\eta^{2}=0.08\right)$, in Strong Interest in the Syllabus $\left(x^{2}(2)=6.613, p<0.05, \eta^{2}=0.07\right)$ and in Extracurricular Reading $\left(x^{2}(2)=6.674, p<0.05, \eta^{2}=0.07\right)$. According to post hoc comparisons of the Kruskal-Wallis $H$, significant differences between students of general public and private schools were found in favour of private schools' students for responsiveness to Problem Solving Questions $\left(x^{2}(1)=4.425, p<0.05, \eta^{2}=0.059\right)$, Restless Spirit $\left(x^{2}(1)=4.134, p<0.05, \eta^{2}=\right.$ $0.05)$, Non Conformity $\left(x^{2}(1)=6.875, p<0.05, \eta^{2}=0.091\right)$ and Vocabulary Level $\left(x^{2}(1)=4.258, p<0.05, \eta^{2}=0.05\right)$. Additionally, between General Public and Public Experimental schools significant differences were found in favour of General Public school students' only for the Strong Interest in the Syllabus $\left(x^{2}(1)=5.887, p<0.05, \eta^{2}=0.07\right)$. 
Finally, in relation to study orientation (Humanities, Science, Technology) significant differences were found only for Vocabulary Level $\left(x^{2}(1)=6.173, p\right.$ $<0.05, \eta^{2}=0.07$ ). According to post hoc comparisons of the Kruskal-Wallis $H$, significant differences in favour of students of Humanities against those of Technology were found $\left(x^{2}(1)=6.129, p<0.05, \eta^{2}=0.01\right)$

\section{Correlations among Creativity, Motivation and Linguistic Features}

The strongest correlations across the three factors were found for the items of Vocabulary Level which was correlated to Problem Solving Questioning (Pearson $r=0.640, p<0.01$ ), Speech Adaptability was found to be strongly correlated to Perseverance (Pearson $r=0.623, p=0.000$ ). Moreover, Speech Accuracy was found to be correlated to the most creativity features as well as to motivation features such as Task Commitment (Pearson $r=0.526, p<0.01$ ). It should be mentioned that most of the creativity features are not correlated significantly to motivation features, while they have a positive significant correlation with linguistic features. So, it seems that there is a relationship mainly among motivation and linguistic features as well as creativity and linguistic features. Additionally, a multiple regression analysis was performed but did not return meaningful results. Therefore, further study is required in order for predictors of high language performance to be explored.

\section{Discussion}

The results of this study constitute a first exploratory approach to features correlated with motivation, creativity and linguistic competence levels of high achieving students in Greek secondary education. Also, the current study provides guidelines for assessing creativity and motivation in Language Arts, offering a deeper understanding between these two concepts for educators who must rate creativity and motivation in the classroom in order to support the linguistic needs of high ability students.

As regards the first research question, there is definitely a relationship among creativity and motivation to the linguistic features of high achieving students. The correlation matrix and the principal components analysis depicted that positive and significant correlations were found among the majority of the target items, suggesting that broad effect relationships emerge among these item groups to linguistic features. Thus, the initial hypothesis is confirmed. These findings indicate that creativity is related to high achieving students' writing abilities, as Sak (2004) found, but they also offer data that suggest a connection between their motivation and linguistic features, an aspect that has not been investigated before. 
As regards the second research question, namely the contribution of linguistic features, creativity and motivation to high achieving students' language performance, it seems that there is a relationship among these three factors that emerged from the current study but, overall, high language performance cannot be explained and predicted by linguistic, motivation and creativity features. This may happen mainly due to the fact that this performance is a specific 'forced' situation of prestige and 'power gaining' in order to get to higher education in the Greek educational system in which situation the student is expected to fulfil expectations of parents and of private teachers outside state education. This is combined with the high subjectivity of students' essay correction based on the students' conformation and memorization of specific successful writing 'recipes' commercially available. Therefore, a definitive answer to the second research question could not be given by the current study's results as the findings call for further study in order for these relationships to be generalized.

As regards the third research question, that significant differences would be found in favour of girls, it was verified only for Request for Advanced Reading Resources. Therefore, the initial hypothesis of significant gender differences in favour of girls in all three features groups should be rejected. This finding is in the same line with other findings that don't suggest an overall higher linguistic performance for girls (Olszewski-Kubilius \& Lee, 2011; Swiatek, 2005).

The differences found by school type in favour of private schools possibly suggests that maybe there is an influence by the teaching strategies and the overall educational climate and practices followed in Private Schools (e.g. enrichment groups, advanced research projects etc.). It seems that responsiveness to problem solving questioning emerges as a common differential element across two out of these three independent variables, possibly suggesting that it is a strong feature of high achieving students regardless of gender and specific curriculum that may derive by school type attendance.

It seems that high achieving students' linguistic, creativity and motivation features' relationship to linguistic performance partially resembles with that of high ability/gifted students. Task Commitment has already been found to be a significant factor of high abilities/giftedness (Lashaway-Bokina, 2000; Siegle \& McCoach, 2005) and the findings of the current study offer insight on the emergence of the same factor in high achieving students too.

Overall, the criteria for the effective Language Arts curriculum design concerning high achieving students' should not ignore the parameters of motivation and creative behaviour. Also, a need for a broader use of research 
projects emerges, which contribute to the activation and development of the students' research and problem solving skills.

\section{Limitations and Future Research}

The most important limitation of the current study is the fact that in Greece there are no formal/standardized assessment criteria yet on identifying high abilities and gifted characteristics/features (Gari, 2007), which would act as a control group. Such a comparison with a control group might contribute to the development of relevant research but also the formation of an overall supportive educational policy (e.g. development of curriculum differentiation parameters) extremely difficult. Also, the geographic dispersion and the sample size might limit the findings' generalization. Thus, changes in students' selection criterion and in the sample range may have had a significant influence on the results.

Future research should focus on determining the influence of specific factors (e.g. school culture) on high achieving students' creativity features. Also, a need for further investigation on the relationship of creativity to linguistic competence emerged in order for these relationship to be generalized. Finally, the findings of the current study call for a more thorough investigation on the contribution of motivation to high achieving students' writing competence.

\section{Acknowledgements}

This research was supported by the Greek State Scholarship Foundation to the first author.

\section{References}

Ablard, K. (1997). Self-perceptions and needs as a function of type of academic ability and gender. Roeper Review, 20, 110-115.

Amabile, T. M. \& Pillemer, J. (2012). Perspectives on the social psychology of creativity. Journal of Creative Behavior, 46(1), 3-15.

Anwar, M. N., Shamim-ur-Rasool, S., \& Haq, R. (2012). A comparison of creative thinking abilities of high and low achievers secondary school students. International Interdisciplinary Journal of Education, 1(1), 1-6.

Awamleh, H., Al Farah, Y., \& El-Zraigat, I. (2012). The level of creative abilities dimensions according to Torrance formal test (B) and their relationship with some variables (Sex, Age GPA). International Education Studies, 5(6), 138148.

Bain, S. K. \& Bell, S. M. (2004). Social self-concept, social attributions, and peer relationships in fourth, fifth, and sixth graders who are gifted compared to high achievers. Gifted Child Quarterly, 48(3), 167-178. 
Bart, W. M., Hokanson, B., Sahin, I., \& Abdelsamea, M. A. (2015). An investigation of the gender differences in creative thinking abilities among 8th and 11th grade students. Thinking Skills and Creativity, 17, 17-24.

Beghetto, R. A. (2005). Does assessment kill student creativity? The Educational Forum, 69, 254-263.

Decker-Collins, N. \& Parkhurst, L. (1996). The writing process: A tool for working with gifted students on the regular classroom. Roeper Review, 18(4), 277280.

Dunn, R. \& Price, G. E. (1980). The learning style characteristics of gifted students. Gifted Child Quarterly, 24(1), 33-36.

Fasko, D. (2001). Education and creativity. Creativity Research Journal, 13(3/4), 317-327.

Gari, A. (2007, May). Gifted Education in Greece. ECHA News, $21(1), 7$.

Gari, A., Kalantzi-Azizi, A., \& Mylonas, K. (2000). Adaptation and motivation of Greek gifted pupils: Exploring some influences of primary schooling. High Ability Studies, 11(1), 55-68.

Gottfried, A. E. \& Gottfried, A. W. (2004). Toward the development of a conceptualization of gifted motivation. Gifted Child Quarterly, 48(2), 121-132.

Gottfried, A. E., Marcoulides, G. A., Gottfried, A. W., \& Oliver, P. H. (2009). A latent curve model of parental motivational practices and developmental decline in math and science academic intrinsic motivation. Journal of Educational Psychology, 101, 729-739.

Hoh, P.-S. (2005). The linguistic advantage of the intellectually gifted child: An empirical study of spontaneous speech. Roeper Review, 27(3), 178-185.

Hong, E., Peng, Y., O'Neil, H. F., \& Wu, J. (2013). Domain-general and domainspecific creative-thinking tests: Effects of gender and item content on test performance. The Journal of Creative Behavior, 47(2), 89-105.

Klausen, S. H. (2010). The notion of creativity revisited: A philosophical perspective on creativity research. Creativity Research Journal, 22(4), 347-360.

Kousoulas, F. \& Mega, G. (2009). Students' divergent thinking and teachers' ratings of creativity. The Journal of Creative Behavior, 43(3), 209-222.

Lashaway-Bokina, N. (2000). Recognizing and nurturing intrinsic motivation: A cautionary tale. Roeper Review, 22(4), 225-227.

Lau, S. \& Cheung, P. C. (2015). A gender-fair look at variability in creativity: Growth in variability over a period versus gender comparison at a time point. Creativity Research Journal, 27(1), 87-95.

Lüftenegger, M., Kollmayer, M., Bergsmann, E., Jöstl, G., Spiel, C., \& Schober, B. (2015). Mathematically gifted students and high achievement: The role of motivation and classroom structure. High Ability Studies, 26(2), 227-243.

Lupart, J. L., Cannon, E., \& Telfer, J. A. (2004). Gender differences in adolescent academic achievement, interests, values and life-role expectations. High Ability Studies, 15(1), 25-42. 
McVey, D. (2008). Why all writing is creative writing. Innovations in Education \& Teaching International, 45(3), 289-294.

Miller, A. L. (2012). Conceptualizations of creativity: Comparing theories and models of giftedness. Roeper Review, 34(2), 94-103.

Ngoi, M. \& Vondracek, M. (2004). Working with gifted science students in a public high school environment: One school's approach. Journal of Advanced Academics, 15(4), 141-147.

Olszewski-Kubilius, P. \& Lee, S.-Y. (2011). Gender and other group differences in performance on off-level tests. Gifted Child Quarterly, 55(1), 54-73.

Renzulli, J. S., Smith, L. H., White, A. J., Callahan, C. M., Hartman,R. K., \& Westberg, K. L. (2002). Scales for rating the behavioral characteristics of superior students (Revised). Mansfield Center, CT: Creative Learning Press.

Renzulli, J. S., Siegle, D., Reis, S. M., Gavin, M. K., \& Reed, R. (2009). An investigation of the reliability and factor structure of four new Scales for Rating the Behavioural Characteristics of Superior Students. Journal of Advanced Academics, 21(1), 84-108.

Sak, U. (2004). About creativity, giftedness and teaching the creatively gifted in the classroom. Roeper Review, 26(4), 216-223.

Salmela, M. \& Uusiautti, S. (2015). A positive psychological viewpoint for success at school: 10 characteristic strengths of the Finnish high-achieving students. High Ability Studies, 26(1), 117-137.

Shade, R. A. (1999). Humour: A course of study for gifted learners. Gifted Child Today, 22(1), 46-49.

Siegle, D. \& McCoach, D. B. (2005). Making a difference: Motivating gifted students who are not achieving. Teaching Exceptional Children, 38(1), 22-27.

Sternberg, R. J. (2008). The concept of creativity: Prospects and paradigms. In R. J. Sternberg (Ed.), Handbook of creativity (11th ed., pp. 3-15). Cambridge, England: Cambridge University Press.

Stewart, E. D. (1981). Learning styles among gifted/talented students: Instructional technique preferences. Exceptional Children, 48(2), 134-138.

Stott, A. \& Hobden, P. A. (2016). Effective learning: A case study of the learning strategies used by a gifted high achiever in learning Science. Gifted Child Quarterly, 60(1), 63-74.

Street, P. (2001). The role of motivation to the academic achievement of gifted secondary students. Gifted Educational International, 15(2), 164-177.

Sturgell, I. (2008). Touchstone texts: Fertile ground for creativity. Reading Teacher, 61(5), 411-414.

Swiatek, M. A. (2005). Gifted students' self-perceptions of ability in specific subject domains: Factor structure and relationship with above-level test scores. Roeper Review, 27(2), 104-109.

Theodoridou, S. \& Davazoglou, A. (2006). Teachers' evaluation of gifted children's characteristics. Gifted and Talented International, 21, 72-76. 
Tirri, K. (2010). Motivation and giftedness. High Ability Studies, 21(2), 77-80.

Treffinger, D. J. \& Isaksen, S. G. (2005). Creative problem solving: The history, development, and implications for gifted education and talent development. Gifted Child Quarterly, 49(4), 342-353.

Vosslamber, A. (2002). Gifted readers: Who are they and how can they be served in the classroom? Gifted Child Today, 25(2), 14-20.

Wang, A. Y. (2012). Exploring the relationship of creative thinking to reading and writing. Thinking Skills and Creativity, 7(1), 38-47.

Zbainos, D. \& Kyritsi, A. (2011). Greek talented students' motivation: A qualitative analysis. Gifted and Talented International, 26(1-2), 131-142. 


\title{
Exploring Dutch Students' Implicit Theories of an Intelligent Person
}

\section{Trudie G. C. Malotaux-Christophersen}

Radboud University, The Netherlands

trudiemalotaux@gmail.com

\section{Sven A. C. Mathijssen}

Radboud University and Tilburg University, The Netherlands

s.mathijssen@ru.nl

\author{
Lianne Hoogeveen \\ Radboud University, The Netherlands \\ l.hoogeveen@ru.nl
}

Implicit theories of intelligence play a crucial role in our learning, influencing our observations, decisions and actions. Dutch (highly) able seventh grade students were asked to draw an intelligent person and to rate the presence of some characteristics. Cultural background, living area, programs followed at primary education, and gender were taken into account. Overall, an intelligent person was depicted as hardworking, persistent, and talented in Mathematics and Science. To monitor development in gifted education, a follow up study is recommended.

Keywords: implicit theories, intelligence, culture, gender, education, pictures

\section{Introduction}

Dutch boys statistically achieve more in science than Dutch girls, while in Finland, Slovenia and Turkey it is the other way around (OECD, 2011). Considering the countries that participated in PISA 2009, girls outperformed boys in 22 countries, whereas in 11 countries boys outperformed girls. In the other 33 countries, there was no significant difference between the genders (OECD, 2011). As there is no biological explanation for these differences, implicit theories might be one of the factors that play a role here (Chiao, 2009; Han \& Northoff, 2008; Krabbendam, 2012; Nosek et al., 2009).

Sternberg, Conway, Ketron, and Bernstein (1981) defined implicit theories as personal constructions about a specific phenomenon, residing in the mind of an individual. According to Sternberg (2004), nothing has as much impact on actual life and practices as implicit theories. Though implicit theories are not bound to one domain, this study is concentrated on implicit theories of intelligence. Often, we are not aware of our own implicit theories. Neither do we realize they differ from others. They are rooted in cul- 
ture, and arise from unconscious functions of the brain (Blakemore, Wolpert, \& Frith, 2000; Fletcher, \& Frith, 2009; Krabbendam, 2012). Han and Northoff (2008), and Chiao (2009) for example, demonstrated a correlation between differences in cultural background, and the neuronal activity that underlies cognitive functions. This correlation between culture and neuronal activity is partially a consequence of the working of the brain while observing and processing information (Blakemore, Wolpert, \& Frith, 2000; Fletcher, \& Frith, 2009; Krabbendam, 2012). Observations, for instance, are based on presumptions (Blakemore, Wolpert, \& Frith, 2000; Knoop, 2015; Krabbendam, 2012). The brain, based on acquired knowledge rooted in structured habits of a culture, hypothesizes and predicts the chance and impact of an observation, in order to decide to pay attention or not. The final perceived experience is a combination of this prediction and the real observation (Blakemore, Wolpert \& Frith, 2000; Fletcher \& Frith, 2009; Knoop, 2015; Krabbendam 2012). In social interaction, the brain acts similarly, continuously hypothesizing and predicting the behaviour of others. According to this prediction, behaviour will be adjusted (Delgado, Frank, \& Phelps, 2006; Frith \& Frith, 2010). This process of predicting and adjusting, though it is occurring most of the times unconsciously, leads to implicit messages, and builds implicit theories (Krabbendam, 2012).

Sometimes the influence of implicit theories can be rather negative. Research shows that self-related implicit theories of intelligence can contain dysfunctional beliefs concerning an individual's own potential actions and abilities (Burkley, Burkley, Parker, \& Sterner, 2009; Chany, Burke, \& Burkley, 2011; Dweck, Chiu, \& Hong, 1995; Ommundsen, 2001; Stoeger, 2009; Ziegler, Vialle, \& Wimmer, 2013). These beliefs can greatly influence a student's selfregulated learning as they influence self-efficacy, motivation, willingness to take risks or to try new strategies, attributions, and, as a consequence of this, willingness to work hard and put effort in learning (Zimmerman, 2000, 2002).

Dweck et al. (1995) found an important correlation between reactions to problems, difficulties, setbacks or danger, and implicit theories. Those thinking that characteristics of a person are incremental tend to focus on analysing a problematical situation and taking action, while those believing those characteristics are an entity, tend to helplessness and blaming others. Concerning intelligence, Dweck (2006) found that those who believe that intelligence is not fixed, but malleable (a growth mind-set) are inclined to put more effort into learning. Facing setbacks, they will try new strategies, work even harder, and persist to reach their goal. Those who believe that intelligence is fixed (a fixed mind-set), are inclined to give up, thinking they lack the intelligence to 
reach their goal. They tend to attribute negative outcomes to others, in order to protect their image and own self-worth.

Sternberg $(2002,2007)$ mentioned the impact of cultural context on implicit theories, especially concepts of intelligence. Some cultures, for example, do not pay much attention to conventional academic knowledge. Their concept of intelligence focuses more on respect, initiative, or practical and social skills.

Although every individual culture has its own characteristics, there are quite significant differences found in implicit theories between Asian collectivistic and Western individualistic cultures. Neihart (2014) pointed out that in Asian collectivist societies the 'successful learner' - scoring well, but avoiding challenges, therefore never reaching his/her potential - (Neihart \& Betts, 2010) does not exist at all. Asian students cannot allow themselves to be complacent, according to Neihart. Having to fulfil their social obligations and honour their parents, they have strong social reasons to achieve highly (Li, 2002). One might expect that social pressure leads only to extrinsic motivation, but Chen et al. (2009) argued that goals based on social expectations do not reflect a lower form of motivation. The strong association between self and their social roles furthered their intrinsic motivation. Another stimulating effect on learning is the attitude of the parents towards talent. Law (2009) found that, in Hong Kong, parents attribute success to working hard, effort, and the use of effective learning strategies, not to talent. Such an attitude corresponds with a growth mind-set (Dweck, 2006).

Knowing the impact of culture on implicit theories, a closer look at Dutch behaviour might be interesting. In the Netherlands, there is a popular saying - 'Just act normal, you're acting crazy enough as you do!' Is this saying inadvertently influencing our students to avoid excellence? Another Dutch saying, - 'Do not stand out from the crowd' - depicts the Dutch, though having high regard for talented sportsmen and pop musicians, somehow do not appreciate others showing off their talents. Those who do are, in these instances, quite often seen as being arrogant instead.

Boekaerts (2003) investigated adolescence in Dutch culture. When asked to make statements of deep personal desires, students mentioned: 'I want to make the grade, I want to get a part time job, I want to be a happy person, I want my peers to like me, I want to be treated fairly, and I want to go out with peers' (p. 112). When asked about what they strongly wished to avoid, they mentioned, 'I want to avoid being a nerd, I want to avoid humiliation, and I want to avoid self-blame' (p. 112). Observantly, these young people were putting a lot of effort into social life, image, and a job, ultimately having little 
attention left for school (Boekaerts, 2003). Given that Dutch adolescents put such an effort into building their image, discovering their implicit theories of an intelligent person is of great importance. As long as they consider an intelligent person to be a nerd, any intervention will be counteracted as, according to Ziegler et al. (2013), learning activities are rejected in an avoidance actiotope.

Theoretically, a culture can be seen as a constellation of structured habits (Roepstorff, Niewohner, \& Beck, 2010). As these structured habits are the input for our predictions, this might also be an opportunity for interventions (Krabbendam, 2012).

The Dutch government, having ascertained that Dutch highly able students do not perform as well as expected, while those deemed less intelligent scored relatively well (Kordes, Bolsino, Limpens, \& Stolwijk, 2013; Segers, \& Hoogeveen, 2012), decided to focus on the education of the highly-able, launching stimulating programs at primary education levels, and continuing them at secondary education levels (Ministerie van Onderwijs, Cultuur en Wetenschap, 2014). It would be interesting to know if this approach influences implicit theories of the students.

There have not been many studies considering implicit theories of an intelligent person. There are, however, more studies about implicit theories of a scientist, and they have a much longer history of research (Schibeci, 2006). Inspired by Goodenough who started to use pictures to assess intelligence in 1926 (Klepsch \& Logie, 1982), and by Mead and Metraux (1957), who investigated the image of a scientist, Chambers (1983) developed the Draw-aScientist test (herein after called DAST). The following indicators were determined in advance: lab coat, glasses, facial grow of hair, instruments and laboratory equipment, books, technology, and formulae. Although Chambers initially used this test to classify children according to socio-economic categories, principles of this test were used to only assess the image of a scientist (Schibeci, 2006), often in a cross-cultural setting (e.g. Manabu, 2002; Picker \& Berry, 2000; Rubin, \& Cohen, 2003). Pictures are often used to reveal concepts of thinking that are hidden from other procedures, being worth a thousand words (Räty, Komulainen, Skorokhova, Kolesnikov, \& Hämäläinen, 2010).

Räty and Snellman (1997) did investigate implicit theories of an intelligent person in Russia. They asked students to draw an ordinary as well as an intelligent person. An interesting finding was that students tended draw an intelligent person as an adult, often male. An ordinary person they tended to draw in their own age and gender. The boys tended to draw an adult male with a high social status involved in a mental-cognitive activity. The girls' 
pictures showed more variety; there was no dominant stereotype detected. They drew men as well as women; not all women were drawn as an adult. In another study, Räty et al. (2010) compared images of intelligence in Finland with images of intelligence in Russia. Children were asked to draw pictures of an intelligent and of an ordinary pupil. They often pictured an intelligent pupil with glasses. The Russian boys and girls emphasized excellent grades and positive class activities in their pictures of intelligent pupils. Finnish participants tended to stress equality between ordinary and intelligent pupils. Often, the only difference between an ordinary pupil and an intelligent pupil were glasses.

Pictures provide important clues, but according to Schibeci and Lee (2003), pictures alone are not sufficient as a research tool. Aljughaiman et al. (2012) investigated and compared implicit theories of an intelligent person in Kenya and in Germany. They suggested that adolescents have differentiated perceptions of characteristics accompanying an intelligent person. To explore their assumption, students were first asked to draw an intelligent person within five minutes and afterwards, they had the opportunity to give more information in a questionnaire. The participants were seventh graders. As in the research of Räty and Snellman (1997), they all tended to draw an intelligent person as a grown up. A majority of the Germans pictured a male. In Kenya about half of the participants drew a male. Working hard was conceived as an important characteristic of an intelligent person, ranked first by both cultures. Interesting was the difference in sociability and popularity, regarded of more importance by the Kenyan participants (Aljughaiman et al., 2012). Aljughaiman et al. concluded that students have different implicit theories of intelligence and they recommended a cross-cultural, longitudinal, focused investigation of relationships between individual theories of intelligence and learning behaviour among gifted students.

Dutch prototypical views of an intelligent person have not been investigated yet. Realizing the impact of implicit theories on learning (Burkley et al., 2009; Chany et al., 2011; Dweck et al., 1995; Ommundsen, 2001; Stoeger, 2009; Ziegler et al., 2013), Dutch students' implicit theories of an intelligent person were examined. The research of Aljughaiman et al. (2012) was followed in order to detect what characteristics and talents Dutch students attribute to an intelligent person.

There are differences between Germany and the Netherlands, but both cultures are western and individualistic. Although the rating of 'hardworking' could differ - the Dutch consider the Germans as being more disciplined (Paul, 2005) - not much difference in attributions between Dutch and Ger- 
man data (Aljughaiman et al., 2012) was expected, except the rating of artistic talents. Compared to neighbouring countries, Dutch education in arts is very poor (De Vreede, 2015; Schutgens, 2015). Research shows a positive influence of arts on economic profit (Schutgens, 2015; De Vreede, 2015), on learning and on the development of 21st century competences (Bilhartz, Bruhn, \& Olsen, 2000; Elfland, 2002; Ho, Cheung, \& Chan, 2003; Hetland \& Winner, 2004; Hetland, 2008; Bolduc, 2009; Buys \& Miller, 2009; Eisner, 2009; Southgate \& Roscigno,2009; Belfiore \& Bennet, 2010; Hallam, 2010; Rapp-Paglizzi, Stewart, \& Rowe, 2011; Van Heusden, 2012). However, the Dutch government tends to regard arts as a luxury (Marlet, Laverman \& Poort, 2007).

To detect impeding presumptions, differences in implicit theories between boys and girls were examined. Based on the research of Kordes et al. (2013), a lower rating of 'talented in mathematics and sciences' was expected, if attributed to a female picture. Considering an intelligent person to be a nerd, while fearing to be regarded as a nerd themselves (Boekaerts, 2003), might be another impeding presumption, having a negative influence on learning (Chany et al., 2011; Burkley et al., 2009; Dweck et al., 1995; Ommundsen, 2001; Stoeger, 2009). Students who consider an intelligent person to be a nerd, were expected to rate social skills low, and to draw a person wearing glasses, an indispensable part of the stereotype of a nerd (Leder, Forster, \& Gerger, 2011).

As programs launched to improve gifted education at primary schools differ, differences in implicit theories of an intelligent person were expected. Differences in implicit theories of an intelligent person between students living in the city, and students living in rural areas of the Netherlands were investigated as well. Students living in rural areas, where life is more often influenced by values of the Bible (Becker \& De Hart, 2006) and where less distraction is available, might consider an intelligent person to be hard working and persistent, a good habit according to the Bible.

Differences in implicit theories of an intelligent person between those students who speak Dutch or English at home, and those speaking (partly) another language were investigated as well. Negative role stereotypes concerning those speaking another language at home were expected. According to Trommelen (2001), the Dutch consider people with another (nonwestern) cultural background less intelligent. Therefore, these students were expected to envision an intelligent person as a European and to regard social skills as a part of intelligence (Sternberg, 2007) as the majority of those speaking another language at home, came from collectivistic societies.

Finally, recognition of indicators of the DAST (Chambers, 1983) in the pic- 
Table 1 Geographical Distribution of the Dutch Population and of the Participants

\begin{tabular}{lllll}
\hline Region & Sample size (\%) & $n$ & City & Rural area \\
\hline West & 47 & 101 & Amsterdam & Schiedam \\
East & 21 & 40 & Almere & Harderwijk \\
North & 10 & 29 & Meppel & \\
South & 22 & 54 & Eindhoven & Weert \\
\hline
\end{tabular}

Notes Based on data from http://statline.cbs.nl/Statweb/.

tures were expected. To summarize, the objective of this research was to investigate Dutch students' implicit theories of an intelligent person, focusing on differences in gender, former primary education, geographical circumstances and language spoken at home.

\section{Method}

\section{Participants}

Out of 11.436 students attending the first year of Gymnasium or VWO+ (highest level in Dutch secondary education, comparable to seventh grade in the UK or US, see http://statline.cbs.nl/Statweb/) in 2014-2015, 225 (1.97\%) participants were selected. The mean age of the participants (120 boys and 101 girls) was 12 years and 2 months $(S D=0.64)$. The data of eight participants were excluded from the quantitative analyses concerning gender. Four because the participants did not state their gender, and four because the gender of the pictures could not be detected, as they drew both male and female pictures or a creature being half male, half female. At primary school, 94 (42\%) participants followed a program within a heterogeneous class setting hereinafter referred to as 'Traditional Education.' Another 95 (42\%) followed a similar program, but attended pull out programs with highly able peers for at least four hours a week. The remaining $36(16 \%)$ participants exclusively attended specialized education, meant for the highly able, hereinafter referred to as 'Fulltime Gifted Education.' Of all the participants, 39 (17.2\%) spoke (partly) another language than English or Dutch at home. Table 1 shows the geographical distribution of the participants in the Netherlands. The schools where the participants were enrolled based their education on different principles, focuses, and programs. Collectively, they represented the wide spectrum of approach towards secondary education in the Netherlands.

\section{Materials}

After having received parents' concern, participants were asked to draw an intelligent person and to fill out a questionnaire. On the front page of the 
questionnaire, an area covering $75 \%$ of the page was reserved to make the drawing within a box. At the top, there were questions concerning the participants, about gender, age, program followed at primary school, and language spoken at home. Questions on the back page concerned the person they drew. The first question was about gender and age, followed by a request to rate, on a six-point rating scale, to which degree ( 1 absolutely not, 2 a little, 3 a little less than normal, 4 a little more than normal, 5 good, 6 very good) the following characteristics and talents fitted their pictured person.

Characteristics and talents presented were:

- This person has good technical skills

- This person is imaginative

- This person is mathematically talented

- This person is persisting

- This person is well liked by others

- This person is talented in languages

- This person is hardworking

- This person is talented in computer sciences

- This person is talented in artistic areas

- This person is talented in science

- This person makes friends easily

- This person is cooperative

- This person is creative

Finally, the participants had the opportunity to add important characteristics not yet asked for.

The questions 'This person has good technical skills,' 'This person is imaginative,' 'This person is mathematically talented,' 'This person is well liked by others,' 'This person is talented in languages,' 'This person is hardworking' and 'This person is talented in artistic areas', were similar to those asked in the research done by Aljughaiman et al. (2012), however five questions were added. As Boekaerts (2003) stated that Dutch youngsters had a deep personal desire to be liked by their peers, the question 'This person likes to be around people' was added. The questions about computer sciences and science were added, as in the Netherlands, women are still underrepresented in those areas; the participation of highly educated women in computer sciences decreased to $11.3 \%$ (Van Uitert \& Van der Aalst, 2014). In addition, the questions about persistence, being cooperative, and making friends easily, 
Table 2 Cross Tabulation of Gender of the Participant and Gender of the Depicted Person

\begin{tabular}{lrrrrr}
\hline $\begin{array}{l}\text { Gender of the } \\
\text { participant }\end{array}$ & \multicolumn{3}{c}{ Gender of the depicted person } & Total \\
\cline { 2 - 5 } & Male & Within gender & Female & Within gender & \\
\hline Male & 116 & $98.3 \%$ & 2 & & 118 \\
Female & 38 & & 61 & $61.6 \%$ & 99 \\
\hline
\end{tabular}

were added to get more insight into mind-set and the social status of the pictured intelligent person.

\section{Procedure}

Data were gathered in a regular classroom, as part of a lesson. Students were asked not to talk with each other, and desks were placed separately from each other. They were told not to turn the page until a signal was given. First, they were asked to answer the questions concerning themselves. Then they were asked to draw a picture of an intelligent person within five minutes. After five minutes of drawing, a signal was given. The participants all turned their page and subsequently answered the questions concerning age and gender of the person they depicted, rated characteristics, and had the opportunity to add important characteristics not yet asked for. The whole procedure took twelve minutes.

\section{Results}

Difference in gender pictured by boys and girls was found. Most of the male participants pictured their own gender. Two boys pictured a woman and added mum to their picture. Boys drew significantly more boys and girls drew significantly more girls $\left(\chi^{2}(1, n=217)=93.82, p<0.001\right)$. The detected impact of the gender of the participant on the gender of the picture was high $(\Phi=$ 0.658). Still a substantial number of the girls drew a male person as is shown in Table 2.

A difference in age, attributed to the male and the female pictures, was detected. The participants attributed a mean age of 25 years and 8 months, to the male pictures. The mean age attributed to the female pictures was 14 years and 1 month. Comparing data of participants living in a rural area, to data of participants living in big cities, a significant difference in attributed age was detected. Participants living in a rural area attributed a higher age to their depicted person $(M=27.85, S D=20.2)$ than those living in the city $(M=$ $18.64, S D=12.2), t(114.37)=-350, p=0.001$. Looking at the gender of these depicted intelligent persons, another significant difference was detected. Participants living in a rural area attributed a higher age to their depicted males 
Table 3 Mean Rating, of Characteristics and Talents, on a Scale from 1-6, in Order of Rating Score

\begin{tabular}{lrrllrr}
\hline Characteristics and talents & $M$ & $S D$ & & Characteristics and talents & $M$ & $S D$ \\
\hline Hardworking & 5.29 & 1.16 & & Talented in computer sciences & 4.54 & 1.53 \\
Mathematically talented & 5.30 & 1.01 & & Imaginative & 4.28 & 1.50 \\
Talented in Science & 4.94 & 1.25 & & Liked by others & 3.94 & 1.58 \\
Persistent & 4.82 & 1.29 & & Cooperative & 3.84 & 1.60 \\
Good technical skills & 4.65 & 1.29 & & Talented in artistic areas & 3.58 & 1.56 \\
Creative & 4.43 & 1.59 & & Makes friends easily & 3.46 & 1.62 \\
Talented in languages & 4.67 & 1.35 & & & \\
\hline
\end{tabular}

$(M=31.09, S D=21.36)$ than participants living in a city did $(M=21.34, S D=$ $14.01), t(94.61)=-299, p=0.04$. No significant difference in age between the female pictures of participants, living in a rural area and participants living in a city was detected.

In attributing characteristics and talents to an intelligent person, most participants depicted an intelligent person as hardworking, persistent, and talented in mathematics and sciences. Having technical skills, being creative, and talented in languages and computer sciences, was rated less important, but still above average. Social skills and talent in artistic areas were rated average. One boy added 'endless' to the scale and rated hardworking, mathematically talented, talented in science and creative, as endless. In Table 3, attributed characteristics and talents are displayed in order of rating.

Comparing ratings of talents and characteristics given by boys, with ratings of talents and characteristics given by girls, some significant differences were detected. Boys rated 'technical skills' and 'talented in computer sciences' higher than the girls did. On the other hand, all characteristics linked to social skills were rated higher by the girls; the girls rated 'liked by others,' 'cooperative' and 'making friends easily' higher than the boys did, as is shown in Table 4. Concerning the characteristics 'hardworking,' 'persistent,' 'imaginative,' and 'talented in mathematics,' 'science,' 'languages' or 'arts', there was no substantial difference detected between the genders.

Comparing ratings based on former primary education, a significant difference in the rating of 'technical skills' was perceived. Participants who attended a pull out program or 'Full time Gifted Education' rated 'technical skills' higher $(M=4.83, S D=1.27)$ than participants, who attended 'Traditional Education' ( $M=4.41, S D=1.29), t(218)=-2.44, p=0.015$. Comparing ratings of participants who attended a pull-out program with participants who attended 'Full time Gifted Education', there was also a significant difference in 
Table 4 Significant Differences in Rating of Talents and Characteristics between Boys and Girls Characteristics and Talents

\begin{tabular}{|c|c|c|c|c|c|c|c|}
\hline \multirow[t]{2}{*}{ Characteristics and talents } & \multicolumn{2}{|c|}{ Rating boys } & \multicolumn{2}{|c|}{ Rating girls } & \multirow[t]{2}{*}{$d f$} & \multirow[t]{2}{*}{$t$} & \multirow[t]{2}{*}{$p$} \\
\hline & $M$ & $S D$ & $M$ & $S D$ & & & \\
\hline Technical skills & 4.81 & 1.36 & 4.46 & 1.20 & 215 & 1.97 & 0.050 \\
\hline Talented in computer sciences & 4.74 & 1.51 & 4.28 & 1.55 & 213 & 2.20 & 0.029 \\
\hline Liked by others & 3.66 & 1.66 & 4.30 & 1.42 & 212 & 2.96 & 0.003 \\
\hline Cooperative & 3.59 & 1.66 & 4.16 & 1.49 & 214 & 2.65 & 0.009 \\
\hline Making friends easily & 3.20 & 1.59 & 3.79 & 1.57 & 211 & 2.70 & 0.008 \\
\hline
\end{tabular}

Table 5 Significant Differences in Ratings Based on Language Spoken at Home Characteristics and Talents

\begin{tabular}{|c|c|c|c|c|c|c|c|}
\hline \multirow[t]{2}{*}{ Characteristics and talents } & \multicolumn{2}{|c|}{ Other $(n=39)$} & \multicolumn{2}{|c|}{ Dutch $(n=186)$} & \multirow[t]{2}{*}{$d f$} & \multirow[t]{2}{*}{$t$} & \multirow[t]{2}{*}{$p$} \\
\hline & $M$ & $S D$ & $M$ & $S D$ & & & \\
\hline Hardworking & 5.62 & 0.91 & 5.22 & 1.20 & 69.62 & -2.30 & 0.024 \\
\hline Persistent & 5.26 & 1.23 & 4.72 & 1.29 & 220 & -2.38 & 0.018 \\
\hline Talented in Languages & 5.10 & 1.14 & 4.57 & 1.38 & 64.15 & -2.53 & 0.014 \\
\hline Liked by others & 4.47 & 1.54 & 3.83 & 1.57 & 216 & -2.29 & 0.023 \\
\hline Cooperative & 4.41 & 1.43 & 3.71 & 1.61 & 218 & -2.51 & 0.013 \\
\hline
\end{tabular}

the rating of 'technical skills' detected. Participants who attended 'Full Time Gifted Education' $(M=5.21, S D=1.01)$, rated technical skills higher than participants who attended a Pull-out-Program $(M=4.72, S D=1.33), t(60.04)=-2.21$, $p=0.039$.

Comparing ratings of participants living in the city with participants living in a rural area a significant difference was detected. Participants living in a city $(M=4.15, S D=1.6)$ rated 'liked by others' higher than participants living in a rural area $(M=3.62, S D=1.5), t(216)=2.44, p=0.016$.

Comparing ratings of participants who only spoke Dutch or English at home with ratings of those speaking (partly) another language at home, significant differences were detected. The characteristics 'hardworking,' 'persistent,' 'liked by others, 'cooperative,' and 'talented in languages,' were all rated higher by those, who spoke another language at home, see Table 5.

Though analysing pictures usually requires interpretation, pictured Einsteins, glasses, formulae and smiles, were identified without any problem concerning interpretation (see Table 6). Of the 91 smiles drawn, 28 were drawn by participants who attended 'Traditional Education' (36.8\%), 41 $(43.2 \%)$ were drawn by participants who attended a pull-out program and 11 (34.4\%) were drawn by participants who attended 'Full time Gifted Edu- 
Table 6 Scored Items in Pictures Made by Boys and Girls

\begin{tabular}{|c|c|c|c|c|c|c|}
\hline \multirow[t]{2}{*}{ Picture } & \multicolumn{2}{|c|}{ Boys } & \multicolumn{2}{|c|}{ Girls } & \multicolumn{2}{|c|}{ Total } \\
\hline & $n$ & $\%$ & $n$ & $\%$ & $n$ & $\%$ \\
\hline Einstein & 25 & 21.0 & 10 & 9.9 & 35 & 15.4 \\
\hline Glasses & 59 & 49.6 & 40 & 39.6 & 99 & 44.0 \\
\hline Formulae & 20 & 16.8 & 15 & 14.5 & 35 & 15.9 \\
\hline Braces & 10 & 8.3 & 5 & 4.9 & 15 & 6.6 \\
\hline Smile & 44 & 37.0 & 47 & 46.5 & 91 & 40.5 \\
\hline
\end{tabular}

cation.' Protests were added to the picture to make clear that an intelligent person cannot be recognized by his or her appearance ( $15 \mathrm{girls}=14.7 \%, 2$ boys $=1 \%$, total $17=7.5 \%$ ). 'Nerd' was added 4 times to the picture, once together with the comment: 'he is bullied.' Four participants following Full Time Gifted Education suggested adding an extra characteristic like: She is always there for you when you need her, supportive, helpful, caring. One girl drew a boy and a girl and another girl drew a person being a boy and a girl at the same time.

\section{Discussion}

Because implicit theories of intelligence play a crucial role in our learning, in this study gifted seventh graders attributions of characteristics and talents to an intelligent person were studied, in order to investigate their implicit theories of an intelligent person. Rated were the characteristics and talents 'hardworking,' 'mathematically talented,' 'talented in science,' 'persistence,' 'talented in technical skills,' 'creativity,' 'talented in languages,' 'talented in computer sciences,' 'being imaginative,' 'liked by others,' 'being cooperative,' 'talented in artistic areas,' and 'making friends easily.' Differences in gender, former primary education, geographical circumstances, and language spoken at home were taken into account. A congruence in outcomes with results gathered in Germany (Aljughaiman et al., 2012) was expected.

Boys as well as girls rated 'hardworking' and 'persistent' as a very important characteristic of an intelligent person. Further investigation could clarify whether this is a consequence of age, or of a mind shift having taken place due to being educated in theories of Caroll Dweck (2006).

Around the age of ten, influences of negative gender-role stereotypes on achievement of girls in mathematics become evident in a decreasing selfefficacy and in avoidance of the subject (Händel \& Ziegler, 2012). Apparently, concerning mathematics and science, girls do not suffer any more from negative gender role stereotypes. Depicted females were envisioned as being as 
talented as the depicted boys were. This is not in accordance with outcomes in Germany. German students who drew an intelligent person attributed more talent in mathematics to their depicted males than to their depicted females (Aljughaiman et al., 2012). However, some negative gender role stereotypes were found. 'Technical skills' and 'computer science' were rated higher, when attributed to depicted boys.

As expected, 'creative,' 'talented in languages,' and 'imaginative' seem to be considered as elements of intelligence, but not as much as 'hardworking,' 'persistent,' 'mathematics', 'sciences,' 'technical skills,' and 'computer sciences.' In Germany, an intelligent person was considered more imaginative (Aljughaiman et al., 2012). As imagery is such an important element of SelfRegulated Learning (Zimmerman, 2002) teachers should encourage the development of this characteristic in their lessons.

'Artistic talents' were not seen as an element of intelligence by all participants, which could be explained by the fact that in the Netherlands, education in arts is very poor (Schutgens, 2015; De Vreede, 2015). A limited approach, as numerous research shows the positive influence of arts on learning and the development of 21st century competences (e.g. Van Heusden, 2012).

Also 'social skills' seem not to be regarded as a part of an intelligent person. Apparently, not only girls suffer negative gender-role stereotypes. Recent research shows that in general students perceive positive social qualities of high performing classmates (Oh et al., 2015). Nevertheless, participants depicted male social skills below average. This is an example of a negative implicit theory, which impedes learning. Teachers are recommended to be attentive in recognizing these presumptions. Around the age of 12, social engagement with peers has proven to be very important (Blakemore \& Mills, 2014). Although the 'profile of the Underground learner' (Neihart, 2014) in the first place adapts to those students whose domestic setting is rooted in a culture clashing with the culture at school, the tendency to withdraw from talent development opportunities and the experience of dissonance about achieving goals is similar as they do not excel to avoid being rejected.

Differences between participants living in the city and participants living in a rural area were not as expected. Although attributing a higher age to the depicted male pictures could be the consequence of traditional values, there are no other indicators for differences due to traditional values. The influence of internet and the relatively high ranking of 'hardworking' and 'persistent' by all participants could explain this. Not foreseen was the lower rating of 'liked by others' by participants living in a rural area. This difference might 
be explained by the fact that social interaction with peers in a rural area is often not as easy as in the city. Due to greater distances between home and school (De Jong, \& Daalhuizen, 2014), coming together is not always possible. If we take into consideration the fact that highly educated Dutch more and more tend to raise their children in the city (De Jong \& Daalhuizen, 2014; Steenbekkers, Simon, \& Veldheer, 2006), we assume that for those living in the city it might be easier to connect with a peer.

The former primary education seems to influence the image of an intelligent person, considering higher ratings of 'technical skills' and the greater amount of 'smiles' attributed to an intelligent person, by those who attended a pull-out program or 'Full time Gifted Education.'

Students with a different cultural background seem to consider 'hardworking' and 'persistent' more characteristic for an intelligent person than students with a Dutch background do. Students with a different cultural background also seem to have more regard for social skills. This is in line with the research findings of Aljughaiman et al. (2012); Kenyan students regarded social emotional competence as an essential part of intelligence and rated social skills higher than the students from Germany did. Further specified research on implicit theories of intelligence of these different cultural backgrounds is recommended.

Though all indicators mentioned in DAST (Chambers, 1983) were detected, a lot of glasses were drawn. Nearly as often, a big smile was detected in the pictures. The fact that $40.5 \%$ of the participants considered an intelligent person as happy is encouraging. Although some pictures clearly were nonwestern, it was difficult to assess objectively if persons drawn were European. Only after having determined the background of the student, features that could be non-western were recognized as such. It is unknown if students who speak a different language at home suffer from Dutch presumptions, considering them less intelligent, as assumed by Trommelen (2001).

Regarding the added protests and the drawings of a male as well as a female, or a creature partly male, partly female, it seems that some Dutch girls are quite emancipated. It is interesting that Finnish participants of research done by Räty et al. (2010), who had to draw an ordinary pupil and an intelligent pupil, added similar comments to their pictures as the Dutch did.

Concern should be given to the difference in attributed age to the depicted females of Dutch students. In other cultures, an intelligent person tends to be depicted as an adult (Aljughaiman et al., 2012; Räty \& Snellman, 1997). This corresponds to the present findings regarding the depicted males in the Netherlands. The mean age of Dutch females represented in the pictures of 
this study is 14 years. Some drew themselves adding their name and 'cleverest child on earth.' Is this a consequence of what Neihart (2014) calls complacent? Or is this a consequence of missing adult role models in their life? This issue requires further investigation.

In this research, participants attending first year Gymnasium or VWO+ (enriched academic secondary education, seventh grade,) were selected in order to be able to compare our data with findings of Aljughaiman et al. (2012). Research done by Boekaerts (2003) and the PISA test concerned students attending the third year (ninth grade). A difference in mind-set could be explained as a consequence of a mind shift, however, it could also be a consequence of difference in age. It would be interesting to follow up this research in three years' time. They will have reached an age more corresponding to the research done by Boekaerts (2003) and will be legally allowed to have a job. A study with a longitudinal design will allow researchers to monitor changes in Dutch students' implicit theories and to evaluate implemented recommendations. This study provides new information regarding implicit theories of an intelligent person held by Dutch students. For the future, a longitudinal investigation of implicit theories of intelligence is planned. As teachers play such a crucial role, sending out a lot of implicit messages, it would be interesting to include their implicit theories in this research.

\section{References}

Aljughaiman, A., Duan, X., Händel, M., Hopp, M., Stoeger, H., \&, Ziegler, A. (2012). A cross-cultural study of implicit theories of an intelligent person. Turkish Journal of Giftedness and Education, 2, 2-17.

Becker, J., \& De Hart, J. (2006). Godsdienstige veranderingen in Nederland: Verschuivingen in de de binding met de kerk en de Christelijke traditie [Religious changes in the Netherlands: Shifting connections with the church and the Christian tradition]. Den Haag, The Netherlands: Sociaal en Cultureel Planbureau.

Belfiore, E., \& Bennet, O. (2010). Beyond the 'toolkit approach:' Arts impact evaluation research and the realities of cultural policy-making. Journal for Cultural Research, 14(2), 121-142.

Bilharz, T., Bruhn, R., \& Olson, J. (2000). The effect of early music training on child cognitive development. Journal of Applied Developmental Psychology, 20(4), 615-636.

Blakemore, S. J., Wolpert, D., \& Frith, C. (2000). Why can't you tickle yourself? Neuroreport, 11, 11-16.

Blakemore, S. J., \& Mills, K. J., (2014). Is adolescence a sensitive period for sociocultural processing? Annual Review of Psychology, 65, 187-207.

Boekaerts, M. (2003). Adolescence in Dutch culture: A self-regulation perspec- 
tive. In F. Pajares \& T. Urdan (Eds.), International perspectives on adolescence (pp. 108-116). Greenwich, CT: Information Age Publishing.

Bolduc, J., (2009). Effects of a music program on kindergartners' phonological awareness skills. International Journal of Music Education, 27(1), 37-47.

Burkley, M., Burkley, E., Parker, J., \& Sterner, S. P. (2009). Trait beliefs that make women vulnerable to math disengagement. Personality and Individual Differences, 48, 234-238.

Buys, L., \& Miller, E. (2009). Enhancing social capital in children via school-based community cultural development projects: A pilot study. International Journal of Education \& the Arts, 10(3), 1-19.

Chambers, D. W. (1983). Stereotypic images of the scientist: The draw-a-scientist test. Science Education, 67(2), 255-265.

Chany, J., Burke, A., \& Burkley, E. (2011). Do American Indian mascots= American Indian people? Examining implicit bias towards American Indian people and American Indian mascots. American Indian and Alaska Native Mental Health Research: The Journal of the National Center, 18(1), 42-62.

Chen, S. W., Wang, H. H., Wei, C. F., Fwu, B. J., \& Hwang, K. K. (2009). Taiwanese students' self-attributions for two types of achievement goals. Journal of Social Psychology, 149(2), 179-194.

Chiao, J. Y. (2009). Cultural neuroscience: A once and future discipline. Progress in Brain Research, 178, 287-304.

De Jong, A., \& Daalhuizen, F. (2014). De Nederlandse bevolking in beeld: Verleden Heden Toekomst [The Dutch population in the picture: Past Present Future]. Den Haag, The Netherlands: PBL.

De Vreede, M. (2015). Hoe staat het ervoor in het PO? Een peiling in het najaar. [What is the situation in primary education? A sounding in fall]. Kunstzone, 5, 52-53.

Delgado, M. R., Frank, R. H., \& Phelps, E. A. (2005). Perceptions of moral character modulate the neural systems of reward during the trust game. Nature Neuroscience, 8, 1611-1618.

Dweck, C. S. (2006). Mindset: How you can fulfil your potential. New York, NY: Random House.

Dweck, C. S., Chiu, C., \& Hong, Y. (1995). Implicit Theories and their Role in Judgement and Reactions: A Word from two Perspectives. Psychological Inquiry: An International Journal for Advancement of Psychological Theory, 6(4), 267-285.

Elfland, A. D. (2002). Art and cognition: Integrating the visual arts in the curriculum. New York, NY: Teachers College Press.

Eisner, E. (2009). What education can learn from the arts. Art Education, 62(2), 6-9.

Fletcher, P. C., \& Frith, C. D. (2009) Perceiving is believing: A Bayesian approach to explaining the positive symptoms of schizophrenia. Nature Reviews Neuroscience, 10, 1464-1484. 
Frith, U., \& Frith, C. (2010). The social brain: Allowing humans to boldly go where no other species has been. Philosophical Transactions of the Royal Biological Sciences Society, 365(1537), 165-176.

Hallam, S. (2010). The power of music: Its impact on the intellectual, social and personal development of children and young people. International Journal of Music Education, 28(3), 269-289.

Han, S., \& Northoff, G. (2008). Culture-sensitive neural substrates of human cognition: Transcultural neuroimaging approach. Nature Reviews Neurosciences, 9, 646-654.

Händel, M., \& Ziegler, A., (2012). Integrated STEM for regular and gifted students in Germany. In K. Tae-wan \& L. Gwang-Hyeong (Eds.), Promoting the gifted to be real- world problem- solver through interdisciplinary education (pp. 99112). Daejeon, Korea: Kaist.

Hetland, L. (2008). Het spoor van vier onderzoeken [The trail of four studies]. Cultuur en Educatie, 23, 54-84.

Hetland, L., \& Winner, E. (2004). Cognitive transfer from arts education. In E. Eisner, \& M. Day (Eds.), Handbook of research and policy in art education (pp. 135-162). Alexandria, VA: National Art Education Association.

Ho, Y. C., Cheung, M. C., \& Chan, A. S. (2003). Music training improves verbal but not visual memory: Cross sectional and longitudinal explorations in children. Neuropsychology, 17, 439-450.

Klepsch, M., \& Logie, L. (1982). Children draw and tell: An introduction to the projective uses of children's human figure. New York, NY: Brunner/Mazel.

Knoop, H. (2015, August). Positive psychology in education: How fairness, wellbeing and performance are mutually depending aspects of future education. Paper presented at the 21st Biennial World Conference of the WCGTC, Odense, Denmark.

Kordes, J., Bolsinova, M., Limpens, G., \& Stolwijk, R. (2013). Resultaten Pisa - 2012 [Results Pisa - 2012]. Arnhem, The Netherlands: CITO.

Krabbendam, A. C. (2012, March). Niemand stapt tweemaal in dezelfde rivier [Nobody enters the same river twice] (Inaugural oration). Vrije Universiteit, Amsterdam, The Netherlands.

Law, Y.-K. (2009). The role of attribution beliefs, motivation and strategy use in fifth-graders' reading comprehension. Educational Research, 51(1), 77-79.

Leder, H., Forster, M., \& Gerger, G. (2011). The glasses stereotype revisited: Effects of eyeglasses on perception, recognition, and impression of faces. Swiss Journal of Psychology, 70, 211-222.

$\mathrm{Li}$, J. (2002). A cultural model of learning: Chinese 'heart and mind for wanting to learn.' Journal of Cross-Cultural Psychology, 33, 248-269.

Manabu, S. (2002, July). Can post-modern science teachers change modern children's images of science. Paper presented at the 33 Annual Conference of the Australasian Science Education Research Association, Townsville, Australia. 
Marlet, G., Poort, J., \& Laverman, F. (2007). De kunst van investeren in cultuur [The art of investing in culture]. Amsterdam, The Netherlands: SEO.

Mead, M., \& Métraux, R. (1957). Image of the scientist among high-school students. Science, 126, 384-390.

Ministerie van Onderwijs, Cultuur en Wetenschap. (2014, 23 April). Passend onderwijs en hoogbegaafdheid [Suitable education and giftedness]. Retrieved from https://www.koepelhb.nl/documenten/kamerbrief_passend _onderwijs_enq_hoogbegaafdheid.pdf

Neihart, M., \& Betts, G. T. (2010). Revised profiles of the gifted and talented. Retrieved from www.talentstimuleren.nl

Neihart, M. (2014, November). Conferentie Passend onderwijs en (Hoog)begaafdheid [Conference Adapted Education and (High) Ability]. Keynote address at the conference The Revised Profiles of the Gifted and Talented: A Research Based Approach, Utrecht, Netherlands.

Nosek, B. A., Smyth, F. L., Sriram, N., Lindner, N. M., Devos, T., Ayala, A., ... \& Greenwald, A. G. (2009). National differences in gender-science stereotypes predict national sex differences in science and math achievement. Proceedings of the National Academy of Sciences, 106, 10593-10597.

Ommundsen, Y. (2001). Self-handicapping strategies in physical education classes: The influence of implicit theories of the nature of ability and achievement goal orientations. Psychology of Sport and Exercise, 2, 139-156. OECD (2011). PISA 2009 at a glance. Paris, France: OECD.

Oh, H., Sutherland, M., Stack, N., Del Mar, M., Blumen, S., Nguyen, Q. A., ... \& Ziegler, A. (2015). A cross-cultural study of possible iatrogenic effects of gifted education programs: Tenth graders' perceptions of academically high performing classmates. High Ability Studies, 26(1), 152-166.

Paul, L. (2005). Beeldvorming in Nederland [Public image in the Netherlands]. Geografie, 9, 28-31.

Picker, S. H., \& Berry, J. S. (2000). Investigating pupils' images of mathematicians. Educational Studies in Mathematics, 43(1), 65-94.

Rapp-Paglicci, L., Stewart, C., \& Rowe, W. (2011). Can a self-regulation skills and cultural arts program promote positive outcomes in mental health symptoms and academic achievement for at-risk youth? Journal of Social Service Research, 37(3), 309-319.

Räty, H., Hämäläinen, A., Kolesnikov, V., Komulainen, K., \& Skorokhodova. (2010). A picture is worth a thousand words: A comparison of pupils' images of intelligence in Finnish and Russian Karelia. Social Psychology of Education, 14(1), 1-22.

Räty, H., \& Snellman, L. (1997). Children's images of an intelligent person. Journal of Social Behavior and Personality, 12, 773-784.

Roepstroff, A., Niewohner, J., \& Beck, S. (2010). Enculturing brains through patterned practices. Neural Networks, 23, 1051-1059. 
Rubin, E., \& Cohen, A. (2003). The images of scientists and science among Hebrew- and Arabic-speaking pre-service teachers in Israel. International journal of Science Education, 25, 821-846.

Schibeci, R. (2006). Student images of scientists: What are they? Do they matter? Teaching Science, 52(2), 12-16.

Schibeci, R. A., \& Lee, L. (2003). Portrayals of science and scientists, and 'science for citizenship.' Research in Science \& Technological Education, 21, 177-192.

Schutgens, M. (2015). Kunsteducatie in het licht van de Europese ontwikkelingen [Arts education in the light of European developments]. Kunstzone, 5, 22-23.

Segers, E., \& Hoogeveen, L. (2012). Programmeringsstudie inzake excellentie onderzoek primair, voortgezet en hoger onderwijs [Programming study on excellence research primary secondary and higher education]. Nijmegen, The Netherlands: In opdracht van OCW.

Southgate, D. E., \& Roscigno, V. J. (2009). The impact of music on childhood and adolescent achievement. Social Science Quarterly, 90(1), 4-21.

Stoeger, H. (2009). The one sigma problem: The impact of beliefs in intelligence, achievement and creativity. In Shi, J. (Ed.), Cultivation of creativity and innovation (pp. 85-96). Beijing, China: CIEC.

Steenbekkers, A., Simon, C., \& Veldheer, V. (2006). Thuis op het platteland [At home in the countryside]. Den Haag, The Netherlands: Sociaal Cultureel Planbureau.

Sternberg, R. J. (2002). Cultural explorations of human intelligence around the world. Online Readings in Psychology and Culture, 4(3). Retrieved from https://doi.org/10.9707/2307-0919.1035

Sternberg, R. J. (2004). Culture and intelligence. American Psychologist, 5, 325338.

Sternberg, R. J. (2007). Who are bright children? The cultural context of being and acting intelligent. Educational Researcher, 3, 148-155.

Sternberg, R. L., Conway, B. E., Ketron, J. L., \& Bernstein, M. (1981). People's conceptions of intelligence. Journal of Personality and Social Psychology, 41, 3755.

Trommelen, J. (2001, 3 February). Niet dommer, maar minder intelligent [Not dumber but less intelligent]. De Volkskrant. Retrieved from https://www .volkskrant.nl/nieuws-achtergrond/niet-dommer-maar-minder -intelligent $\sim$ b4335foe/

Van Heusden, B. (2012). Wat leren we van cultuuronderwijs? [What do we learn from cultural education?]. Rotterdam, The Netherlands: Kenniscentrum Cultuureducatie Rotterdam.

Van Uitert, K., \& Van der Aalst, M. (2014). Sector beschrijving informatica en communicatie [Sector description computer science and communication]. Amsterdam, The Netherlands: UWV. 
Ziegler, A., Vialle, W., \& Wimmer, B. (2013). The actiotope model of giftedness: A short introduction to some central theoretical assumptions. In S. N. Phillipson, H. Stoeger \& A. Ziegler (Eds.), Exceptionality in East-Asia: Exploration in the Actiotope model of giftedness (pp. 1-17). Abingdon, England: Routledege.

Zimmerman, B. J. (2000) Self-efficacy: An essential motive to learn. Contemporary Educational Psychology, 25, 82-91.

Zimmerman, B. J. (2002). Becoming a self-regulated learner: An overview. Theory into Practice, 41, 64-67. 


\title{
Gifted Children's Drawings and Significant Others' Needs
}

\author{
Aikaterini D. Gari \\ National and Kapodistrian University of Athens, Greece \\ agari@psych.uoa.gr
}

Athina Papakonstantinou

National and Kapodistrian University of Athens, Greece ath.la.papak@gmail.com

loanna Mandaliou

National and Kapodistrian University of Athens, Greece joannamandal@windowslive.com

\section{Vassiliki Nikolopoulou}

National and Kapodistrian University of Athens, Greece vndd@hotmail.com

\section{Theodoros Kokkinos}

University of Thessaly, Greece

theokokkinos@yahoo.gr

The first purpose of this study is to expand previous research on children's drawings to the specific case of children with high learning abilities. A second aim is to look into the features and needs of the gifted students families in Greece. A main result is that gifted children's parents are primarily worried about finding age-appropriate activities to address their children's desire for knowledge and emotional needs. Family and class drawings can be utilized as an additional source of information available for teachers and psychologists to assess emotional needs of the gifted children and their families, taking into account all the relevant limitations.

Keywords: high abilities children, gifted children, parents' worries, family drawings, class drawings, drawings coding systems, qualitative analysis

\section{Introduction}

The definition of giftedness is often an issue located in the centre of a heated debate. Many different interpretations and models have been proposed, the majority of which suggests that cognitive abilities - either as general intellectual ability or as specific skills or talents - are necessary but not always sufficient condition for intellectual high-ability indication (Subotnik, OlszewskiKubilius, \& Worrell, 2012). According to the later form of the Renzulli's model, giftedness is constituted by the high mental abilities, high creativity and 
motivation to achieve goals under the influence of sociocultural factors as they emerge through the critical influence of family, school and peers (Gari, Kalanzi-Azizi, \& Mylonas, 2000; Gari \& Tsigri, 2009; Mönks, Van Boxtel, Roelefs, \& Sanders, 1986; Renzulli, Reis \& Smith, 1981). However, multidimensional models for giftedness show that excellent achievement in various fields is based on some physical abilities and a combination of several interpersonal characteristics such as motivation, prior knowledge and specific skills (Heller, 1992; Heller, Perleth, \& Lim, 2005; Vogl, \& Preckel, 2014). Their identification by parents is usually the first step towards the establishment of giftedness. Parental approval and mainly parental attitudes and behaviours seem to be crucial for the child and the realization of its own potential and afterwards for the development of gifted characteristics.

In the past, research for gifted children's families was predominately made to address two main needs: To determine how family life creates talents and to investigate how the identification of giftedness affects siblings (Silverman \& Kearney, 1989). Later, other researchers on an attempt to shed light on the particularities of these families, offered a large number of studies aiming to point out the main concerns of parents of talented children and highlighting some key areas as sources of concern: Roles in the family and adaptability, relationships with siblings, parents' self-concept, issues relating to neighbourhood and community, educational issues, and child development (Keirouz, 1990; Windecker-Nelson, Melson \& Moon, 1997). Moreover, identification of the gifted students seem to affect particular regions of sibling relationship, as competition seems to affect positively identified siblings, but negatively an unidentified sibling (Grenier, 1985). In addition, the relationship between the non-gifted children and their gifted brothers is less closed, as mentioned by the children themselves, compared to those between non-gifted siblings. They dislike the arrogance of their gifted brothers and wish they had similar cognitive skills. Brothers in 'normal' families express the same antipathy to a much lesser extent (Lapidot-Berman \& Oshrat, 2009).

Another set of studies was designed to investigate giftedness as it is perceived and expressed within the family. Freeman (1995) stressed that parents may face emotional difficulties or feeling inadequate, or even trying to get social benefit from their child's exceptional skills. She concluded that sometimes parents may be greedy, raising excessive expectations for their child. When in fact parents realize that a child or one of their children may has exceptional capabilities, a fear of failure and frustration ultimately brings often harmful repercussions on the child's emotional adjustment. To put it in another way parents may fall into the trap of the stereotypes related to high 
abilities that prevail within the specific society they live (Post, 1994). In general, several authors over the last two decades were trying to highlight the importance of the quality of mother - child relationship and the relationships among family members in the learning procedure and intellectual development (Boekaerts, 1991; Freeman, 1995). Their conclusions advocate that parental competence is a key component of young gifted children's social competence (Windecker-Nelson et al., 1997). Similarly, Olszewski-Kubilius, Lee, and Thomson (2014) found high correlation between support and affection of family relationships and gifted children's development of interpersonal skills and friendships.

Empirical research studies also suggest also teachers who seem to be effective to identify and teach the gifted students have the following characteristics: enthusiasm (Chandler \& Bean, 1998; Heath, 1997; Sisk, 1989; Whitlock \& DuCette, 1989), flexibility (Renzulli, Reis, \& Smith, 1981), creativity (Chandler \& Bean), and expertise in the area (Sisk, 1989). Documentation of the 'credentials' of teachers is widely accepted as a means of evaluating their general effectiveness, of increasing their potential to identify the gifted and talented students and an index of the quality of an educational system. On the other hand, it is also widely argued that teachers need formal training with a strong emphasis on methodology courses and strategies to understand student's potential and special needs, in order to be considered competent, capable teachers (Heath, 1997; Shore, Cornell, Robinson, \&Ward, 1991) and also to support all students' different learning and psychosocial characteristics (Mills, 2003; Mills \& Parker, 1998).

\section{Drawings as a Technique to 'Assess' the Gifted Students' Needs}

Projective methods such as drawings can be used when other techniques are excluded because of language or communication restrictions or different cultural backgrounds (Singh \& Rossouw, 2015) and also when a combination of methods and strategies to explore special characteristics and needs becomes necessary. There are many on-going discussions on the need of statistical support for projective techniques, which have lasted several years. Some authors, prioritize the necessity of proving the existence of certain properties which inhere in the projective measures before these are regularly applied, while others, claim that the aforementioned techniques have already proved their usefulness when related to other valid methods (Frick, Barry, \& Kamphaus, 2010; Lilienfeld, Wood, \& Garb, 2000).

An attempt to quantify family drawings was made by Wright and Mclntyre (1982), when they created the Family Drawing Depression Scale (FDDS) 
to detect depression through the drawings. Before that, Burns and Kauffman (1970) were interested in the qualitative analysis of children's family kinetic drawings and created a coding system which includes five main diagnostic categories: Actions by and between persons in the project, Characteristics of each person's faces, Location, Distance and Barriers between persons, Style and Symbols. Kaplan and Main (1986) also developed a system for categorizing family drawings into the four types of attachment (secure, avoidant, ambivalent, disruptive), reflecting the child's representations of the type of bond with the mother based on the Bowlby's attachment theory. This coding system describes specific design characteristics associated with each of the bond types. Another rating scale, the Family Drawing Global Rating Scale - FDGRS, was made by Fury, Carlson, and Sroufe (1997). Their work was based on the Kaplan and Main classification system. The FDGRS is a 7-point grading scale of the emotional tone, quality of family relationships and attachment type to be depicted in the family drawings. FDGRS includes two positive dimensions Vitality/Creativity and Pride for the Family/Happiness, and six negative dimensions, Vulnerability, Emotional Distance/Isolation, Tension/Anger, Role-Reversal, Bizarreness/Disorganization and General Pathology (Table 1).

Great interest among researchers appeared for the kinetic approach also to school drawing because it seemed to provide a richer source of data than did static drawings (Andrews \& Janzen, 1988; Armstrong, 2004; Prout \& Celmer, 1984). School and class drawings have been used to document gifted students' perceptions of school life as they provide nonverbal documentation of gifted students' perceptions of their current school experiences. They also clearly indicate the changes the students would prefer in their schooling. Information on the particular educational preferences of gifted students can be applied, whether or not these students are served by special programs, to ensure that their school experiences meet their unique educational needs. Moreover, the students, who had been identified as gifted, demonstrated in their pictures that they preferred to learn in differentiated settings through a variety of instructional and sensory modalities. They also confirmed that they were similar to their peers by demonstrating stereotypical age and gender preferences in their pictures (Armstrong, 1995). The Kinetic School Drawing (KSD) model employs the following measures from children class drawings: 'In or out of school,' 'Engaged in an undesirable behaviour,', 'Engaged in an academic behaviour,, 'Teacher height,, 'Child height,' 'Number of peers,' 'Distance between self and teacher,' and 'Distance between self and others (Prout \& Celmer, 1984; Prout \& Phillips, 1974). 
Table 1 The List of Dimensions and Their Description of the Family Drawing Global Rating Scale FDGRS

\begin{tabular}{|c|c|}
\hline Scale & Description \\
\hline Vitality/Creativity & $\begin{array}{l}\text { Emotional investment - embellishment, use of details and creativity. It } \\
\text { reflects the existence (or non) of emotional closeness between family } \\
\text { members }\end{array}$ \\
\hline $\begin{array}{l}\text { Family } \\
\text { Pride/Happiness }\end{array}$ & $\begin{array}{l}\text { Sense that the child feels a member of the family group that is sup- } \\
\text { ported by its members, that he/she feels happy in it. This dimension } \\
\text { seeks to capture the overall sense of belonging and pride in the family } \\
\text { that the child feels. }\end{array}$ \\
\hline Vulnerability & $\begin{array}{l}\text { Sense of vulnerability, uncertainty and emotional ambivalence between } \\
\text { mother and child. It is reflected in the size of the figures, the position of } \\
\text { the figures in the drawing and the excess parts of the body/facial prox- } \\
\text { imity likeness, chaotic or confusing background. }\end{array}$ \\
\hline $\begin{array}{l}\text { Emotional dis- } \\
\text { tance/Isolation }\end{array}$ & $\begin{array}{l}\text { Emotional distance and feelings of loneliness that is reflected through } \\
\text { covert expressions of anger, negative or neutral interaction, distance } \\
\text { between child and mother. Figures of the child himself/herself or } \\
\text { mother's figure may be missing. }\end{array}$ \\
\hline Intensity/Anger & $\begin{array}{l}\text { Anger and tension implied by crowded or overlapping figures look- } \\
\text { ing like scribbles, poor in colours and details. Errors in start-ups and } \\
\text { smudges. }\end{array}$ \\
\hline Role reversal & $\begin{array}{l}\text { Suggestions of role reversal, inferred from relation of size or roles of } \\
\text { drawing figures. }\end{array}$ \\
\hline $\begin{array}{l}\text { Bizarreness/ } \\
\text { Disorganization }\end{array}$ & $\begin{array}{l}\text { Underlying disorganization expressed by unusual signs, symbols, fan- } \\
\text { tasy, themes. }\end{array}$ \\
\hline $\begin{array}{l}\text { General } \\
\text { pathology }\end{array}$ & $\begin{array}{l}\text { Overall degree of negativity reflected in global organization, complete- } \\
\text { ness of figures, and use of colour, details, affect and background to the } \\
\text { scene. }\end{array}$ \\
\hline
\end{tabular}

Notes As referred by Fury et al. (1997).

\section{Purpose of this Study}

Despite that international literature offers a significant number of studies examining the dynamics of gifted children families, there are no such results about the Greek gifted and talented children; therefore, the purpose of this study that is conducted in the Athens University's Laboratory for Creativity Development is an effort to fill this gap. The study consists of two parts: The first part seeks to outline characteristics of families of children nominated as gifted - either by their teachers or by their own parents or in cases that they were identified by specific psychodiagnostic services set out of school system. The second and main part includes four case studies of children with an emphasis on the analysis of their 'Family' and 'Class' Drawings. The extent to which the high ability children's drawings could be a useful 'tool' in the hands 
of a school psychologist is a question to be answered, along with the question whether family and class drawings can reveal children's inner feelings about the significant others within family and class systems.

\section{Method}

\section{Participants}

The sample consisted of 42 children (30 boys, 12 girls), aged of 2-16 years, whose parents approached the University of Athens Laboratory for Creativity Development in order to ask for information about a range of issues concerning the outstanding performance of their child. The decision to consult a specialist, usually emerged after references mostly by teachers (primarily from kindergartens and early primary classes) and by people in the child's environment (paediatricians, child psychiatrists, etc.). 16 children out of 42 went through a family session, during which they were asked to draw their family and their classroom. Four of these sets of drawings are being analysed at the second part of this study, in terms of a case study.

Children's mean age was 7.7 years. 16 children (55\%) had one sibling, 6 children (20\%) had no other sibling, 5 children (17\%) had two, and only 2 children $(7 \%)$ had three siblings. 18 out of 42 children (78\%) were firstborn, 3 children $(13 \%)$ were second in birth order and $2(9 \%)$ were third. Unfortunately, for the rest 13 participants no information about siblings was available.

\section{Collecting Data Strategies}

Archived Data. Data were derived from the archived material of the Laboratory of Creativity Development (2013-2016). The material includes:

- Manuscript notes from telephone calls and meetings with parents and child.

- Printed e-mail contacts.

- A semi-structured questionnaire for parents. This questionnaire includes information such as demographic data, the child's extracurricular activities, the person who made the reference, child's main characteristics, special abilities, skills, talents and developmental milestones, particular difficulties within family, school and peer groups, along with teachers' comments about their child during the current and also previous school years.

Drawings Rating Scales. Family drawings were scored using Family Drawing Global Rating Scale Family - FDGRS (Fury et al. 1997). This scoring sys- 
tem was selected as it is one of the most recent tools for family drawing analysis enabling the viewer to focus on the emotional tone of the painting, while detailed information is offered about the validity of the scale. Inter-rater Pearson $r$ values are reported as follows: Vitality/Creativity: $r=$ 0.90, Family Pride/Happiness: $r=0.76$, Vulnerability: $r=0.87$, Emotional Distance/Isolation: $r=0.57$, Stress/Anger: $r=0.77$, Role Reversal: $r=0.73$, Curiosity/Disorganization: $r=0.68$, General Pathology: $r=0.79$. Finally, it gives the benefit for the judges 'to evaluate the drawing using an overall judgment dimension rather than searching specific design symbols' (Fury et al., 1997, p. 1163).

In order to score the Family and the Class Drawings, we adapted seven out of eight dimensions of the original scale, 'adapted' to the needs of our study. For instance, instead of 'distance/absence of the mother figure' we assessed the 'distance/absence of the teacher.' Eventually, we employed seven emotional dimensions for each dyads - of Family and Class drawings.

\section{Results}

The first part of this paper analyses the qualitative data analysis using the content thematic analysis. Specifically the variables assessed are: 'Parents' requests,' 'Behaviour difficulties,' 'Teachers' reports/comments' as reported by parents, and 'Children's abilities as reported by parents.' The categories revealed for each variable derived from three judges. Three postgraduate students of the Athens University School Psychology Program conferred and agreed before the deduction of the thematic categories. All the qualitative variables were treated as a multiple responses question.

The second part analyses the Family and Class Drawings of four children. All the drawings were graded by the same three judges with a 7-point scale, from 1 'low degree of the dimension' to 7 'high degree of the dimension,' based on the FDGRS (Fury et al., 1997). The mean scores of the three judges were used for each rating.

\section{Frequency Distributions}

Table 1 presents frequency distribution of parents' requests to the Laboratory for Creativity Development. The most frequent request was about getting advice on appropriate utilization and further development of their child's skills: 'How can we help him/her develop his/her skills through activities that are appropriate to his/her age?' was a very common question. The next more frequent request was about the identification of giftedness of their child.

Furthermore, parents also reported several types of difficulties that their 
Table 2 Parents' Requests Frequencies

\begin{tabular}{lrr}
\hline Parental requests & $f$ & $r f$ \\
\hline Further skills development & 21 & 29.2 \\
Stress/behaviour management & 8 & 11.1 \\
Siblings relations & 4 & 5.6 \\
Information about enriched programmes & 11 & 15.3 \\
Information about legislation for gifted/talented students & 10 & 13.9 \\
Peer relations & 4 & 5.6 \\
Giftedness assessment & 14 & 19.4 \\
\hline Total answers & 72 & 100.0 \\
\hline
\end{tabular}

Notes $n=40$.

Table 3 Frequencies of Gifted Children's Referred Difficulties

\begin{tabular}{lrr}
\hline Children's difficulties & $f$ & $r f$ \\
\hline Anxiety/compulsion & 4 & 11.4 \\
Difficulties in accepting boundaries & 7 & 20.0 \\
Jealously/rivalry & 7 & 20.0 \\
Attention deficit/hyperactive behaviours & 3 & 8.6 \\
Difficulties in relation with peers (solitude, shyness) & 14 & 40.0 \\
\hline Total answers & 35 & 100 \\
\hline
\end{tabular}

Notes $n=20$.

Table 4 Frequencies for Teachers' Comments about Gifted Students as Referred by Parents

\begin{tabular}{lrr}
\hline Teacher's reports/comments as reported by parents & $f$ & $r f$ \\
\hline Disinterested in the educational material & 4 & 8.5 \\
Efforts of teaching differentiation & 5 & 10.6 \\
Facing difficulties in their relations with classmates & 7 & 14.9 \\
Difficulties in following rules/boundaries & 5 & 10.6 \\
Highly motivated - leader characteristics & 6 & 12.8 \\
High learning ability/special talents & 20 & 42.6 \\
\hline Total answers & 47 & 100 \\
\hline
\end{tabular}

Notes $n=22$.

child encounters (Table 2). Parents mentioned at a higher rated the difficulties their child had to confront with relations with peer groups.

Parents also answered questions about teachers' comments throughout children's school life (Table 3). It is important to underline that for those cases that teacher's comments were available (Table 4), it was clear that almost all teachers had already identified the student's exceptional skills and had reported about to parents. 
Table 5 Students' Skills and Abilities as Reported by Parents

\begin{tabular}{lrr}
\hline Fields of exceptional abilities as referred by parents & $f$ & $r f$ \\
\hline Great range of knowledge/studiousness & 18 & 13.0 \\
Creativity/imagination & 7 & 5.1 \\
Organizational skills & 6 & 4.3 \\
Chess attainments & 4 & 2.9 \\
Memory skills & 15 & 10.9 \\
Justice sense & 11 & 8.0 \\
Arts & 18 & 13.0 \\
Psychical Science skills & 11 & 8.0 \\
Mathematical meanings/numeric handling & 16 & 11.6 \\
IT skills/electric devices interest & 5 & 3.6 \\
Verbal abilities & 27 & 19.6 \\
\hline Total answers & 138 & 100.0 \\
\hline
\end{tabular}

Notes $n=36$.

Table 5 presents the fields in which the students demonstrated special skills as referred by parents. In particular, the majority of children $(75 \%$ of cases) had excellent language skills, 50\% of children are distinguished for their range of knowledge/curiosity and 50\% appeared talents in Arts (18 out of 36 ).

\section{Looking into the Drawings: Case Studies}

Christine's Case. Christine was a girl almost 7 years old, attending first grade at school when her parents contacted the University Laboratory. Her mother asked for information about enriched educational material so that Christine won't get bored at school and at home. She also wanted to find ways to help her older daughter, to understand and conciliate with her younger sister's exceptional skills. Her parents, described Christine as an amiable, competitive, imaginative, energetic child, independent and able to carry out any work. However, they also mentioned particular difficulties that were troubling her over her relationships with classmates. Particularly she often gets hurt by her peers' teases, something that she thinks it is difficult to cope with. Finally, they mentioned that lately she had fears and concerns about issues related to death and reincarnation.

The nursery teacher had distinguished that Christine is a gifted child. Her primary school teacher characterizes her as a leader, calm but strong, cooperative, organizational and mature. In class Christine gets bored, and concerning her classmates, quite often she declares frustrated from their immaturity. 
Table 6 Judges' Scores for Christine's Case

\begin{tabular}{lrr}
\hline FDGRS grades & Family drawing & Class drawing \\
\hline Vitality/Creativity & 3.7 & 4.0 \\
Sense of pride/Happiness & 5.3 & 5.3 \\
Susceptibility & 3.0 & 4.0 \\
Emotional distance/Isolation & 4.0 & 6.3 \\
Volume/Anger & 1.0 & 2.6 \\
Role Reversal & 1.0 & 1.0 \\
Bizarreness/Disorganization & 1.0 & 1.6 \\
\hline
\end{tabular}

She likes playing with a girlfriend and her cousin. Regarding the rest of the children she said that 'the children in my class tease me that I'm dumb, because they want themselves to be smarter. I try not to pay attention, but they insist. But I do not play with them.'

During the interview, Christine seemed very hesitant and tight-lipped. After a while she seemed to gain comfort with the process, readily agreed to be apart from her parents and to be left alone with the psychologist. She used to answer to the psychologist's questions panting and gasping.

Christine's family drawing is filled with vivid and bright colours. She lined up her family members next to each other sited in a green field, which filled almost one third of the sheet. The rest of her painting is filled with blue sky and a bright sun is painted in the upper left corner of the sheet. The figures are close to one another, with open hands, the face characteristics are depicted with bold lines. The design gives the impression of a happy and united family and leaves a feeling of joy and optimism.

In general, these scores in the seven dimensions indicated the prevalence of the positive dimensions. However there is a relevant high score (4) in the dimension 'emotional distance/isolation,' mainly because of the distance between the figures of the mother and herself. This dimension aims to assess feelings of loneliness or isolation on behalf of the child. Yet, according to Fury et al. (1997), the grade 'four' does not reveal clear signs that signify great emotional distance nor closeness mainly between child and mother.

Similarly, in her class drawing she used lots and vivid colours. However it is obvious that she chose to portray only her teacher and no one else something that could lead to the assumption that her drawing reflects her positive feelings for her teachers and her difficulties with her classmates.

Mary's Case. Mary's mother visited the Laboratory of Creativity Development, when her daughter was 6,5 years, requesting information as to whether she 
can be identified as gifted. Mary was described as a curious girl, behaving like a grown-up, stubborn, having slight peer contacts, yet enjoying company with older people. She was attending lots of extracurricular activities such as chess, folk dances, painting, two foreign languages, and advanced mathematics at a higher level than that of the first class grade. She was also pursuing adults' manifest approval during social events such as anniversaries, school celebrations etc. Mother also worried about Mary's perfectionism at school. Lately, she was experiencing some fears (of darkness, intense noise, falling asleep alone in bed without the presence of her mother).

During the session, she often tried to impose her own terms on the process. Mary painted her family hastily after the request of the psychologist, with simplified figures, bold and unrealistic colours e.g., blue, yellow, orange, grey hair. All family members are included in a house framework whose roof resembles that of an orthodox church. Starting from the left side to the right, there is the father the younger sister, Mary, the mother, the paternal grandmother and a grandmother's (Grandma B) family friend. The presence of her grandmother and her grandmother's friend reveals the existence of an intense link with the extended family and the importance of the older generation in family life; such an element may reveal a possible 'disruptive' effect of enmeshed relationships in which the family is exposed (Reynolds, 1978). Some noteworthy features of the drawing is the fact that all the figures are holding each other with hands that looks like continuous lines and also the size of Grandma B which is greater than all other figures. The size is mostly associated with the child's personal perception of the importance attributed to the various family members. The larger the size the more significant effect or psychological importance (Klepsch \& Logie, 1982; Reynolds, 1978).

Using the FDGRS, Mary's family drawing, scored low on the dimension Vitality/Creativity as it was considered to have poor emotional investment. The figures look like scribbles (stick figures), designed in an automatic, repetitive way. Dimension Sense of Pride/Happiness scored higher because of the emotional closeness that prevails among members. Also despite the lack of details in the background, the drawing depicts a united and happy family. Mary's drawing scored high on the five negative dimensions. Specifically, the size of the figures, the immature design (stick figures), the enlarged hands and soft body parts (hair), are some of the elements signifying emotions of vulnerability and ambivalence (Fury et al., 1997). Similarly, previous authors refer that simplified designs - stick figures - indicate possible defence mechanisms released against testing procedures, especially when the drawing is 
Table 7 Judges' Scores for Mary's Case

\begin{tabular}{lrr}
\hline FDGRS grades & Family drawing & Class drawing \\
\hline Vitality/Creativity & 1.7 & 1.3 \\
Sense of pride/Happiness & 4.7 & 4.6 \\
Susceptibility & 5.0 & 5.6 \\
Emotional distance/Isolation & 1.3 & 5.3 \\
Volume/Anger & 4.7 & 6.3 \\
Role Reversal & 5.7 & 3.0 \\
Bizarreness/Disorganization & 5.0 & 2.6 \\
\hline
\end{tabular}

'required' (Burns \& Kaufman, 1972; Reynolds, 1978). Moreover, 'false starts' indicate tension and anger (Fury et al. 1997; Leon, Wallace, \& Rudy, 2007; Pianta, Longmaid, \& Ferguson, 1999). The fact that the grandmother figure protrudes among family members, led to the high rating of the dimension Role reversal. Finally hidden feelings of anger or hostility, resulted, high levels in the dimension Bizarreness/Disorganization.

As regards Mary's class drawing it should be noted that while she was drawing her class she showed particular insistence on details of numericalmetric characteristics and when she found that she could not manage to be absolutely accurate, she adopted a logical interpretation for her mistakes. In general, one hypothesis is that her drawing reflects once again her high perfectionism which is addressed to the school framework.

George's Case. George visited the University Laboratory with his family at the age of 6 years. His parents asked for advice on how to satisfy their son's curiosity without overloading his extracurricular program. Both parents and also the teacher of the grade A indicate that, while George enjoys being among his classmates, he is not generally very easy to approach group activities. Avoidance of the peers is not rare. Teacher is trying to adapt and enrich educational activities and, at the same time, he is working with the educational counsellor to provide him further support. Parents described him as a child with unlimited interest in the natural world, technology, having impressive numeric abilities since the age of 3.5 years, constantly asking about matters concerning death, human evolution and illnesses.

His teacher's opinion is that while George is lonely, he also can work well with other children and play with them when it is necessary. His classmates have a positive opinion about him and seek his company. What they recognize as a difficulty is that he is often bored in both the classroom and his home to finish his homework. He also underlined that George has difficul- 
Table 8 Judges' Scores for George's Case

\begin{tabular}{lrr}
\hline FDGRS grades & Family drawing & Class drawing \\
\hline Vitality/Creativity & 2.3 & 2.6 \\
Sense of pride/Happiness & 1.6 & 2.3 \\
Susceptibility & 6.6 & 4.6 \\
Emotional distance/Isolation & 6.0 & 6.0 \\
Volume/Anger & 6.6 & 4.0 \\
Role Reversal & 6.3 & 2.3 \\
Bizarreness/Disorganization & 5.6 & 5.0 \\
\hline
\end{tabular}

ties approaching other children of his age although he finally enjoys being among them.

George drew his family members on the left half of the sheet in which he had already drawn his intergenerational tree before the interview. The figures appeared to be compartmentalized into sub-frames, while his-self figure frame distinguishes with an embellished double line entitle 'Me.' As noted in the previous case, the fact that he wanted to include his genealogical tree may suggest the importance of the bonds with the extended family (Reynolds, 1978), and it may also reveal a 'disruptive' effect to which the family is exposed. Regarding the designing style, compartmentalization of oneself to a separate frame and especially the separation from the father, suggests strong insecurity (Burns \& Kaufman, 1970), lack of communication with other members and the need to isolate or remove threatening individuals (Reynolds, 1978).

The low rating in the dimension Sense of Pride/Happiness is the result of disproportionation of the family size regarding the sheet size, occupying less than half the sheet and also due to the lack of details and embellishment, especially on side of the family. The figures are floating on the air, isolated in different frames. The self-figure is ugly with sharp edges (hands and legs) and designed in a harsh way. In general, his drawing doesn't imply that interaction between family members is welcomed. Role Reversal is also high because of the relative sizes of the self-figure compared with that of the father's. His drawing had also lots of smudges and false starts which resulted in high rates of the rest of the negative dimensions (Fury et al. 1997; Leon et al., 2007; Pianta et al., 1999).

In a similar way, his class drawing was deemed as one that reflects negative feelings. The lines are chaotic and they could possibly indicate existing feelings of anxiety, pressure, and the need for isolation. The absence of any person is remarkable, which may be related to the difficulty he faces to ap- 
Table 9 Judges' Scores for the John's Case

\begin{tabular}{lrr}
\hline FDGRS grades & Family drawing & Class drawing \\
\hline Vitality/Creativity & 7.0 & 6.6 \\
Sense of pride/Happiness & 5.3 & 6.0 \\
Susceptibility & 4.0 & 4.0 \\
Emotional distance/Isolation & 2.7 & 4.0 \\
Volume/Anger & 2.7 & 4.3 \\
Role Reversal & 6.3 & 2.3 \\
Bizarreness/Disorganization & 1.3 & 1.0 \\
\hline
\end{tabular}

proach his peers. There are no clear signs that a school class is depicted, even as a room in space or at least as a group of people-pupils and teacher.

John's Case. John's parents visited the University Laboratory when John was 7 years old and he was going to start B grade. Parents were asking for help about managing their son's specific emotional and behavioural problems, something that troubles his teacher as well. His mother described him as a child who is constantly curious about everything, watching documentaries; he likes doing mathematical calculations in his mind even with negative numbers and generally he is a child ready to absorb information. He has a strong, leader personality and high sense of justice. The main problem was that he has intense outbursts of anger, jealousness and commanding attitude towards his siblings. These problems began mostly after his sister birth.

In his family plan, he had drawn himself between two parents holding hands while, his siblings a little away from the centre of the family, probably implying a hidden desire to distance himself from the subgroup of siblings (Klepsch \& Logie, 1982). Central figure in the drawing is the mother, which is clearly taller than everybody else. His own-self figure was designed in details and quite groomed; According to Burns and Kaufman (1970) it may indicates that the person is influenced by the imagination or the fulfilment of a desire.

The high scores of the judges on the two positive dimensions reflect the vitality that characterizes his painting. The figures seeming cheerful, well designed and with lots of details. Interaction between family members seems to be welcomed, the bodies and heads are full (round), slightly looking as moving. In general, it seems to be a united happy family which contributed to the high rates of the dimensions Sense of Pride/Happiness. At the same time, John's drawing rated high at the negative dimension Role Reversal because of the disproportion in size between himself and his father as they are almost equal and generally because of the big size of the self-figure. 
Looking at his class drawing it seems that John does not face difficulties in his relationships with his peers, but he looks like enjoying the game with them during breaks. However, the fact that he chose to paint himself, his classmates and his teacher during a break and not within the classroom, perhaps reveals his difficulty in participating in a teamwork, since he often finds it difficult to follow instructions and respect the limits and rules of a team. It may also be related to the fact that in the classroom he is placed in one of the last desks and sits alone. As a whole, the painting produces positive emotions, the children are in a break and everyone has a wide smile. A very positive impression is created by the smiling sun at the top left angle, which seems to give rays of warmth to the whole painting.

\section{Discussion}

Content analysis of parents' requests, showed that parents of the gifted children of this sample primarily are worried about finding age-appropriate activities in order to address their child's eager to learn. Quite fewer are concerned about peer relationships issues and even fewer concerns are expressed about relationships with siblings. In other words, while in many cases parents refer current problems with peer relationships, this does not seem to be the dominant issue troubling them for the future. This contradiction seems to make sense as many authors have stressed assumptions that, except for the case of adolescents gifted in the field of Arts, the other gifted children do not show higher levels of depression, than that of the general population (Neihart \& Olenchak, 2002). They seem to be endowed with factors that enhance resilience and thus help them eventually to overcome difficulties that go along with the rapid development of cognitive skills (Neihart, 2002; Reis \& Renzulli, 2004;).

Another finding is that the vast majority of teachers sample have highlighted students' exceptional skills in our sample, although it is not easy for teachers who have not previously trained on gifted/talented students to nominate children's high abilities talents (Gari, Kalanzi-Azizi, \& Mylonas, 2000; Kaufman \& Harrison, 1986), even in the domains of verbal intelligence and Arts, in which the children of the sample demonstrate high performance. Therefore, one possible challenge for the future educators and teachers in state schools is to get trained in the near future in nominating and identifying the gifted/talented students and in embracing enriched activities and differentiating strategies designated for gifted/talented students.

Regarding the case studies presented in the second part of this paper, it seems that drawings are a useful tool in the hands of school psycholo- 
gists, and also in collaboration with class teachers. Concerning the Family Drawings based on the Family Drawing Global Rating Scale guidelines, it is clear that three out of four of the cases scored high in the negative dimension 'susceptibility,' a dimension that seeks to assess feelings of anxiety, uncertainty and emotional ambivalence. Indeed, parents of those cases Mary's, George's, and John's - reported particular difficulties experienced by the child in their relationships either with peers, or siblings, or with adults, and also in some particular fears, and in extreme needs for perfection. Another negative dimension that also prevailed was that of 'role reversal' based on the relative sizes of self and parents' figures. High scores in this dimension are implying the child's feelings of parental difficulties in accepting their giftedness and their parents' powerlessness (Fury et al., 1997).

Concerning the Class Drawings, the child's choice not to portray himself, his peers or the teacher or the general absence of any person from their classroom plan indicates clearly the child's negative feelings associated with classroom, learning process and difficulties in interacting with peers. Feelings of perfectionism and compulsion, in terms of performance in the school context, as expressed through persistence numerical-metric details, are clearly apparent in Mary's case, while insecurity and social anxiety that the child experiences in school were reflected through chaotic and intense lines, as in George's plan. However, positive emotions, a sense of joy and warmth for school were also expressed, like in John's drawing, through the depiction of the child's himself, along with classmates and the class teacher as smiling faces.

Finally, a sloppy way of design (stick figures) and harsh lines which justify the high rankings in the negative dimensions are clearly presented, especially in Mary's and George's cases. As some authors claim, the immature or careless design may reflects children's trends of isolation, indifference in interpersonal relationships (Burns \& Kaufman, 1970; Spigelman, Lungs, Sweden Spigelman, \& Englesson, 1992). However, as noted before, poor investment and lack of details may indicate negativity or boredom towards the examination procedure (Burns \& Kaufman, 1970; Reynolds, 1978).

Projective measurements have been acclaimed as a useful set of tools that can provide hints about the children's emotional state (Goldner, Edelstein, \& Habshush, 2015). Particularly, a series of studies on children's drawings declares the validity of FDGRS, for detecting elements of distress and avoidance (Fury et al., 1997; Goldner et al., 2015; Madigan, Ladd, \& Goldberg, 2003; Pace, Zavattini, \& Tambelli, 2015) and assessing psychosocial adjustment in school (Goldrner \& Scharf, 2011; Pianta et al., 1999). Yet, according to the same au- 
thors, another important thing to bear in mind, are the dangers of overestimating diagnostic capacities of children's drawings. They 'manage' to stress the importance of having additional 'diagnostic means', in order to formulate and re-evaluate a hypothesis about a child's emotional needs. In conclusion, we suggest that particularly in the case of gifted children, drawings can be utilized as an additional source of information for psycho-social assessment as they could assist psychologists and teachers to detect emotional problems, motivational barriers and generally factors that may be crucial for the gifted/talented students' effective development.

\section{Conclusions}

The gifted children parents of the sample seem to be more confused and anxious about how to address their gifted child's advanced learning needs, rather than worried about their peer and relationships problems. At 'the end of each day,' parents may trust their child's ability to adapt successfully to school and peer environment, but they do not trust themselves in which extent they are able to address their child learning and emotional needs. As regards the teachers who had already effectively highlighted students' exceptional skills, they had mentioned more often some particular emotional and behavioural difficulties of the gifted students' social life. Let bear in mind that the gifted children of the sample demonstrate high performance predominately in verbal intelligence, in Arts and in general knowledge high and fast acquisition. Therefore, education policies of the near future for all students, and much more for the high ability/gifted/talented students, have to be designated to focus on the enrichment of the existing curriculum with activities, materials and teaching strategies that embrace children's great variety of abilities, interests and socioemotional needs, instead of limiting their prospective and creativity into an 'old fashion way' of learning based on the 'average student's ability'.

High ability children's drawings can be proved to be a helpful tool of nonverbal expression of experiences and feelings in different settings. Class drawing, along with family drawing, could be particularly helpful for hypothesizing some emotional difficulties, such as social anxiety, need for isolation, negative feelings for the teacher, or the preference for free time and games rather than the classroom time. Family drawings can be also more useful in the detection of anxiety, anger and need for isolation, but also they may provide important information about the family relationships dynamics, within two or three generations of family members, that may influence the child's adaptation within family and school. Finally, the general child's designing 
style such as the degree of attention in details and the child's emotional investment to the process of designing itself or the insistence to sizes, colours, margins etc., could be indicators of positive/negative disposition, social anxiety, indifference in peer company, high persistence to perfectionism, emotional difficulties and specific emotional needs for praise, acceptance and love by the significant others.

\section{Acknowledgements}

This study was conducted in collaboration with the 'Laboratory for Creativity

Development', from 2013 to 2016. Many thanks to all those contributed who worked mostly on a voluntary basis.

\section{References}

Andrews, J. \& Janzen, H. (1988). A global approach for the interpretation of the Kinetic School Drawing (KSD): A quick scoring sheet, reference guide, and rating scale. Psychology in the Schools, 25, 217-238.

Armstrong, D. C. (2004, April). Enhancing visibility of students' learning styles for talent development using actual and ideal school drawings. Paper Presented at American Educational Research Association Annual Convention, San Diego, CA.

Boekaerts, M. (1991). The affective learning process and giftedness. European Journal for High Abitity, 2, 146-160.

Burns, R. C. \& Kaufman, S. H. (1970). Actions styles and symbols in kinetic family drawings (KDF): An interpretative manual. New York, NY: Routledge.

Chandler, L. A., \& Bean, R. M. (1998). The personalities of exemplary teachers. Journal of Research in Education, 8, 64-67.

Freeman, J. (1995). Annotation: Recent studies of giftedness in children. Journal of Child Psychology Psychiatry, 36(4), 531-547.

Frick, P. J., Barry, C. T., \& Kamphaus, R. W. (2010). Clinical assessment of child and adolescent personality and behaviour (3rd edition). New York, NY: Springer.

Fury, G., Carlson, E. A., \& Sroufe, L. A. (1997). Children's representations of attachment relationships in family drawings. Child Development, 68(6), 1154-1164.

Gari, A. Kalanzi-Azizi, A., \& Mylonas, K. (2000). Adaption and motivation of Greek gifted pupils: Exploring some influences of primary schooling. High Abilities Studies, 11(1), 55-68.

Gari, A. \& Tsigri, C. (2009). Charismatiki mathites kai mathisiakes dyskolies sti scholiki koinotita: Diaforetikes anages kai dyskolies [Gifted pupils and learning difficulties at school community: Different needs and difficulties]. Psychology, 16(3), 439-455.

Goldner, L., Edelstein, M., \& Habhush, Y. (2015). A glance at children's family drawings: Associations with children's and parents' hope and attributional style. The Arts in Psychotherapy, 43, 7-15. 
Goldrner, L., \& Scharf, M. (2011). Children's family drawings: A study of attachment, personality, and adjustment. Journal of the American Art Therapy Association, $8(1)$, 11-18.

Grenier, M. E. (1985). Gifted children and other siblings. Gifted Child Quarterly, 29(4), 164-167.

Heath, W. J. (1997). What are the most effective characteristics of teachers of the gifted? (ERIC ED 411 665). Retrieved from https://files.eric.ed.gov/fulltext/ ED411665.pdf

Heller, K. A. (1992). Giftedness research and education of the gifted and talented in Germany. In Mönks, F. J., Katzko M. W., \& Boxtel H. W. (Eds.), Education of the gifted in Europe: Theoretical and research issues (71-86). Assent, The Netherlands: Van Gorcum.

Heller, K. A., Perleth, C., \& Lim, T. K. (2005). The Munich model of giftedness designed to identify and promote gifted students. In R. J. Sternberg \& J. E. Davidson (Eds.), Conseptions of giftedness (pp. 172-197). New York, NY: Cambridge University Press.

Kaplan, N., \& Main, M. (1986). Instructions for the classification of children's family drawings in terms of representation of attachment. Berkeley, CA: University of California.

Kaufman, A. S. \& Harrison, P. L. (1986). Intelligence tests and gifted assessment: What are the positives? Roeper Review, 8, 154-159.

Keirouz, K. S. (1990). Concerns of parents of gifted children: A research review. Gifted Child Quarterly, 34(2), 56-63.

Klepsch, M., \& Logie, L. (1982). Children draw and tell: An introduction to the projective uses of children's human figure drawings. New York, NY: Brunner/Mazel.

Lapidot-Berman, J., \& Oshrat, Z. (2009). Sibling relationships in families with gifted children. Gifted Education International, 25, 36-47.

Leon, K., Wallace, T., \& Rudy, D. (2007). Representations of parent-child alliances in children's family drawings. Social Development, 16(3), 440-459.

Lilienfeld, S. O., Wood, J. M., \& Garb, H. N. (2000). The scientific status of projective techniques. Psychological Science in the Public Interest, 1, 27-66.

Logie, L. (1982). Children draw and tell: An introduction to the projective uses of children's human figure drawings. New York, NY: Brunner/Mazel.

Madigan, S., Ladd, M. \& Goldberg, S. (2003). One picture is worth a thousand words: Children's representations of family as indicators of early attachment. Attachment and Human Development, 5, 19-37.

Mills, C. J (2003). Characteristics of effective teachers of gifted students: Teacher background and personality styles of students. Gifted Child Quarterly, 47(4), 272-281.

Mills, C. J. \& Parker, W. D. (1998). Cognitive-psychological profiles of gifted adolescents from Ireland and the US: Cross-societal comparisons. International Journal of Intercultural Relations, 22, 1-16. 
Mönks, F. J., Van Boxtel, H. W., Roelefs, J. J. W., \& Sanders, M. P. M. (1986). The identification of gifted children in secondary education and a description of their situation in Holland. In K. A. Heller \& J. F. Feldhusen (Eds.), Identifying and nurturing the gifted (pp. 39-65). Toronto, Canada: Hans Huber.

Neihart, M. (2002). Risk and resilience in gifted children: A conceptual framework. In M. Neihart, S. Reis, N. M. Robinson, \& S. M. Moon (Eds.), The social and emotional development of gifted children: What do we know? (pp. 113124). Waco, TX: Prufrock.

Neihart, M., \& Olenchak, F. R. (2002). Creatively gifted children. In M. Neihart, S. Reis, N. M. Robinson, \& S. M. Moon (Eds.), The social and emotional development of gifted children: What do we know? (pp. 165-176). Waco, TX: Prufrock.

Pace, C. S., Zavattini G. C., \& Tambelli, R. (2015). Does family drawing assess attachment representations of late-adopted children? A preliminary report. Child Adolescent Mental Health, 20(1), 26-33.

Olszewski-Kubilius, P., Lee, S.-L., \& Thomson, D. L. (2014). Family environment and social development in gifted students. Gifted Child Quarterly, 58(3), 119-216.

Pianta, R. C., Longmaid, K., \& Ferguson, J. E. (1999). Attachment-based classifications of children's family drawings: Psychometric properties and relations with children's adjustment in kindergarten. Journal of Clinical Child Psychology, 28(2), 244-255.

Post, F. (1994). Creativity and psychopathology: A study of 291 world-famous men. The British Journal of Psychiatry, 165(1), 22-34.

Prout, H., \& Celmer, D. (1984). School drawings and academic achievement: A validity study of kinetic school drawing technique. Psychology in the Schools, 21, 176-180.

Prout, H., \& Phillips, P. (1974). A clinical note: The kinetic school drawing. Psychology in the Schools, 11, 303-306.

Reis, S. M., \& Renzulli, J. S. (2004). Current research on the social and emotional development of gifted and talented students: Good news and future possibilities. Psychology in the Schools, 41, 119-130.

Renzulli, J. S., Reis, S. M., \& Smith, L. M. (1981). The revolving door identification model. Mansfield Centre, CT: Creative Learning Press.

Reynolds, C. R. (1978). A quick-scoring guide to the interpretation of children's kinetic family drawings (KFD). Psychology in the Schools, 16(4), 489-492.

Shore, B. M., Cornell, D. G., Robinson, A., \& Ward, V. S. (1991). Recommended practices in gifted education. New York, NY: Teachers College Press.

Silverman, L. K., \& Kearney, K. (1989). Parents of the extraordinarily gifted. Advanced Development Journal, 1, 41-56.

Singh, J., \& Rossouw, P. J. (2015). Efficacy of drawings as a measure of attachment style and emotional disturbance: An Australian children investigation. International Journal of Neuropsychotherapy, 3(2), 124-130. 
Sisk, D. (1989). Creative teaching of the gifted. New York, NY: McGraw-Hill.

Spigelman, G., Lungs, U., Sweden Spigelman, A., \& Englesson, I. L. (1992). Analysis of family drawings: A Comparison between children from divorce families. Journal of Divorce and Remarriage, 18, 31-54.

Subotnik, R. F., Kubilius, P., \& Worrell, F. C. (2012). A proposed direction forward for gifted education based on psychological science. Gifted Child Quarterly, 56, 176-188.

Vogl, K., \& Preckel, F. (2014). Full-time ability grouping of gifted students: Impacts on social self-concept and school-related attitudes. Gifted Child Quarterly, 58(1), 51-68.

Windecker-Nelson, E., Melson, G. F., \& Moon, S. M. (1997). Intellectually gifted preschoolers' perceived competence: Relations to maternal attitudes, concerns, and support. Gifted Child Quarterly, 41, 4.

Whitlock, M. S., \& DuCette, J. P. (1989). Outstanding and average teachers of the gifted: A comparative study. Gifted Child Quarterly, 33, 15-21.

Wright, J. H., \& McIntyre, M. P. (1982). The family drawing depression scale. Journal of Clinical Psychology, 38(4), 853-861. 



\title{
Teacher Strategies to Motivate Gifted Students: A Multiple Case Study on Teacher Behavior
}

\author{
Greet C. De Boer \\ University of Groningen, The Netherlands \\ g.c.de.boer@rug.nl \\ Marie-Christine J. L. Opdenakker \\ University of Groningen, The Netherlands \\ m.c.j.l.opdenakker@rug.nl \\ Alexander E. M. G. Minnaert \\ University of Groningen, The Netherlands \\ a.e.m.g.minnaert@rug.nl
}

\begin{abstract}
Six experienced teachers of gifted secondary students were studied to gain insight in their teaching strategies and decisions to challenge and motivate gifted students. Based upon self-determination theory, the extent to which teachers meet gifted students' basic psychological needs (competence, autonomy, relatedness) was focused upon. A mixed-methods approach was used by means of in-class observations and video-stimulated recall interviews. All teachers demonstrated a mediocre level of structured teaching strategies, hence meeting students' need for competence. However, a low level of autonomy-supportive and differential teaching strategies was encountered, which might hinder students' motivation over time.
\end{abstract}

Keywords: teacher behaviour, gifted students, learning contexts, motivation, self-determination theory

In literature on giftedness, it is stated that intellectual gifted and talented students have special psychological and learning needs. Hence, they require a differentiated, adaptive curriculum embedded within an optimal learning environment, to maintain their learning motivation and to reach to their potential (Chan, 2001; Cheung \& Hui, 2011; Graffam, 2006; Hertberg-Davis, 2009; Mills, 2003; Sisk, 2009; Tomlinson et al., 2003). The importance of a strong and supportive environment for the development of talent is widely recognized, however, the proposed curricular adaptations do not provide clear guidelines for schools and teachers how to create an optimal motivating learning environment. Researchers within the domain mentioned (Bentley, 2001; Eyre, 2002; Hoogeveen, Van Hell, \& Verhoeven, 2011; Renzulli \& Reis, 2000; VanTassel-Baska, 2006; VanTassel-Baska et al., 2008; Vialle \& Quigley, 
2002) stress the need for compacting and enrichment programs, for tutored learning, for accelerating education, and for additional or extracurricular assignments, within the zone of students' autonomous decision-making in gifted programs, to challenge and motivate gifted students for learning in school. Consequently, teachers of gifted students should differentiate to students' cognitive level and time to learn, provide opportunities for greater complexity and depth in the organization of content, and promote choice and independence in students' learning (Graffam, 2006; Kanevsky, 2011; Little, 2012; Philips \& Lindsay, 2006). Research on educational practice has revealed, though, that special curricula and programs are not necessarily sufficient to improve gifted students' competencies, and to promote their motivation (Colangelo \& Assouline, 2000; Hoogeveen, Van Hell, Mooij, \& Verhoeven, 2004; Hoogeveen, Van Hell, \& Verhoeven, 2005; Little, 2012; VanTassel-Baska, MacFarlane, \& Feng, 2006). It appears as if teachers of gifted students do not meet the overall crucial competencies necessary for both triggering gifted students' motivation, and fulfilling their socioemotional and psychological needs (Chan, 2001; Deci \& Ryan, 2000; Sisk, 2009; VanTassel-Baska, MacFarlane, et al., 2006; Vialle \& Quigley, 2002;), for enhancing their metacognitive skills (Hong, Green, \& Hartzell, 2011), and for monitoring and fostering their academic achievement (Chan, 2001, 2011; Hansen \& Feldhusen, 1994).

Teachers are considered as an important determining factor for students' learning environment, and there is empirical evidence that teachers' planning, decision making, instructional practices and interpersonal relationships influence students' motivation and the degree to which they learn (Chan, 2001; Croft, 2003; Opdenakker \& Minnaert, 2011; Schunk, Pintrich, \& Meece, 2010; Skinner \& Belmont, 1993; VanTassel-Baska et al., 2008). Hence, 'the context and manner in which challenging tasks are presented matter in terms of promoting motivation and engagement for gifted learners' (Little, 2012, p. 697). Accordingly, the question emerged whether teachers - when they differentiate to gifted students' cognitive learning needs - also pay adequate attention to the learning context, and create a motivating learning environment?

The influence of the learning environment on students' motivation in school is also stressed by the Self-Determination Theory (SDT) of Deci and Ryan (2000). In this theory, a set of three innate psychological needs is indicated relevant for students' motivation, (task) engagement, and selfdevelopment: the need for competence, relatedness, and autonomy (Appleton, Christenson, \& Furlong, 2006). In an educational setting, the need for competence 'involves students' experience of efficacy while completing a 
learning task' (Sierens, Vansteenkiste, Goossens, Soenens, \& Dochy, 2009, p. 58). Relatedness concerns students' feelings of belonging to and connection with other persons, such as other students and their teachers. The need for autonomy refers to choice, and the desire to self-organize experience and psychological freedom with regard to one's own behaviour and/or study activities (Deci, Vellerand, Pelletier, \& Ryan, 1991; Sierens et al., 2009). The fulfilment of these three needs is said to represent a necessary condition for students' optimal learning. For that reason, teachers should offer structure - by communicating clear guidelines and expectations about desired outcomes, by providing optimal challenging tasks, by realizing effective instructional support, and by providing 'students with appropriate tools and feedback to promote success and feelings of efficacy' (Niemec \& Ryan, 2009, p. 139) to fulfil students' need for competence. For students' need for relatedness, teachers should create a warm, supportive teacher-student relationship, and provide students a sense of belonging. Students' need for autonomy can be supported by teachers who offer choice and a meaningful reason for learning in school, who avoid controlling language, and who promote active learning, taking into account the differences in learning and development among students. In supporting autonomy, the absence of external rewards, control, and pressure is emphasized (Belmont, Skinner, Wellborn, \& Connell, 1992; Deci \& Ryan, 2000; Opdenakker, 2014; Opdenakker \& Minnaert, 2011; Skinner \& Belmont, 1993). From this point of view, it is interesting to explore to what extent teachers of gifted students present challenging tasks and instruction in this way, and hence, meet the basic psychological needs of gifted students, and consequently, increase students' motivation.

The questions raised are certainly applicable to the context of gifted education in the Netherlands, where - after relatively disappointing results from especially Dutch secondary gifted students at the PISA 2009 international comparative study on reading, mathematics, and science (OECD, 2010; PISA, 2009) - gifted and talented students were identified as a group at risk. Clear empirical indications are found for this group at risk by means of the number of students with early drop out, in the number of underachievers, in the magnitude of students' downward tracking in secondary education, and in the number of students with learning, behavioural, and/or social problems (Minnaert, 2005).

In the Netherlands - as in many other countries - different educational settings, which focus more or less on the cognitive learning needs of gifted and talented students, are realized in secondary education. However, not much is known about the effectiveness of these different settings, and - when they 
are effective - it is unclear what it is that really works, under which conditions it works, and for whom it works. Moreover, it appears that the effectiveness of classrooms settings is judged predominantly by students' cognitive outcomes as markers of quality, with less attention for students' non-cognitive changes in behaviour and for the influence of teacher behaviour on students' outcomes (e.g., Borland, 2003; Coleman, 2014). In addition, research on gifted education and on the qualities, competencies, and skills teachers have to comply with to teach gifted students, is scarce in the Netherlands (Dutch Organization of Scientific Research, 2012; Segers \& Hoogeveen, 2012). Hence, there is limited knowledge what teachers actually do in class to challenge and motivate their gifted students.

Besides, even though teachers acknowledge that gifted students need specific support, and emphasize the importance of a good relationship with their students (De Boer, Brakke, \& Minnaert, 2013), the need for care for gifted and talented students is still often underestimated, and is often considered to be a luxury problem. As a result, the motivation of gifted and talented students does not always seem to be adequately triggered by the learning environment in Dutch secondary education schools (De Boer \& Minnaert, 2011; De Boer, Minnaert, \& Kamphof, 2013; Minnaert, 2005). Consequently, an in-depth investigation of teacher behaviour in classes with gifted students, seems necessary to better understand components crucial for increasing gifted students' motivation. In addition, by emphasizing the influence of the social or educational setting on students' motivation, SDT provides complementary perspectives for gifted education on the links between teacher behaviour and the learning environment created. In view of that, this study on teacher behaviour in classes with gifted students is nested within the SDT frame of reference.

To build on these understandings, we explored what six teachers of gifted secondary education students actually do in their class to challenge and motivate their gifted students. By means of videotaped lessons and recall interviews, teachers were stimulated to reflect on their behaviour, and to explain which factors influenced their decision making. Our special interest was to identify components of the learning environment, which promote gifted students' motivation, and which are supportive for further empirical enquiry into the specification of relevant dimensions of teacher behaviour to motivate gifted students with regard to the SDT frame of reference.

We formulated the following interrelated research questions:

1. To what extent do teachers of gifted students challenge and motivate 
Quantitative

Data collection

(in-class observation*)

Analysis of data

Results

Qualitative

Data collection

(video registration

and video stimulated

recall interview*)

Analysis of data

Figure 1 Visual Diagram of the Study (* data collection in-class observation followed by recall interview within 1 day)

gifted students in their lessons in relation to students' basic psychological needs?

2. How do teachers describe their decision making in relation to motivating teaching strategies (structure, autonomy support, and involvement) and gifted students' motivation for learning at school?

3. To what extent do the results of the in-class teacher observations confirm the results of the video-stimulated recall interviews regarding teachers' decision making?

\section{Method}

For this study we used a triangulation mixed methods design to assess the teacher's behaviour in classes with gifted students (see Figure 1). The triangulation design is a one-phase design in which quantitative and qualitative methods are implemented during the same timeframe and with equal weight (Creswell, 2013). By combining both quantitative and qualitative research on the same topic, this form of research represents an opportunity to better understand a research problem than either research approach alone (Creswell \& Plano Clark, 2007).

In this study we collected quantitative data by using an in-class teacher observation, and qualitative data by means of a video stimulated recall interview with the teacher of the lesson observed. Since the object of the study was to capture teachers' motivating teaching strategies consistent with the SDT framework, a multiple-case study seemed appropriate. A multiple-case study (Baxter \& Jack, 2008) is an excellent way to explore or describe a specific 
phenomenon in context, and thus, for this study, to obtain deeper understanding of teachers' behaviour in classes with gifted students and interactions between teacher and students that promote or hinder gifted students' motivation.

\section{Participants}

Six secondary education teachers, experienced in teaching gifted students, participated in the study on a voluntary base. The teachers stem from two secondary schools with an explicit focus on gifted students. School A is a school with enrichment classes for gifted and talented students, located in a medium-sized town in the middle of the Netherlands. School B is a school with specific policies for gifted education throughout the curriculum, located in a medium-sized industrial city in the east of the Netherlands. We approached the school principal by telephone, explained the purpose and procedure of the study, and asked him to invite teachers for participating in the study. We selected six teachers, based on their expertise in teaching gifted students and their willingness to open their classroom for the purpose of this study. Two teachers from school A and four teachers from school $B$ participated in this study. Three of the teachers were teaching in a junior high class (students aged 12-13), and three in a senior high class (students aged 15-16), at pre-university level, in special classes for gifted and talented students (junior high class), and mixed-ability classes with both gifted and non-gifted students (senior high class). Four of the teachers were teaching a language course - mother language (Dutch), and foreign language (English) - , one teacher math, and one teacher was teaching history (see Table 1 for the descriptives of the teachers).

\section{Procedure}

Three months after the start of the academic school year, we observed the teachers during one lesson in order to set a baseline for what teachers actually do in class. To register teacher behaviour during the lesson observed we filled out a teacher observation form. To explore in-depth teachers' perceptions and thoughts of the way they organized their lesson, we opted for a stimulated recall-interview with the teachers (Baxter \& Jack, 2008; Glaudé, Breetveld, Van den Berg, \& De Bruijn, 2011). In support of the video stimulated recall interview with the teacher, we included the observed lesson on video. Before the recall-interview took place, we inspected the scores of the lesson observed on the completed observation form. Subsequently, we selected elements of the lesson in which the teacher applied teaching strategies consistent with motivational teacher behaviour from gifted education 
Table 1 Descriptives of the Six Participating Teachers

\begin{tabular}{|c|c|c|c|c|c|c|c|c|c|c|c|c|}
\hline \multirow[t]{2}{*}{ Teacher } & \multirow[t]{2}{*}{ Gender } & \multirow[t]{2}{*}{ Age } & \multicolumn{2}{|c|}{ School A } & \multicolumn{2}{|c|}{ School B } & \multicolumn{4}{|c|}{ Domain } & \multicolumn{2}{|c|}{ Class Type } \\
\hline & & & 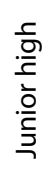 & 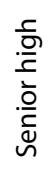 & 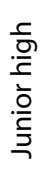 & 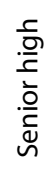 & \begin{tabular}{l}
$\frac{n}{U}$ \\
\multirow{2}{*}{} \\
\end{tabular} & $\begin{array}{l}\frac{\sqrt{n}}{\bar{\sigma}} \\
\frac{5}{\tilde{w}}\end{array}$ & 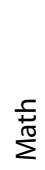 & 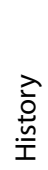 & 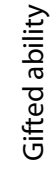 & 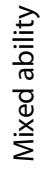 \\
\hline$A$ & female & $<30$ & $x$ & & & $x$ & $x$ & & & & & $x$ \\
\hline B & female & $<30$ & & & $x$ & & & & & $x$ & $x$ & \\
\hline C & male & $<30$ & & & $x$ & & & $x$ & & & $x$ & \\
\hline D & female & $<30$ & & $x$ & & & & $x$ & & & & $x$ \\
\hline $\mathrm{E}$ & male & $>50$ & & & & $x$ & & $x$ & & & & $x$ \\
\hline $\mathrm{F}$ & male & $>30$ & & & & $x$ & & & $x$ & & & $x$ \\
\hline
\end{tabular}

Notes School A: school with enrichment classes for gifted students. School B: school with specific policies for gifted students.

scenarios, and with the SDT frame of reference. Hence, we focused on environmental characteristics of structure, challenge, choice and cognitive differentiation, autonomy-support, and involvement, which were demonstrated by the teacher during the lesson observed. Thereafter, we selected the corresponding fragments from the video images of the lesson where the observed teacher behaviour was visible. We showed the teacher the selected fragments of her/his lesson, and asked her/him to recall what s/he was thinking about at that time, to explain her/his decision and motives for her/his behaviour, and to reflect on the possible effect on gifted students' motivation in the particular situation.

\section{Instruments}

Taking into account the multifactorial character of optimal learning contexts in relation to gifted students' motivation, we used - thoroughly examined - assessment instruments from research on gifted education, and from research regarding the SDT frame of reference.

To assess teacher behaviour, we used an in-class teacher observation form, which is applied in a more extensive longitudinal research project - with three measurement moments - on triggering the motivation of gifted students in secondary education schools (schools, $N=17$; teachers, $N=103$; students, $N=1369$ ) (De Boer, Opdenakker, \& Minnaert, 2013). In developing the teacher observation form, De Boer and colleagues used (a) two well-known teacher observation instruments, comprising important differential instructional approaches for teachers of gifted students:

- the Classroom Observation Scale-Revised (COS-R), an observation in- 
strument for assessing teachers' instructional practice (VanTassel-Baska et al., 2008; VanTassel-Baska, Quek, \& Feng, 2006), and

- the Teacher-Observation Form (TOF), an evaluation instrument for teacher behaviour (Peters \& Gates, 2010),

and, (b) three subscales of the 'Teacher Report Form' from a translated version of the 'Teacher as Social Context Questionnaire' (Belmont et al., 1992; Sierens et al., 2009), comprising motivating teaching strategies according to the SDT framework (Involved, Structured, and Autonomy-supportive teaching strategies).

Both the COS-R, and the TOF have been thoroughly researched and developed, and their validity and reliability have been well documented in the literature (Feldhusen \& Hansen, 1987, 1988; Hansen \& Feldhusen, 1994; VanTassel-Baska et al., 2008; VanTassel-Baska, Quek, \& Feng, 2005; VanTasselBaska, Quek, et al., 2006; Peters \& Gates, 2010).

For their study, De Boer and colleagues have selected and adapted several scales and items from the above mentioned instruments on aspects of structured teacher behaviour, on aspects of autonomy-supportive teacher behaviour, and on aspects of involved teacher behaviour (see Table 2). Sample items include: 'The teacher indicates how the lesson is planned' (structured teacher behaviour), 'The teacher provides opportunities for students to explore and to develop new ideas' (autonomy-supportive teacher behaviour), and 'The teacher is enthusiastic towards her/his students' (involved teacher behaviour). From the three subscales of the 'Teacher Report Form' (Structure, Autonomy Support, and Involvement), sample items include: 'The teacher gives directions to students on how to carry out their assignments' (structure), 'The teacher provides opportunities for students to make choices according to their own interests' (autonomy support), and 'The teacher sets individual students' minds at ease if necessary' (involvement) (see Table 3).

The in-class teacher observation form encompasses 69 items: 29 items for structured teacher behaviour, 30 items for autonomy-supportive teacher behaviour, and 9 items for involved teacher behaviour. Teacher behaviour is assessed by a four-point scale, which ranges from 'not observed' to '(almost) perfectly executed:'

o 'Not observed during this lesson,' that is, the teacher does not show the behaviour during the observed lesson.

1 'Sometimes observed during this lesson,' that is, the teacher shows the behaviour occasionally during the observed lesson. 
Table 2 Teacher Observation Form: Examples of Selected and Adapted Items from Different Instruments and Their Relation with SDT

\begin{tabular}{|c|c|c|c|}
\hline $\begin{array}{l}\text { Teacher be- } \\
\text { haviour }\end{array}$ & Instrument & Original item & Adapted item \\
\hline \multirow[t]{2}{*}{ Structure } & COS-r & $\begin{array}{l}\text { Teacher interview question: } \\
\text { 'What content will you cover in } \\
\text { your subsequent lesson?' } \\
\text { The teacher set high expecta- } \\
\text { tions for students' performance. }\end{array}$ & $\begin{array}{l}\text { The teacher indicates which } \\
\text { subjects will be covered in next } \\
\text { lessons. } \\
\text { The teacher stresses to students } \\
\text { to excel in learning. }\end{array}$ \\
\hline & TOF & $\begin{array}{l}\text { Lessons show a sense of plan- } \\
\text { ning, with flexibility. } \\
\text { Instructor utilizes pre- } \\
\text { assessment to prevent redun- } \\
\text { dancy. }\end{array}$ & $\begin{array}{l}\text { The teacher indicates how the } \\
\text { lesson is planned. } \\
\text { The teacher utilizes students' } \\
\text { existing knowledge to prevent } \\
\text { repetition. }\end{array}$ \\
\hline \multirow[t]{2}{*}{$\begin{array}{l}\text { Autonomy } \\
\text { Support }\end{array}$} & COS-r & $\begin{array}{l}\text { The teacher had students re- } \\
\text { flect on what they had learned. } \\
\text { The teacher provides opportu- } \\
\text { nities for students to develop } \\
\text { and elaborate on their ideas. }\end{array}$ & $\begin{array}{l}\text { The teacher asks students to re- } \\
\text { flect on their learning process. } \\
\text { The teacher provides opportu- } \\
\text { nities for students to explore } \\
\text { and to develop new ideas. }\end{array}$ \\
\hline & TOF & $\begin{array}{l}\text { The teacher encourages stu- } \\
\text { dents' enthusiasm and persis- } \\
\text { tence. } \\
\text { Instructor avoids unnecessary } \\
\text { repetition and drill. }\end{array}$ & $\begin{array}{l}\text { The teacher encourages stu- } \\
\text { dents' enthusiasm and perse- } \\
\text { verance. } \\
\text { The teacher prevents unneces- } \\
\text { sary repetition and memoriza- } \\
\text { tion. }\end{array}$ \\
\hline \multirow[t]{2}{*}{ Involvement } & COS-r & $\begin{array}{l}\text { The teacher encourages stu- } \\
\text { dents to express their thoughts. }\end{array}$ & $\begin{array}{l}\text { The teacher encourages stu- } \\
\text { dents. }\end{array}$ \\
\hline & TOF & $\begin{array}{l}\text { Teacher shows energy and en- } \\
\text { thusiasm. } \\
\text { Teacher and students show mu- } \\
\text { tual respect. }\end{array}$ & $\begin{array}{l}\text { The teacher is enthusiastic to- } \\
\text { wards his/her students. } \\
\text { The teacher shows his/her } \\
\text { knowledge about the students. }\end{array}$ \\
\hline
\end{tabular}

2 'Belongs to the teacher's behaviour', that is, the teacher shows the behaviour regularly during the observed lesson.

3 '(Almost) perfectly executed, the teacher is an expert,' that is, the behaviour is illustrative of the teacher and an integral part of the teacher's behaviour during the observed lesson.

\section{Factor Analysis and Reliability of the Teacher Observation Form}

Given the complexity of combining existing reliable instruments into a new assessment instrument for assessing behaviour of teachers of gifted students through the lens of SDT, the importance of retaining only those items and scales necessary for an understanding of teacher behaviour within the 
Table 3 Examples of Selected and Adapted Items: Teacher Report of Teacher Context (TASC)

\begin{tabular}{|c|c|c|}
\hline \multirow[t]{4}{*}{$\begin{array}{l}\text { Autonomy } \\
\text { support }\end{array}$} & Selected item & $\begin{array}{l}\text { I try to give these students a lot of choices about classroom } \\
\text { assignments }\end{array}$ \\
\hline & Adapted form & $\begin{array}{l}\text { The teacher provides opportunities for students to make } \\
\text { choices of their own interest }\end{array}$ \\
\hline & Selected item & $\begin{array}{l}\text { I can't let this student do things his/her own way (negative } \\
\text { valence - revised scored) }\end{array}$ \\
\hline & Adapted form & $\begin{array}{l}\text { The teacher creates opportunities for students to process in } \\
\text { their own way (positive valence) }\end{array}$ \\
\hline \multirow[t]{4}{*}{ Structure } & Selected item & I talk with this student about my expectations for him/her \\
\hline & Adapted form & $\begin{array}{l}\text { The teacher indicates possible efforts for students to accom- } \\
\text { plish the task }\end{array}$ \\
\hline & Selected item & I show this student different ways to solve a problem \\
\hline & Adapted form & $\begin{array}{l}\text { The teacher gives directions to students how to progress } \\
\text { their assignments }\end{array}$ \\
\hline \multirow[t]{2}{*}{ Involvement } & Selected item & This student can count on me to be there for him/her \\
\hline & Adapted form & The teacher sets individual students' mind at ease if necessary \\
\hline
\end{tabular}

SDT framework, is stressed (De Boer et al., 2013). Hence, the researchers performed exploratory factor analyses (EFA) with principal components on the items selected, which revealed the existence of three factors (20 items were eliminated because they failed to load substantially on any factor).

Factor 1 is defined as global instructional strategies. Items loading on this factor represent teacher behaviour which is explained as fairly general instructional behaviour, with characteristics of structured teaching behaviour like, planning the lesson, offering structured choice, and communicating clearly expectations, as well as supporting students with their task, and showing involvement with the students. Example items include: 'The teacher encourages problem-solving and independent learning-strategies,' and 'shows confidence in the abilities of the students.'

Teaching strategies loading on Factor 2 are identified as autonomy-supportive teaching strategies. Sample items include: 'The teacher activates individual students to make challenging assignments', and 'creates opportunities for students to process in their own way.'

Items loading on factor 3 represent teaching strategies which are defined as specific differential teaching strategies. Sample items include: 'The teacher reveals the differences between students in relation to the students' levels, time spent on learning, and planning', and 'The teacher differentiates to the cognitive level of students,' and 'supports students by assignments different from the regular program.' These specific differential teaching strategies, 
therefore, represent a combination of teachers offering structured choice, supporting students during their assignments, and of teachers' involvement at students by showing interest in individual differences between students.

Cronbach's alphas (range for the three measurement moments in the encompassing research project) were, respectively: 0.81 to 0.86 for factor 1 ( 27 items), 0.80 to 0.85 for factor 2 ( 12 items), and 0.76 to 0.80 for factor 3 ( 10 items).

\section{Teachers' Perception of Their Instructional Behaviour}

Teachers' perceptions, decisions and reasoning about their instructional behaviour was assessed by a video-stimulated recall interview with the teacher (see Procedure). As mentioned earlier, we selected several fragments consistent with gifted education scenarios and the SDT frame of reference for the recall-interview with the teacher. For structured teacher behaviour examples included: the teacher wrote a lesson plan on the blackboard, gave clear instruction on the subject, explained her/his expectations to the students, triggered some individual students at their cognitive level, and offered relevant feedback on students' task related behaviour. For autonomy-supportive teacher behaviour we selected fragments such as the teacher offered students possibilities to choose other tasks, or to work in their own pace, and offered extra support at the student's request. For involved teacher behaviour we included fragments such as the teacher greeted her/his students when they came into the classroom, engaged all students by learning activities and responded to them in a positive way, walked around and had social talks with students.

The selected fragments were the starting point of the recall interview with the teacher. We showed the fragments of the lesson observed, and we stimulated the teacher to recall her/his thoughts for that particular moment, her/his perception and reasoning for the behaviour, and also what s/he expected to be the effect of her/his behaviour on students' motivation and task engagement. We recorded the conversations with the teachers on tape, and transcribed those afterwards.

Consistent with the triangulation mixed methods design, we computed descriptive statistics for the quantitative data from the lesson observed of each teacher, using the Statistical Package for the Social Sciences (SPSS). We analysed the qualitative data of the video stimulated recall interview with the teachers on the bases of content. Finally, for the purpose of the interpretation of the data, we merged the two data sets, and described our findings in the discussion section. 
Table 4 Descriptive Statistics of Observed in-Class Teacher Behaviour

\begin{tabular}{lrrrr}
\hline Scales teacher observation form & $\min$ & $\max$ & $M$ & $S D$ \\
\hline Global teaching strategies & 1.30 & 1.78 & 1.48 & 0.22 \\
Autonomy-supportive teaching strategies & 0.29 & 1.17 & 0.79 & 0.34 \\
Differential teaching strategies & 0.00 & 1.80 & 0.65 & 0.64 \\
\hline
\end{tabular}

Notes Scores refer to a four-point scale (0-3).

\section{Results}

In the following sections we present the results of each of our research questions. First, we present the results of the in-class observations of the six teachers. Second, we present the results of the recall interviews combined for the six teachers, and thematically organized.

\section{Teacher Behaviour Observed in Classes with Gifted Students}

To explore in depth what teachers of gifted secondary education students actual do in class regarding motivating teaching strategies from SDT, we observed six teachers during one lesson on the use of structured, autonomysupportive, and involved teaching strategies. In Table 4, we present the results of our observations of teachers' behaviour during the lesson observed.

With a mean score of 1.48 on factor 1 of the observation form, global teaching strategies, we observed that the participating teachers, by and large, planned the lesson observed in an organized, and structured way, although there is room for improvement. We explicated the global strategies as general, basic teaching strategies applicable for all students, such as the teacher demonstrates her/his knowledge about her/his students, indicates possible efforts for students to complete a task, stresses students to excel in learning, responds to her/his students in a responsive way, and requests students how they solved a problem. According to SDT, teachers who perform these strategies fulfil students' need for competence, and to some extent, their need for autonomy and relatedness. Compared with the global teaching strategies, we noticed that the teachers demonstrated substantially less autonomysupportive and differential teaching strategies in the lesson observed with mean scores of 0.79 and 0.65 respectively. In SDT it is stated that both structured and autonomy-supportive teacher behaviour predict students' motivation across the school year.

In Table 5 we present the results of the in-class observations of each of the six individual teachers. We observed that all teachers showed characteristics of a structured teaching approach during the lesson observed, resulting in a mediocre score on the four-point scale scores for global teaching strate- 
gies. Regarding students' basic need satisfaction, each individual teacher, therefore, seemed to meet students' need for competence to a reasonable extent. Taking into account the different teaching strategies within this scale, each teacher also seemed to meet students' need for relatedness and, hence, could have achieved feelings of choice and autonomy for her/his students during this specific lesson. We observed autonomy-supportive teaching strategies only occasionally during the observed lessons, resulting in very low to low mean scores ranging from 0.29 to 1.17. SDT stresses that learning environments that hinder feelings of autonomy of the students can produce low levels of self-determination and, therefore, influence students' intrinsic learning motivation in a negative way. Therefore, these teachers seldom showed characteristics of teachers to fully meet students' need for autonomy.

Our observations of differential teaching strategies, the third scale, revealed very huge differences between the six teachers, with a mean score of 1.80 for teacher $B$ and a mean score of 0.00 for teacher A. The teaching strategies of scale three pointed toward teachers who take into account differences between students regarding students' level, time for learning and planning. With these specific differential teaching strategies, teachers offer students some choice, support them during their assignments, and also show involvement with their students by being orientated towards individual students. Hence, teacher B (with an observed score of 1.80 on the third scale, and scores of 1.35 and 0.92 on the first and second scale) could be considered as the teacher of our sample who best met the basic psychological needs of her students, and differentiated according to those needs during this specific lesson. With the observed mean scores of 1.74 and 1.17 on global teaching strategies and autonomy-supportive teaching strategies, respectively, teacher A sometimes demonstrated a combination of teaching strategies, which could be considered supportive for students' basic needs for competence and autonomy, but the absence of differential teaching strategies is undoubtedly worrisome.

\section{Teachers' Perception of Their Own Instructional Behaviour and Effects on Students' Motivation}

We were interested whether teachers acknowledged the importance of motivational teaching strategies on gifted students' basic need satisfaction, motivation and task engagement in learning in school, and, whether teachers when they looked at their own behaviour on the video fragments of the lesson observed - recognized the influence of their own behaviour on students' 
Table 5 Mean scores of individual teachers' teaching strategies

\begin{tabular}{llll}
\hline Teacher & $\begin{array}{l}\text { Global teaching } \\
\text { strategies }\end{array}$ & $\begin{array}{l}\text { Autonomy- } \\
\text { supportive strategies }\end{array}$ & $\begin{array}{l}\text { Differential teaching } \\
\text { strategies }\end{array}$ \\
\hline A & 1.74 & 1.17 & 0.00 \\
B & 1.35 & 0.92 & 1.80 \\
C & 1.78 & 1.13 & 0.70 \\
D & 1.35 & 0.63 & 0.80 \\
E & 1.37 & 0.58 & 0.20 \\
F & 1.30 & 0.29 & 0.40 \\
\hline
\end{tabular}

Notes Scores refer to a four-point scale (o-3).

motivation and task engagement. Therefore, we discussed with each teacher several fragments of required teacher behaviour to challenge and motivate gifted students, and to meet students' basic needs.

Every lesson observed included a short introduction, with an explanation of how the teacher had planned the lesson. Several teachers wrote the planning on the blackboard and discussed this with their students. The introduction was followed by instruction on the subject or an assignment for the students. Students then went to work, individually or in groups. The teacher walked around and offered support to the students working on their assignments. The lesson ended with some task-relevant feedback on students' taskrelated behaviour and performance, or instruction for homework as a mindful preparation of the upcoming lesson.

During the lessons observed we noticed that all six teachers showed personal involvement with their students, organized their lesson in a structured way, and supported the students when they completed their tasks. Further on, we noticed that the teachers - though they experienced that they had enhanced their students' engagement in an assignment - were not convinced about the influence of their own behaviour on the motivation of their students in terms of task engagement and learning in school. They underlined the importance to challenge gifted students, and to differentiate at gifted students' cognitive level and time to learn, but argued that the amount of students in one class, an imposed curriculum, and pressure toward specified learning results, suppress their possibilities for differentiation. Besides, we noticed that each of the six teachers was not knowledgeable about motivational theories, such as SDT, in relation to creating a more optimal learning environment to challenge and motivate their gifted students. We discuss some examples of the individual interviews with the teachers, and their decision making. 


\section{Structured Teaching Behaviour}

We perceived that all teachers demonstrated structured teaching strategies during the lesson observed. Five of the six teachers presented on the blackboard how they had planned this lesson. Some of these teachers discussed the lesson plan with their students. We also perceived that teachers provided students with help in engaging in a task, explained to students how to accomplish goals, gave competence-relevant feedback, and expressed their confidence in students' abilities.

Teacher B: 'I always write the lesson program on the blackboard and I like to refer to it during lesson. So I can check the progress of the lesson. During my training as a teacher I learned that it is important to give structure, especially when students experience some problems in the autistic spectrum.'

Teacher C: 'I always explain to my students how a lesson is planned and organized. Then they know what they can expect, and they can estimate for themselves how involved they will be with the learning activities. It activates them, and it does help them to get focused, because different activities are classified. Knowing what they can expect helps them to feel comfortable, at ease.'

Teacher D: 'Some weeks ago I started to work with "Choice Menu." I work with learning goals for every week, and for several periods during the school year. On the interactive whiteboard I project what the learning goals are for this period, and I discuss this with my students. I noticed a huge difference between students, so now I explain to them what they need to know, the learning goals, and different ways to learn it. Then they can choose for themselves what they think they need to study'

Teacher B: 'If students are enthusiastic and answer before their turn, I do not want to discipline or control them in a direct way, because next time, maybe they won't answer at all. So in a friendly, responsive way l let them know what the rules are but I also let them know that they gave a good answer. I think by giving feedback in a responsive way students are more engaged with my lessons.'

\section{Autonomy-Supportive and Differential Teaching Strategies}

In every lesson, students spent some time working on an assignment. However, the teachers showed only some aspects of choice and autonomy support. Some examples are: the teacher provided instruction consistent with students' interest, offered students choice in tasks they could do, time needed 
to accomplish a task, and with whom they work together, provided students with support while working on assignments, and suggested what to do if they finished a task or needed extra support.

Teacher F: 'I sped up because I wanted to hold their attention. On the other hand, I had to pay attention to the students who could not keep up. Therefore, I suggested these students to write a sign on their stencil if they had questions. Then, when I walked around, I knew they needed extra support.'

Teacher E: 'Sometimes students are insecure about their own skills. Then I prefer to let them practice together, let them compare solutions with each other, and learn from each other. I offer support when necessary. I think they learn better this way, because it's a result of their own efforts.'

Teacher F: 'All students are allowed to choose other tasks besides the regular ones. The method I use provides differential tasks at a more complex and challenging level. I stimulate the highly gifted students to also take on those tasks, especially when they have finished the other tasks. Otherwise, they do not do anything when they have finished.'

Teacher A: 'I think it's a great luxury to be able to show students some videos, and this was a really exciting movie for them. And if they [the students] have to do a project about this theme, then they are very interested and show a lot of effort. And this is something they like very much. When you [as a teacher] has started doing this, the students repeatedly ask for videos or YouTube films.'

Teacher B: 'I showed this movie because it supports students to imagine how it was to live in that time. So they understood what was going on in those days. Besides, they find it really interesting and it motivates them.

\section{Involved Teacher Behaviour}

During the observed lesson we perceived that all six teachers provided a warm social environment in their classroom, related well to their students, showed involvement with their students, and gave the impression 'to be there' if their students needed them. Some teachers greeted their students when they entered the classroom, and had social talks with their students before they started the lesson.

Teacher B: 'For me it's important to see how the students enter my classroom. Are they very excited and happy, or maybe a little bit sad? Then I can talk to them before I start my lesson and correct misbehaviour, if necessary, or make sure they feel comfortable.' 
Teacher C: 'The first lessons of every day, I want to observe how students behave when they come into my classroom. I want to see the expression on their faces, and how they behave before they arrive at my lesson.'

Teacher E. When students entered the classroom, this teacher greeted his students, and then he walked around, talked with students, joked with them, showed pleasure in being with the students, and explained his behaviour as follows: 'I like doing this. As a teacher you want to have some relationship with your students. This is quite different from the time I was a student. In those days, we entered the classroom really quietly and didn't talk at all. But as a teacher nowadays you do not expect this from your students anymore. And, well, I really like my connections with the students.'

Teacher $D$. This teacher explained that she always socialized with her students before starting her lesson. She explained: Well, contact with your students, that's the basis. Students, even of this age $(15,16$ years of age) - and maybe this is really a little bit odd to say - also work for you! And considering that this is a pre-university class, yes! You have a little chat with them, you know, and then they go to work for you! It is very interesting how this works. Of course, they work for themselves, but that bond you have with them, and taking some moments to socialize with them, that is really important!

Teacher $E$. When teaching, the teacher used examples from real life, taking into account students' interests, their ages, and what he had experienced himself at their age. His motives for demonstrating personal involvement with his students were: 'I think that a personal relationship with my students is very important. And I am convinced that students at this age are not just engaged with their study but also with personal relationships. Students who have a good relationship with their teacher will perform better.'

\section{Discussion}

This study, involving six exemplary teachers of gifted secondary education students, was performed in order to explore in-depth what teachers of gifted students in the Netherlands actually do in class to challenge and motivate their gifted students. We used the SDT frame of reference in order to identify components of the learning environment, which could promote gifted students' motivation, and support further empirical enquiry into the specification of relevant dimensions of teacher behaviour to motivate gifted students.

We found that the teachers, who took part in this study, planned their lessons in a rather organized and structured way, and showed knowledge 
about and involvement with their students. Therefore, they met their students' need for competence and relatedness in the lesson observed. However, during the lesson observed, the teachers showed a low level of skills with reference to differentiation, and hence, at least, hindered students' need for autonomy in learning. Although teachers permitted students some freedom in choosing different tasks, and in working on other assignments, the way they made choice available, and/or offered differential and challenging tasks, corresponded to characteristics of structured teaching according to SDT, such as teachers providing optimal challenging tasks and effective instructional support at the level of the student. It looks as if the teachers were predominantly focused on keeping students 'working' by organizing learning tasks for them, and, in so doing, maybe unconsciously, neglecting opportunities for the students to make choices on their own. In SDT, it is stated that offering structure without an autonomous supportive interpersonal context could result in introjected self-regulation or motivation on the part of students (Deci, Eghrari, Patrick, \& Leone, 1994). Since introjected motivation is considered a controlling form of motivation, students' interest in learning in school can decrease over time (Reeve, 2006). Moreover, Garn and Jolly (2014) found that providing choice, by means of structure and autonomy support, was identified as motivating by high-ability students.

During the video-stimulated recall interviews with the teachers, we verified that most teachers emphasized the importance of a well-planned lesson. They acknowledged the effect of well-organized lessons on students feeling competent and at ease. Nevertheless, they seemed to be less aware of the effects of how they organized their lesson on students' motivation and task engagement. We understood that they were not knowledgeable about the importance of how they taught, communicated their expectations, and provided support/help on students' learning motivation (see also Reeve, Jang, Carrell, Jeon, \& Barch, 2004). All six teachers, though, stressed the importance of a good teacher-student relationship and were well informed about the effects of a warm, social class environment on students' feelings of well-being and their learning performance. Ryan and Deci (2000) have specified that the need for relatedness, and feeling connected with others, is essential for students' positive task-related behaviour and their performance. Researchers in the field of giftedness also emphasize the importance of a positive teacherstudent relationship, and stress that the way teachers present challenging tasks, and support their students matters in terms of students' motivation and engagement with the material (Little, 2012; VanTassel-Baska et al., 2006; Vialle \& Quigley, 2002).

Taken together, as a theoretical framework for investigating characteris- 
tics of an optimal learning environment for gifted students, SDT seems effective in revealing what teachers actually do in class to challenge and motivate gifted students. The results of this small-scale study cannot be generalized to teacher behaviour for gifted students in general. Nevertheless, the results reveal several clear implications of teacher behaviour and characteristics of the learning environment the teacher creates, regarding the extent to which teachers meet gifted students' basic psychological needs. Hence, in order to investigate whether teachers are providing an optimal motivating and supportive learning environment for their gifted students, research with a self-determination perspective also seems valuable for understanding gifted students' learning needs. Research on the development of gifted students' motivation in class along the motivation continuum of SDT is scarce (see also Garn \& Jolly, 2014), as is research on the relationship between gifted students' motivation and teachers' instructional behaviour through the lens of SDT (Clinkenbeard, 2012). Hence, further research on students' perceptions of teacher behaviour is required to investigate the relationship between teacher behaviour and gifted students' motivation, their motivational development during a school year, and their motivation for different subject-matters. Supplementary in-depth studies focusing on how teachers may contribute to gifted students' basic need satisfaction can be supportive in developing clear guidelines for teachers on how to optimize the learning environment for gifted students and how to support them in achieving their capability.

\section{Conclusion}

Self-determination theory framework seems effective in revealing what teachers actually do in class to challenge and motivate gifted students. This theoretical framework is of added value to investigate the characteristics of optimal learning environments conducive for the gifted. Based on inclass observations, we noticed that teachers generally met their students' need for competence and relatedness, but run short of obtaining a sufficient level of differentiation and to meet students' need for autonomous learning. In-depth interviews revealed that teachers stressed the importance of well-planned lessons and a good teacher-student relationship, but were less aware of how they could actually contribute to students' motivation and task engagement.

\section{Acknowledgements}

This case study is part of an ongoing and more extensive research project on triggering the motivation of gifted students in secondary education schools, 
under grant from the Dutch Organization for Scientific Research (NWO 411-12607).

\section{References}

Appleton, J. J., Christenson, S. L., \& Furlong, M. J. (2006). Students' engagement with school: Critical conceptual and methodological issues of the construct. Psychology in the Schools, 45, 369-386.

Baxter, P., \& Jack, S. (2008). Qualitative case study methodology: Study design and implementation for novice researchers. The Qualitative Report, 13(4), 544-559.

Belmont, M., Skinner, E., Wellborn, J., \& Connell, J. (1992). Teacher as social context (TASC), two measures of teacher provision of involvement, structure and autonomy support (Technical Report). New York, NY: University of Rochester.

Bentley, R. (2001). Curriculum development and process in mainstream classrooms. In M. J. Stopper (Ed.), Meeting the social and emotional needs of gifted and talented children (pp. 12-36). London, NY: David Fulton.

Borland, J. H. (2003). Evaluating gifted programs: A broader perspective. In N. Colangelo \& G. A. Davis (Eds.), Handbook of gifted education (pp. 293-307). Boston, MA: Pearson Education.

Chan, D. W. (2001). Characteristics and competencies of teachers of gifted learners: The Hong Kong teacher perspective. Roeper Review, 23(4), 197202.

Chan, D. W. (2011). Characteristics and competencies of teachers of gifted learners: The Hong Kong student perspective. Roeper Review, 33(3), 160-169.

Cheung, H. Y., \& Hui, S. K. F. (2011). Competencies and characteristics for teaching gifted students: A comparative study of Beijing and Hong Kong teachers. Gifted Child Quarterly, 55, 139-148.

Clinkenbeard, P. R. (2012). Motivation and gifted students: Implications of theory and research. Psychology in Schools, 49(7), 622-630.

Colangelo, N., \& Assouline, S. G. (2000). Counseling gifted students. In K. H. Heller, F. J. Mönks, R. J. Sternberg, \& R. F. Subotnik (Eds.), International handbook of giftedness and talent (pp. 595-607). Oxford, England: Elsevier.

Coleman, L. J. (2014). The power of specialized educational environments in the development of giftedness: The need for research on social context. Journal for the Education of the Gifted, 37(1), 70-80.

Creswell, J. W. (2013). Steps in conducting a scholarly mixed methods study (DBER Speaker Series No. 48). Retrieved from http://digitalcommons.unl.edu/ dberspeakers $/ 48$

Creswell, J. W., \& Plano Clark, V. L. (2007). Designing and conducting mixed methods research. Thousand Oaks, CA: Sage.

Croft, L. J. (2003). Teachers of the gifted: Gifted teachers. In N. Colangelo \& G. A. 
Davis (Eds.), Handbook of gifted education (pp. 558-571). Boston, MA: Pearson.

De Boer, G. C., \& Minnaert, A. E. M. G. (2011). Scholen profileren zich tot Begaafdheidsprofielschool: De ontwikkeling op scholen aan de hand van een zelfbeoordeling [Schools with a gifted profile: School development based on a self-assessment instrument] (Research report). Groningen, The Netherlands: University of Groningen.

De Boer, G. C., Opdenakker, M. C. J. L., \& Minnaert, A. E. M. G. (2013). The development of an in-class teacher observation form to assess differentiation and motivation of gifted students (Internal manuscript). Groningen, The Netherlands: University of Groningen.

De Boer, G. C., Minnaert, A. E. M. G., \& Kamphof, G. (2013). Gifted education in the Netherlands. Journal for the Education of the Gifted, 36(1), 133-150.

De Boer, G. C., Brakke, J. S., \& Minnaert, A. E. M. G. (2013). Scholen profileren zich tot Begaafdheidsprofielschool: Docentcompetenties en mate van tevredenheid over het begaafdheidsprofiel van de school [Schools with a gifted profile: Teacher competencies, and level of satisfaction about the gifted profile] (Research report). Groningen, the Netherlands: University of Groningen.

Deci, E. L., Eghrari, H., Patrick, B., \& Leone, D. (1994). Facilitating internalization: The self-determination theory perspective. Journal of Personality, 62(1) 119142.

Deci, E. L., \& Ryan, R. M. (2000). The 'what' and 'why' of goal pursuits: Human needs and the self-determination of behaviour. Psychological Inquiry, 11, 227-268.

Deci, E. L., Vallerand, R. J., Pelletier, L. G., \& Ryan, R. M. (1991). Motivation and education: The self-determination perspective. Educational Psychologist, 26(4), 325-346.

Eyre, D. (2002). Effective schooling for the gifted and talented: A school-wide approach to the gifted and talented. In D. Eyre, \& H. Lowe (Eds.), Curriculum provision for the gifted and talented in the secondary school (pp. 1-26). London, England: David Fulton.

Feldhusen, J., \& Hansen, J. (1987). Selecting and training teachers to work with the gifted in a Saturday program. Gifted Education International, 4(1), 8294.

Feldhusen, J., \& Hansen, J. (1988). Teachers of the gifted: Preparation and supervision. Gifted Education International, 5(2), 84-89.

Garn, A. C. \& Jolly, J. L. (2014). High ability students' voice on learning motivation. Journal of Advanced Academics, 25(1), 7-24.

Graffam, B. (2006). A case study of teachers of gifted learners: Moving from prescribed practice to described practitioners. Gifted Child Quarterly, 50, 119-131. 
Glaudé, M., Breetveld, I., van den Berg, J., \& de Bruijn, E. (2011). Pedagogischdidactisch handelen van docenten in het middelbaar beroepsonderwijs: Beschouwing van de stimulated recall-methode. [Pedagogical-didactic teacher behaviour in secondary vocational education: Contemplation of the stimulated-recall method]. 's-Hertogenbosch, The Netherlands: ECBO.

Hansen, J., \& Feldhusen, J. (1994). Comparison of trained and untrained teachers of gifted students. Gifted Child Quarterly, 38(3), 115-121.

Hertberg-Davis, H. (2009). Myth 7: Differentiation in the regular classroom is equivalent to gifted programs and is sufficient; Classroom teachers have the time, the skill, and the will to differentiate adequately. Gifted Child Quarterly, 53(4), 251-253.

Hoogeveen, L., Hell, J. G. van, Mooij, T., \& Verhoeven, L. (2004). Onderwijsaanpassingen voor hoogbegaafde leerlingen: Meta-analyses en overzicht van internationaal onderzoek [Educational adjustments for gifted students: Meta-analyses and survey of international research]. Nijmegen, The Netherlands: Radboud University.

Hoogeveen, L., Van Hell, J. G., \& Verhoeven, L. (2005). Teacher attitudes toward accelerated students in the Netherlands. Journal for the Education of the Gifted, 29(1), 30-59.

Hoogeveen, L., Van Hell, J. G., \& Verhoeven, L. (2011). Social-emotional characteristics of gifted accelerated and non-accelerated students. British Journal of Educational Psychology, 82(4), 585-605.

Hong, E., Greene, M., \& Hartzell, S. (2011). Cognitive and motivational characteristics of elementary teachers in general education classrooms and in gifted programs. Gifted Child Quarterly, 55(4), 250-264.

Kanevsky, L. (2011). Deferential differentiation: What types of differentiation do students want? Gifted Child Quarterly, 55(4), 279-299.

Little, C. A. (2012). Curriculum as motivation for gifted students. Psychology in Schools, 49(7), 695-705.

Mills, C. J. (2003). Characteristics of effective teachers of gifted students: Teacher background and personality styles of students. Gifted Child Quarterly, 47(4), 272-281.

Minnaert, A. E. M. G. (2005). Maakt het verschil? Over onderwijskundige en orthopedagogische zorg voor leerlingen in het onderwijs [Does it make a difference? About educational and special educational needs for students in education]. In E. J. Knorth, A. E. M. G. Minnaert \& A. J. J. M. Ruijssenaars (Eds.), Verschillen onderscheiden: Orthopedagogische hulpverlening en begeleiding bij problematische opvoedings en onderwijsleersituaties (pp. 43-62). Utrecht, The Netherlands: Agiel.

Niemiec, C. P., \& Ryan, R. M. (2009). Autonomy, competence, and relatedness in the classroom: Applying self-determination theory to educational practice. Theory and Research in Education, 7(2), 133-144. 
Dutch Organization of Scientific Research. (2012). Excellence in primary, secondary, and higher education. Retrieved from http://nwo.nl/nwohome.nsf /pages/NWOP_8YPFLD

OECD. (2010). PISA 2009 results: What students know and can do. Students performance in reading, mathematics and science. Paris: OECD.

Opdenakker, M. C. J. L. (2014). Leerkracht-leerlingrelaties vanuit een motivationeel perspectief [Teacher-student relationships from a motivational perspective]. Pedagogische Studiën, 91, 332-351.

Opdenakker, M.-C., \& Minnaert, A. (2011). Relationship between learning environment characteristics and academic engagement. Psychological Reports, 109, 259-284.

Peters, S. J., \& Gates, J. C. (2010). The teacher observation form: Revision and updates. Gifted Child Quarterly, 54(3), 179-188.

Philips, N., \& Lindsay, G. (2006). Motivation in gifted students. High Ability Studies, 17(1), 57-73.

PISA. (2009). PISA 2009 assessment framework: Key competencies in reading, mathematics and science. Paris, France: OECD.

Reeve, J. (2006). Teachers as facilitators: What autonomy-supportive teachers do and why their students benefit. Elementary School Journal, 106(3), 225236.

Reeve, J., Jang, H., Carrell, D., Jeon, S., \& Barch, J. (2004). Enhancing students' engagement by increasing teachers' autonomy support. Motivation and Emotion, 28(2), 147-169.

Renzulli, J. S., \& Reis, S. M. (2000). The school wide enrichment model. In K. H. Heller, F. J. Mönks, R. J. Sternberg, \& R. F. Subotnik (Eds.), International handbook of giftedness and talent (pp. 367-382). Oxford, England: Elsevier.

Ryan, R. M., \& Deci, E. L. (2000). Self-determination theory and the facilitation of intrinsic motivation, social development, and well-being. American Psychologist, 55(1), 68-78.

Schunk, D. H., Pintrich, P. R., \& Meece, J. L. (2010). Motivation in education: Theory, research, and applications (3rd ed.). Hoboken, NJ: Pearson Education.

Segers, E., \& Hoogeveen, L. (2012). Programmeringsstudie excellentieonderzoek in primair, voortgezet en hoger onderwijs [Programming study on excellence research in primary, secondary, and higher education]. Nijmegen, The Netherlands: Behavioral Science Institute.

Sisk, D. (2009). Myth 13: The regular classroom teacher can 'go it alone.' Gifted Child Quarterly, 53(4), 269-271.

Sierens, E., Vansteenkiste, M., Goossens, L., Soenens, B., \& Dochy, F. (2009). The synergistic relationship of perceived autonomy support and structure in the prediction of self-regulated learning. British Journal of Educational Psychology, 79, 57-68.

Skinner, E. A., \& Belmont, M. J. (1993). Motivation in the classroom: Reciprocal 
effect of teacher behaviour and student engagement across the school year. Journal of Educational Psychology, 85(4), 571-581.

Tomlinson, C. A., Brighton, C., Hertberg, H., Callahan, C. M., Moon, T. R., Brimijoin, K., \& Reynolds, T. (2003). Differentiating instruction in response to student readiness, interest, and learning profile in academically diverse classrooms: A review of literature. Journal for the Education of the Gifted, 27(2/3), 119-145.

VanTassel-Baska, J. (2006). A content analysis of evaluation finding across 20 gifted programs: A clarion call for enhanced gifted program development. Gifted Child Quarterly, 50(3), 199-215.

VanTassel-Baska, J., Feng, A. X., Brown, E., Bracken, B., Stambaugh, T., French, H., \& Bai, W. (2008). A study of differentiated instructional change over 3 years. Gifted Child Quarterly, 52(4), 297-312.

VanTassel-Baska, J., MacFarlane, B., \& Feng, A. X. (2006a). A cross-cultural study of exemplary teaching: What do Singapore and the United States secondary gifted class teachers say? Gifted and Talented International, 21(2), 38-47.

VanTassel-Baska, J., Quek, C., \& Feng, A. (2005). The classroom observation scale revised manual. Williamsburg, VA: The College of William and Mary.

VanTassel-Baska, J., Quek, C., \& Feng, A. X. (2006b). The development and use of a structured teacher observation scale to assess best practice. Roeper Review, 29(2), 84-92.

Vialle, W., \& Quigley, S. (2002). Selective students' view of the essential characteristics of effective teachers (Unpublished manuscript). University of Wollongong, Wollongong, NSW. 


\title{
Relationship between Encouraging Excellence in Pupils and Teachers' Attitudes towards Science: An Example from Croatia
}

\author{
Petra Pejić Papak \\ University of Rijeka, Croatia \\ petra.pejic.papak@uniri.hr \\ Jasna Arrigoni \\ University of Rijeka, Croatia \\ jarrigoni@uniri.hr \\ Željka Ivković \\ University of Rijeka, Croatia \\ zeljka.ivkovic@uniri.hr
}

Science is extremely important for the development of each country, but it is also important for the development of children, especially gifted ones. In this regard, teachers' attitudes towards science, the development of excellence and giftedness in children, play a significant role. Therefore, the purpose of this research was to determine the attitudes of teachers on science, their assessment of their importance for the development and advancement of society, and to which degree attitudes are related to the promotion of excellence among primary school pupils in three Croatian counties. The survey was conducted on a sample of 220 primary school teachers on a questionnaire constructed for this research. Factor analysis of teachers' attitudes towards science extracted four factors: Educational-developmental dimension of science, Science as a driver of social development, Positive feelings towards science, and Negative feelings towards science. Results indicate that these factors are statistically significantly related to the constructed index of school excellence, the length of teachers' work service and the size of the place of residence and place of growing-up. Teachers in the Primorje-Gorski Kotar County evaluated the educational practice of their school as more positive towards encouraging excellence than teachers in the other two counties, and teachers from the Lika-Senj County expressed more negative emotions towards dealing with science content in their work than their colleagues.

Keywords: attitudes towards science, excellence, giftedness, teachers' attitudes, Croatian educational system

\section{Introduction}

Science is extremely important for a country's development. In addition, it plays an important role in the development of children since it contributes 
to the development of logical and critical thinking (Pešikan \& Ivić, 2005). Especially emphasized is thereby the influence of science on the development of experimental thinking, i.e. the type of thinking that occurs when conducting experiments. This implies recognizing variables that have an effect on the occurrence.

However, research suggests that an increasing number of 15 -year-olds are losing interest in science. Reiss (2007) comments on the results of an international study called ROSE (Relevance of Science Education), ${ }^{1}$ a project coordinated by experts from the University of Oslo in Norway. The results of tens of thousands of children surveyed in more than 40 countries point to the relationship between a country's level of development and the interest in science. This has revealed that in more developed countries children are less interested in sciences at school. ${ }^{2}$

The Nuffield Foundation report (Osborne \& Dillon, 2008) concluded that education in the field of science has seven recommendations based on scientific research and indicators of significant organizations, as follows:

- The primary goal of science education in Europe should be to educate pupils in the direction of main explanations of the material world that science offers;

- Making innovations in the curriculum to motivate less interested pupils, especially girls;

- European countries need to invest more in resources to inform pupils how to develop their career in science;

- European countries should ensure the highest quality professional staff at the level of primary and secondary education, and that the emphasis on scientific education be in the period up to the 14th year of the child's life;

- Developing and expanding the way of teaching science is a key factor in encouraging pupils to engage more actively in learning about science;

- Invest more in research with a view to raising the level of knowledge, skills, and competences of pupils so as to become scientifically literate citizens of Europe;

\footnotetext{
${ }^{1}$ ROSE, The relevance of Science Education, is an international comparative study aimed at identifying significant factors in science and technology learning. 40 countries from around the world are included in this research. The Republic of Croatia did not participate in this study. For more see http://www.ils.uio.no/english/rose/about/rose-brief.html.

${ }^{2}$ Consequences of this are the closure of about 80 university physics departments in the UK in the last 6 years.
} 
- The priority of European politics must be to ensure a high level of professional teacher training (Osborne \& Dillon, 2008).

In the last decade, some progress has been made in the area of scientific research on science, natural sciences, importance of sciences for the development of society, but also of humanity as a whole. Thus, the possibilities of developing scientific abilities and creativity are considered as a prerequisite for high achievements and innovations in highly gifted individuals, and they conclude that the primary factors lie in the motivation and concept of selfperception (Heller, 2007). The possibilities of encouraging girls with greater involvement in mathematics and science are discussed with regards to the observed gender inequality in favour of boys (Kerr \& Robinson Kurpius, 2004; Freeman \& Garces-Bascal, 2015), as well as the relationship between potentially gifted pupils and their development within the framework of education for scientific contents (Taber, 2010; Taber \& Cole, 2010; Chowdhury, 2016), as well as ways to enrich the content of science education in schools in order for gifted pupils to meet their educational needs, curiosity, and interest in these areas (VanTassel-Baska, 1998; Taber, 2007; Australian Science Innovations, 2013).

Significant guidelines on the development of natural sciences rely on the results of PISA research, e.g. example between the years 2006 and 2015 in the context of international results. The result Croatia achieved in 2006 (493 points) suggests a statistically significantly lower average than the $O E C D$ project (500 points). According to the list of countries ranked by average results, it can be concluded that 'less than $20 \%$ of Croatian pupils are not able to use and apply acquired science skills in an adequate way' (Braš Roth, Gregurović, Markočić Dekanić, \& Makuš, 2008, p. 94). The latest results of the PISA test conducted in 2015 indicate a weaker result for Croatia in the area of science literacy. Every three years the average pupil's success in Croatia in this area drops by 5 points. ${ }^{3}$

Significantly better results for the Republic of Croatia have been achieved in the international research of trends in the knowledge of mathematics and sciences (Trends in International Mathematics and Science Study - TIMSS). ${ }^{4}$

${ }^{3}$ PISA - OECD's Programme for International Pupil Assessment - Program for international assessment of student literacy, mathematics and natural sciences. It is conducted by the International Consortium, led by the Australian Council for Research in Education. See www.pisa.oecd .org.

${ }^{4}$ For more about the results of the TIMSS research visit the website of the National Centre for External Evaluation, which is responsible for conducting research in Croatia (https://www.ncvvo .hr/poziv-objavu-rezultata-medunarodnog-istrazivanja-timss-2015/). 
Fourth and eighth grade pupils achieved a mathematics result at the level of TIMSS world average, and in science a statistically significantly higher score (533 points) than the survey average. More importantly, this result is higher than the result achieved in science for the year 2011. In this regard, the result of this test in 2015 is marked as a positive shift towards higher values, i.e. it speaks about better preparedness of our pupils in the fields of science and mathematics. The TIMSS research provides a set of research problems in such a way that, in addition to mathematics and natural sciences tasks, it also includes data obtained from the children, parents, and school workers on home learning conditions, school learning conditions (environment, curriculum, classroom climate etc.), and general socioeconomic indicators. One of the more interesting results is the fact that children of parents who have a very positive attitudes towards science and mathematics have statistically significantly higher achievements.

The above-mentioned international studies PISA and TIMSS also tackle answers to other issues, such as the factors of success in sciences related to pupils, the family, the school, the quality of teaching, and the like.

\section{Excellence in Education}

When it comes to excellence in education, different views on excellence are considered. The education system can foster excellence in each individual pupil, excellence of an educational institution or educational excellence in the most general sense at all levels of the system (Carey, Davis, Ferreras, \& Porter, 2015). In England, for example, as the main objective of the education system, emphasis is placed on achieving educational excellence in all schools throughout England, so that each child has a right to quality education. Therefore, the White Paper titled Educational Excellence Everywhere (Department for Education 2016) states that each child should have access to quality education regardless of his or her origin and residence, in order to maximize their potential and thus improve the quality of the society in which they live. Everything is based on the view that every child should be expected to reach maximum achievements regardless of their abilities, emphasizing thereby the greater importance of the school's professional autonomy and leadership. Achieving educational excellence is their most important achievement and hence their activities are steered in that direction. To achieve the expected educational excellence, they highlight seven key elements:

- Quality teachers, and in this regard addressing employment issues, rais- 
ing the quality of their education, accrediting new teachers, professional training and necessary materials, etc.

- Leadership of Educational Institutions is important as it provides support to existing leaders and organizes assistance in developing new high quality and excellence leaders in the future.

- Each school as an academy, with trained pupils, parents and community, and with a clearly defined role of the local government. Teachers can be most effective in excellent schools with excellent leaders.

- Preventing weaker school achievements and providing schools with support to develop from good to very successful.

- High expectations and leading curriculum for all advocates that every child deserves to complete their education with such knowledge and skills that will open up their opportunities for quality living. This will be achieved through quality curricula, changes in the evaluation of education, programs for the development of positive character traits in children and resistance to life problems they might face, meeting the needs of neglected groups of children: exceptionally capable, children with low achievement, children with developmental difficulties and reforming alternative forms of support so that regular schools are responsible for the advancement of children.

- Honest, responsible, flexible educational system for every child.

- Real resources in real hands: investing every single coin into the right place to achieve the best outcomes.

The known psychologist R. J. Sternberg (2008) raises the question of what excellence is, because the answer to that question depends on how we want to approach it. In his work Sternberg presents four models based on real school examples, which he himself had witnessed. The first model ${ }^{5}$ is the one in which schools are focused on looking 'down' towards children who are less successful or mostly unsuccessful by considering the ways in which they will reach minimum accomplishments based on the 'No Child Left Behind' document. By doing so, other groups of children were neglected, and among them were gifted pupils as it was considered that they will manage somehow on their own.

The second model ${ }^{6}$ is based on the looking 'up' view. The aforementioned

\footnotetext{
${ }^{5}$ For more on schools described by the author as examples for the first model, visit http: //shadysideschools.com/.

${ }^{6}$ As an example of this model, the author highlights the Sunnyvale School. For more information, visit https://www.sesd.org/Page/502.
} 
example of the school refers to the fact that the school cares only for that part of the pupil population that can be better and can do better, the socalled Matthew Effect - the intellectually rich are becoming richer, while the intellectually poor are becoming even poorer.

The third model ${ }^{7}$ is based on the non-existence of differences between classrooms or the kind of pupils who obediently do everything they are told (conformism). Being popular is good, but being intellectually excellent is very often suspicious. Such a model does not presuppose a program for gifted pupils, while a bare minimum of the program is put into practice for children with disabilities.

The fourth model ${ }^{8}$ outlines the examples of schools that require the achievement of above-average test scores and this is the main criterion for evaluating pupils. In this way those children who are on the top or bottom of the statistical scale, but also those in the middle, remain neglected. Raising test scores across schools in the United States is a national priority on which the ranking of educational institutions depends to a great extent. Therefore, Sternberg (2008) proposes a possible solution to the mentioned situations for the purpose of developing excellence in education. 'A better model for defining and achieving excellence is focusing on excellence in education for all pupils and allowing numbers to emerge as a result of seeking excellence rather than them being the main goal.' He suggests a model that relies on traditional reading, writing, computing, but now with an emphasis on the following three factors: reasoning, resilience, and responsibility that contribute to better quality development of the first three factors, and he also offers some tips on how to develop these three factors so as to develop excellence.

In the education system of Australia and in its state components, e.g. New South Wales (NSW Government, 2014a), the culture of excellence is encouraged in all schools by clearly describing key criteria that determine highquality educational practice through three areas: learning, teaching, and leadership. A framework was established for improving schoolwork (NSW Government, 2014b).

In order to achieve better results in scientific literacy, methodological approach and assessment of knowledge in science teaching should be directed to evaluations of the usability of the learned material, rather than relying

\footnotetext{
${ }^{7}$ As an example for the third model, the author mentions the Brookdale School. For more information, visit http://brookdale.ipsd.org/.

${ }^{8}$ As an example for the fourth model, the author mentions schools in the Riverside School District. For more information, visit http://www.riversidesd.org/schools.
} 
solely on the quantity of reproductive knowledge at a certain level of education (Braš Roth et al., 2008).

When stimulating scientific thinking, pupils should be helped to discover their own way, i.e. their own way of learning, to develop their metacognitive skills that will include planning, observation, evaluation, and learning content choices. Thus, Freeman (2003) mentions the problem of the teachers' frequent rigid steering of pupils in a certain direction, thus disrupting the autonomy and motivation of the pupil for achievement. Nisbet (1990, according to Freeman, 2003) suggests to teachers the following methods that can assist pupils in developing autonomy in learning:

- Talk out Loud - while exploring a problem, the teacher should speak loudly to understand and hear all pupils, and to adopt and understand the entire course of work.

- Cognitive Teaching - the teacher demonstrates the entire research process. Pupils have the opportunity to see the experiment 'first-hand,' on the right example.

- Discussion - is organized after the experiment has been performed. It carries out an analysis of the entire research process. Rich in arguments.

- Collaborative learning - pupils present their conclusions to each other. Cooperative 'teaching-learning' interactions are ideal for achieving higher levels of understanding.

- Socratic Examination - a teacher's cautious examining, which encourages pupils to express their thought processes and present their own arguments. The examination is not aimed at acquiring new skills; it instructs pupils to use the knowledge they already possess.

In order to contribute to the autonomy of a gifted pupil, Freeman (2003) recommends asking a simple question, 'What have you learned today?' which allows the pupil to recognize and reflect on the learned content. More systematic scientific research conducted worldwide in this area shows that there are different predictors that affect those attitudes. Some authors (Tirri, Tallent-Runnels, Adams, Yuen, \& Lau 2002) have found that in cross-cultural studies it is very important to determine the criteria according to which teachers' attitudes differ in different cultures. Studies also show that the experience of working with gifted pupils, the quality of this experience and the acquisition of professional competences from the field of gifted education, acquired during undergraduate studies or by means of a special training, significantly affect the development of more positive attitudes of teachers 
towards gifted pupils (Jung, 2014; Arrigoni, 2017). Research conducted in the Republic of Croatia (Krijan \& Borić, 2015) has shown that primary school teachers have positive attitudes towards the educational needs of gifted pupils, but they show ambivalent attitudes towards acceleration as one of the possible forms of support to the gifted in the educational system and towards grouping based on skills.

There are still many prejudices and stereotypes about the gifted (Baudson, 2016) and the growing number of scientific research is one way of contributing to solving the many dilemmas that come to mind to those who are teachers, but also to those who are not.

\section{Research Methodology}

\section{Research Aim}

The aim of this research was to examine teachers' views on science and to determine whether such attitudes are associated with promoting excellence in pupils.

\section{Research Tasks}

1. To analyse teachers' attitudes towards science.

2. To determine the correlation between the teachers' views on science with the created excellence index of schools and the length of teachers' work experience.

3. To examine the connection between the teachers' attitudes towards science with respect to the county in which they work and the size of the residential area in which the respondents have grown up and are currently living.

\section{Process of Data Collection}

The research was conducted in May of 2015 by means of a survey method conducted in the Republic of Croatia among primary school teachers in the Primorsko-goranska, Lika-Senj, and Istria counties. Data were collected by attending three Expert Councils of classroom teaching (one Expert Council per each county), organized by the Agency for Science and Higher Education, at which classroom teachers from various schools of the mentioned counties were present. Completing the survey was voluntary and anonymous. Teachers received the survey during the Expert Council, and it took approximately 20 minutes to complete it. A total of 230 surveys were distributed, and 220 fully completed surveys were returned and analysed. 
Table 1 Socio-Demographic Indicators of Respondents

\begin{tabular}{llrr}
\hline Indicator & Category & $f$ & $\%$ \\
\hline Gender & Male & 9 & 4.1 \\
& Female & 210 & 95.9 \\
& Total & 219 & 100.0 \\
\hline Degree of education & College degree & 71 & 32.4 \\
& University degree & 148 & 67.6 \\
& Total & 219 & 100.0 \\
\hline County & Primorje-Gorski Kotar & 80 & 36.4 \\
& Istria & 73 & 33.2 \\
& Lika-Senj & 67 & 30.5 \\
& Total & 220 & 100.0 \\
\hline Size of the place of residence & Up to 10 ooo inhabitants & 119 & 55.3 \\
where the respondent grew up & More than 10 ooo inhabitants & 96 & 44.7 \\
& Total & 215 & 100.0 \\
\hline Size of the place of residence & Up to 10 ooo inhabitants & 123 & 58.0 \\
where the respondent lives & More than 10 ooo inhabitants & 89 & 42.0 \\
& Total & 212 & 100.0 \\
\hline Age & $\bar{x}$ & 40.53 & \\
& Md & 40.00 & \\
& Mod & 50.00 & \\
\hline & Min-Max & $24-64$ & \\
\hline
\end{tabular}

\section{Respondents}

The total number of respondents (Table 1 ) included 220 teachers of classroom teaching. The majority of the respondents were female (95.5\%); the youngest respondent was 24 and the oldest 64 years of age, and the average age is 40.53 years. The majority of teachers have a college degree $(67.6 \%)$, while a lesser number has only a high school degree (32.4\%). At the level of surveyed counties, data were collected from an equal number of teachers: from Primorje-Gorski Kotar $36.4 \%$, Istarska $33.2 \%$, and Lika-Senj County $30.5 \%$ of teachers. There was a somewhat larger number of teachers who grew up in residential areas of up to 10,000 inhabitants $(55.3 \%)$ and who are living in an area of up to 10,000 inhabitants (58\%).

\section{Measuring Instruments}

For the purposes of research, a survey was used to examine the attitudes of science teachers using a five-degree assessment scale ( 1 - I fully disagree, 2 - I disagree, 3 - I neither agree nor disagree, 4 - I agree, I fully agree). The 
survey was made up of the following items: 'Education in the field of science is necessary for pupils to be more involved in the technological problems of society;' 'Content of science classes is essential for the pupils' development;, 'Science in primary school is necessary so that pupils would be able to make the right choices in their education;' 'Science must be represented in primary education as early as possible;' 'Teachers with less experience working on scientific topics should also be additionally trained in this area;' 'Science is the foundation of social development;' 'Building a society rests on studies in science;' 'If a child loves to learn, (s)he should be directed to science;' 'Knowing the methods of scientific work is the deciding factor in the decision whether to teach natural science in the classroom or not;; 'Availability of resources and aids determines my decision to teach science content;' 'I am very capable of dealing with pupils' science questions;' 'I have enough knowledge of the content to be able to provide quality support to pupils in research and project design;' 'If pupils do not come up with solutions when working on science projects, I believe I can successfully assist them in finishing the task;' 'In terms of the content, I consider science a difficult subject to teach; In terms of spatial and material condition, I consider teaching science content as challenging;' 'I feel insufficiently competent to teach natural sciences in the classroom.'

A school excellence index was also created with Cronbach alpha 0.739 on the following particles: 'Teachers who inspire new ideas methods of education and approaches are supported; The content of teaching is adjusted to the pupils' interests in different areas of action; School equipment enables the use of different knowledge sources; Excellence is encouraged in each pupil; Emphasis is placed on steering the pupils towards science.' The responses were measured on a five-point assessment scale (ranging from 1 not applicable to my school to 5 - fully applicable to my school).

Apart from the aforementioned, the following socio-demographic indicators were analysed: gender (dichotomous variable), age (open question), degree of education (two categories: college and university), counties where the respondents work (Primorje-Gorski Kotar, Istria, and Lika-Senjska counties) the size of the residence area where the respondent grew up and is currently living (two categories: up to and more than 10,000 inhabitants).

\section{Statistical Analysis}

Data were processed using the IBM SPSS Version21. Descriptive statistics determined the basic response distribution of teachers' attitudes towards science, and a factor analysis of attitudes was conducted. The $t$-test for in- 
dependent samples was used to compare the teachers' attitudes towards science and the excellence index with regards to the size of the residence area where they grew up and are living now. ANOVA was used to determine the differences in socio-demographic indicators of the county with regards to the mentioned teachers' attitudes towards science and the excellence index.

\section{Results}

Using descriptive statistics of the teachers' attitudes towards science, factor modelling and the varimax rotation analysis were conducted whereby four factors were extracted in addition to the GK criterion, which explains $59.82 \%$ of the common variance. Cronbach alpha is 0.833 .

In the structuring of the first factor (Table 2) five variables explain $16.94 \%$ of the variance. The first factor is saturated with the following variables: $E d-$ ucation in the field of science is necessary for pupils to be more involved in the technological problems of society; Content of science classes is essential for the pupils' development; Science in primary school is necessary so that pupils would be able to make the right choices in their education; Science must be represented in primary education as early as possible; and Teachers with less experience working on scientific topics should also be additionally trained in this area.

With regards to the variables that point to the importance of education in the field of science, the necessity and representation of the content of science in primary school education and the importance of experience and necessity of further teacher training in this field, we can call the aforementioned factor Educational-developmental dimension of science.

Five variables are involved in the structuring of the second factor, which explains $16.44 \%$ of the variance. The second factor is saturated with the following variables: Science is the foundation of social development; Building a society rests on scientific studies and If a child loves to learn, (s)he should be directed to science; Knowing the methods of scientific work is the deciding factor in the decision whether to teach natural science in the classroom or not and Availability of resources and aids determines my decision to teach science content. The second factor, given the variables that point to the importance of teaching natural sciences as the foundation of social development, can be called Science as a driver of social development. It contains elements of an educational process aimed at teaching natural science contents by knowing the work methods and the availability of resources and aids that are also conditioned by the teachers' decisions on content teaching.

In the structuring of the third factor, three variables explain $14.16 \%$ of the 
Table 2 Factor Analysis of Teachers' Views towards Natural Sciences

\begin{tabular}{|c|c|c|c|c|}
\hline Items & F1 & $\mathrm{F}_{2}$ & $\mathrm{~F}_{3}$ & $\mathrm{~F} 4$ \\
\hline $\begin{array}{l}\text { Education in the field of science is necessary for pupils to be } \\
\text { more involved in the technological problems of society. }\end{array}$ & 0.803 & & & \\
\hline $\begin{array}{l}\text { Content of science classes is essential for the pupils' develop- } \\
\text { ment. }\end{array}$ & 0.741 & & & \\
\hline $\begin{array}{l}\text { Science in primary school is necessary so that pupils would be } \\
\text { able to make the right choices in their education. }\end{array}$ & 0.691 & & & \\
\hline $\begin{array}{l}\text { Science must be represented in primary education as early as } \\
\text { possible. }\end{array}$ & 0.686 & & & \\
\hline $\begin{array}{l}\text { Teachers with less experience working on scientific topics } \\
\text { should also be additionally trained in this area. }\end{array}$ & 0.525 & & & \\
\hline Science is the foundation of social development. & & 0.807 & & \\
\hline Building a society rests on scientific studies. & & 0.747 & & \\
\hline If a child loves to learn, (s)he should be directed to science. & & 0.717 & & \\
\hline $\begin{array}{l}\text { Knowing the methods of scientific work is the deciding factor } \\
\text { in the decision whether to teach natural science in the class- } \\
\text { room or not. }\end{array}$ & & 0.560 & & \\
\hline $\begin{array}{l}\text { Availability of resources and aids determines my decision to } \\
\text { teach science content. }\end{array}$ & & 0.521 & & \\
\hline I am very capable of dealing with pupils' science questions. & & & 0.828 & \\
\hline $\begin{array}{l}\text { I possess enough knowledge of the content to be able to pro- } \\
\text { vide quality support to pupils in research and project design. }\end{array}$ & & & 0.790 & \\
\hline $\begin{array}{l}\text { If pupils do not come up with solutions when working on sci- } \\
\text { ence projects, I believe I can successfully assist them in finish- } \\
\text { ing the task. }\end{array}$ & & & 0.725 & \\
\hline $\begin{array}{l}\text { In terms of the content, I consider science a difficult subject to } \\
\text { teach. }\end{array}$ & & & & 0.776 \\
\hline $\begin{array}{l}\text { In terms of spatial and material condition, I consider teaching } \\
\text { science content as challenging. }\end{array}$ & & & & 0.772 \\
\hline $\begin{array}{l}\text { I feel insufficiently competent to teach natural sciences in the } \\
\text { classroom. }\end{array}$ & & & & 0.563 \\
\hline
\end{tabular}

Notes $F_{1}$-Educational-developmental dimension of science, $F_{2}$ - Science as a driver of social development, $\mathrm{F}_{3}$ - Positive feelings towards science, $\mathrm{F}_{4}$ - Negative feelings towards science.

variance, namely: I am very capable of dealing with pupils' science questions; I possess enough knowledge of the content to be able to provide quality support to pupils in research and project design; and If pupils do not come up with solutions when working on science projects; and I believe I can successfully assist them in finishing the task. With regards to the orientation of the variables on teachers' competences of those teachers who demonstrate possession of sufficient knowledge about the science content and the ability to teach and 
Table 3 Bivariate Correlation between the Factor of Teachers' Attitudes towards Science with the Excellence Index and the Length of Work Experience

\begin{tabular}{|c|c|c|c|c|c|c|}
\hline & \multicolumn{3}{|c|}{ Excellence index } & \multicolumn{3}{|c|}{ Length of work exp. } \\
\hline & $N$ & $r$ & $p$ & $N$ & $r$ & $p$ \\
\hline $\begin{array}{l}\text { Educational-development dimension } \\
\text { of science }\end{array}$ & 205 & 0.185 & $0.008^{* *}$ & 192 & 0.075 & 0.299 \\
\hline $\begin{array}{l}\text { Natural science as a driver of social } \\
\text { development }\end{array}$ & 205 & 0.115 & 0.100 & 192 & 0.011 & 0.881 \\
\hline Positive feelings towards science & 205 & 0.137 & $0.049^{*}$ & 192 & 0.258 & $0.001^{* *}$ \\
\hline Negative feelings towards science & 205 & -0.144 & $0.039^{*}$ & 192 & -0.072 & 0.323 \\
\hline
\end{tabular}

Notes ${ }^{*} p<0.05,{ }^{* *} p<0.01$.

provide support to pupils, the third factor can be called Positive feelings towards science.

Three variables were used in the structuring of the fourth factor, which explains $12.28 \%$ of the variance. The fourth factor has saturations on the following variables: In terms of the content, I consider science a difficult subject to teach; In terms of spatial and material condition, I consider teaching science content as challenging; and I feel insufficiently competent to teach natural sciences in the classroom. The fourth factor, given the variables that point to attitudes towards science as being a difficult and challenging subject, and the lacking competence to teach it, can be called Negative feelings towards science.

\section{Connectedness between the Factor of Teachers' Attitude towards Natural Sciences and the Excellence Index and the Length of work Experience}

It is evident (Table 3) that the higher the teachers' assess the excellence of their school, the more expressive they are about their personal tendency towards the Educational-developmental dimension of science $(r=185)$ and Positive feelings towards science $(r=137)$, while the opposite results in Negative feelings toward science $(r=-0.144)$. The length of work experience is positively correlated with the factor Positive feelings towards science $(r=0.258)$.

Developing positive attitudes towards science depends first and foremost on the way in which schools teach it (Coates, 2009). Research conducted in the Republic of Croatia (Rukavina, Žuvić-Butorac, Ledić, Milotić, \& JurdanaSepic, 2012) speaks in favour of the view that a change in the strategy when teaching mathematics and science develops more positive attitudes among the pupils towards them. It is equally important that developing positive attitudes towards science should begin as early as possible (Robinson, Dailey, Hughes, \& Cotabish, 2014), with better professional development of teachers and a curriculum enriched with problem-research tasks. 
Table 4 ANOVA Differences in the Excellence Index and the Acceptance of the Factor of Teachers' Attitudes towards Science with Regards to the County

\begin{tabular}{|c|c|c|c|c|c|c|c|c|c|}
\hline & & \multirow[t]{2}{*}{$N$} & \multirow[t]{2}{*}{$\bar{x}$} & \multirow[t]{2}{*}{$F$} & \multirow[t]{2}{*}{$p$} & \multicolumn{4}{|c|}{ Multiple comparison test } \\
\hline & & & & & & I & $J$ & $I-J$ & $p$ \\
\hline \multirow{9}{*}{$\begin{array}{l}\text { Excellence } \\
\text { index* }\end{array}$} & PGC & 80 & 4.01 & 13.366 & 0.001 & PGC & IŽ & 0.504 & 0.000 \\
\hline & & & & & & & LSŽ & 0.323 & 0.003 \\
\hline & IC & 73 & 3.50 & & & IC & PGC & - & 0.000 \\
\hline & & & & & & & & 0.504 & \\
\hline & & & & & & & LSŽ & - & 0.292 \\
\hline & & & & & & & & 0.180 & \\
\hline & LSC & 67 & 3.68 & & & LSC & PGC & - & 0.003 \\
\hline & & & & & & & & 0.323 & \\
\hline & & & & & & & IŽ & 0.180 & 0.292 \\
\hline \multirow{10}{*}{$\begin{array}{l}\text { Negative } \\
\text { feelings } \\
\text { towards } \\
\text { science** }^{* *}\end{array}$} & PGC & 72 & - & 5.667 & 0.004 & PGC & IŽ & 0.033 & 1.000 \\
\hline & & & 0.132 & & & & & & \\
\hline & & & & & & & LSŽ & - & 0.014 \\
\hline & & & & & & & & 0.485 & \\
\hline & IC & 72 & - & & & IC & PGC & - & 1.000 \\
\hline & & & 0.166 & & & & & 0.033 & \\
\hline & & & & & & & LSŽ & - & 0.008 \\
\hline & & & & & & & & 0.518 & \\
\hline & LSC & 61 & 0.352 & & & LSC & PGŽ & 0.485 & 0.014 \\
\hline & & & & & & & IŽ & 0.518 & 0.008 \\
\hline
\end{tabular}

Notes * Tamhane T2 was used with the Excellence index. ${ }^{* *}$ Bonferroni test was used with Negative feelings towards science.

\section{Differences in the Excellence Index and the Factor of Accepting Teachers'} Attitudes towards Science between Counties and in the Size of Residential Areas in Which the Respondents Grew up and Are Living Now

Results of ANOVA (Table 4) show that there are statistically significant differences in attitudes related to the excellence index $(F=13.366, p=0.000)$ among counties, i.e. teachers from the Primorje-Gorski Kotar County $(\bar{x}=4.01)$ have a statistically significantly higher average of attitudes towards the excellence index than teachers from the Lika-Senj County $(\bar{x}=3.68)$ and Istria County $(\bar{x}=3.50)$.

At the same time there are statistically significant differences among counties with regards to the teachers' attitudes towards the factor of Negative feelings towards science ( $F=5.667, p=0.004$ ), i.e. teachers from the LikaSenj County $(\bar{x}=352)$ accept Negative feelings towards science to a greater degree than teachers from the Primorje-Gorski Kotar County $(\bar{x}=-0.132)$ and the Istria County $(\bar{x}=-0.166)$. 
Table $5 t$-Test for Independent Samples: Differences in the Index of Excellence and the Factor of Acceptance of Teachers' Attitudes towards Natural Sciences with Regards to the Size of the Residential Area Where the Respondents Grew up and Are Living Now

\begin{tabular}{|c|c|c|c|c|c|c|c|c|}
\hline & & & $N$ & $\bar{x}$ & $s$ & $t$ & $d f$ & $p$ \\
\hline \multirow{10}{*}{$\begin{array}{l}\text { Grew } \\
\text { up }\end{array}$} & \multirow{2}{*}{$\begin{array}{l}\text { Educational-development } \\
\text { dimension of science }\end{array}$} & (1) & 119 & -0.127 & 1.001 & -1.670 & 198 & 0.097 \\
\hline & & (2) & 96 & 0.103 & 0.938 & -1.680 & 195 & 0.095 \\
\hline & \multirow{2}{*}{$\begin{array}{l}\text { Science as a driver of social } \\
\text { development }\end{array}$} & (1) & 119 & 0.092 & 0.885 & 1.129 & 198 & 0.260 \\
\hline & & (2) & 96 & -0.067 & 1.114 & 1.106 & 170 & 0.270 \\
\hline & \multirow{2}{*}{$\begin{array}{l}\text { Positive feelings towards } \\
\text { science }\end{array}$} & (1) & 119 & 0.074 & 1.048 & 0.998 & 198 & 0.319 \\
\hline & & $(2)$ & 96 & -0.067 & 0.944 & 1.007 & 196 & 0.315 \\
\hline & \multirow{2}{*}{$\begin{array}{l}\text { Negative feelings towards } \\
\text { science }\end{array}$} & (1) & 119 & 0.250 & 0.949 & 3.930 & 198 & 0.001 \\
\hline & & (2) & 96 & -0.286 & 0.978 & 3.920 & 189 & 0.000 \\
\hline & \multirow[t]{2}{*}{ Excellence index } & (1) & 119 & 3.689 & 0.622 & -1.062 & 213 & 0.289 \\
\hline & & (2) & 96 & 3.781 & 0.652 & -1.057 & 199 & 0.292 \\
\hline \multirow[t]{10}{*}{ Living } & \multirow{2}{*}{$\begin{array}{l}\text { Educational-development } \\
\text { dimension of science }\end{array}$} & (1) & 114 & -0.177 & 0.952 & -2.539 & 196 & 0.012 \\
\hline & & (2) & 84 & 0.173 & 0.977 & -2.529 & 176 & 0.012 \\
\hline & \multirow{2}{*}{$\begin{array}{l}\text { Science as a driver of social } \\
\text { development }\end{array}$} & (1) & 114 & 0.057 & 0.824 & 0.872 & 196 & 0.384 \\
\hline & & $(2)$ & 84 & -0.066 & 1.180 & 0.827 & 140 & 0.409 \\
\hline & \multirow{2}{*}{$\begin{array}{l}\text { Positive feelings towards } \\
\text { science }\end{array}$} & (1) & 114 & 0.004 & 1.104 & 0.055 & 196 & 0.956 \\
\hline & & $(2)$ & 84 & -0.003 & 0.852 & 0.057 & 195 & 0.955 \\
\hline & \multirow{2}{*}{$\begin{array}{l}\text { Negative feelings towards } \\
\text { science }\end{array}$} & (1) & 114 & 0.118 & 0.873 & 1.815 & 196 & 0.071 \\
\hline & & (2) & 84 & -0.140 & 1.136 & 1.745 & 150 & 0.083 \\
\hline & \multirow[t]{2}{*}{ Excellence index } & (1) & 123 & 3.672 & 0.638 & -1.569 & 210 & 0.118 \\
\hline & & (2) & 89 & 3.811 & 0.636 & -1.570 & 190 & 0.118 \\
\hline
\end{tabular}

Notes (1) Up to 10,000 inhabitants. (2) More than 10,000 inhabitants. ${ }^{*} p<0.01,{ }^{* *} p<0.05$.

No statistically significant differences were found between the counties on other factors: Educational-development dimension of science, Science as a driver of social development, Positive feelings towards science.

\section{Connectedness between the Teachers' Attitudes towards Science with Regards to the Size of the Residential Areas in Which They Grew up and Are Living Now}

The $t$-test indicators (Table 5) point to statistically significant differences between the attitudes of those teachers who grew up in smaller areas (up to 10,000 inhabitants); they are more likely to accept the factor Negative feelings towards science ( $t=3.930, p=0.000$ ) than teachers from larger residential areas (more than 10,000 inhabitants).

A statistically significant difference is observable in teachers' attitudes to- 
wards the factor Educational-development dimension of science with regards to the size of the residential area in which the respondents are living.

Teachers living in larger areas (more than 10,000 inhabitants) are more accepting of the Educational-development dimension of science than teachers living in smaller areas (up to 10,000 inhabitants) $(t=-2.539, p=0.012)$.

\section{Conclusion}

Science content is often abstract, invisible to the naked eye, and not sufficiently related to children's experience, which leads children to develop a negative attitude towards the content they do not understand and have difficulty adopting. Therefore, materials prepared for preschool children (e.g. Rothschild, Daniels, 1999) are much needed so as to guide the development of the first attitudes towards nature and the laws of nature through very simple activities and experiments. Some sources point to the combination of scientific research and their results and existing practice, highlighting thereby how to use research results so as to improve the immediate educational practice in the work with gifted and talented pupils in science. Teachers' attitudes towards gifted pupils and the possible forms of their education are crucial in organizing systematic care for the gifted, because they are the first direct creators of pedagogical situations, and their acceptance of the attitude of gifted education depends on the further implementation of the program.

Factor analysis of teachers' attitudes towards science, survey method conducted in the Republic of Croatia among primary school teachers, extracted four factors: Educational-developmental dimension of science, Science as a driver of social development, Positive feelings towards science and Negative feelings towards science. Results indicated that these factors are statistically significantly related to the constructed index of school excellence, the length service of teachers, and the size of the place of residence and place of growing-up.

Teachers in Primorje-Gorski Kotar County evaluated the educational practice of their school as more positive towards encouraging excellence than teachers in the other two counties, and teachers from Lika-Senj County expressed more negative emotions towards dealing with science content in their work than their colleagues. Teachers from larger places of residence (more than 10.000 inhabitants) accepted the factor Educational-developmental dimension of science more than teachers from smaller places of residence (up to 10.000 inhabitants). Teachers who grew up in smaller areas accepted the factor Negative feelings towards science more than teachers who grew up in larger areas. 
The Nuffield Foundation report (Osborne \& Dillon, 2008) concluded that education in the field of science in Europe has found itself in significant problems. Especially in the fields of curriculum, teaching, evaluation and professional development of teachers, as this requires changing the purpose of science education. They point out that it should be directed to the entire population of children, not just to those who, due to their expressed abilities and interests, prefer those areas.

\section{Acknowledgements}

This paper was funded by the University of Rijeka within research project 'Culture of Educational Institution as a Factor in Co-construction of Knowledge' (No. 13.10.2.2.01).

\section{References}

Arrigoni, J. (2017). Pedagoško strukturiranje kurikuluma za darovite učenike [Pedagogical structuring of curriculum for gifted students] (Unpublished doctoral dissertation). University of Zagreb, Croatia.

Australian Science Innovations. (2013). Developing programs in science for gifted and talented students. Retrieved from https://www.asi.edu.au/wp-content /uploads/2015/03/Developing-programs-in-science-for-gifted-and -talented-students_pdfv2.pdf

Baudson, T. G. (2016). The mad genius stereotype: Still alive and well. Frontiers in Psychology, 7, 368. Retrieved from https://dx.doi.org/10.3389\%2Ffpsyg .2016 .00368

Braš Roth, M., Gregurović, M., Markočić Dekanić, A., Makuš, M. (2008). PISA 2006: prirodoslovne kompetencije za život [PISA 2006: Natural science competences for life]. Zagreb, Croatia: Nacionalni centar za vanjsko vrednovanje obrazovanja - PISA centar.

Carey, T., Davis, A., Ferreras, S., Porter, D. (2015). Using open educational practices to support institutional strategic excellence in teaching, learning \& scholarship. Open Praxis, 7(2), 161-171.

Chowdhury, M. A. (2016). Gifted education in science and chemistry: Perspectives and insights into teaching, pedagogies, assessments, and psychosocial skills development. Journal for the Education of Gifted Young Scientists, $4(1), 53-66$.

Coates, D. (2009). Developing challenging science activities for gifted pupils through action research. Education 3-13, 37(3), 259-268.

Department for Education (2016). Educational Excellence Everywhere. Retrived from https://assets.publishing.service.gov.uk/government/uploads/ system/uploads/attachment_data/file/508447/Educational_Excellence _Everywhere.pdf 
Freeman, J. (2003). Scientific thinking in gifted children. In P. Csermely \& L. Lederman. (Eds.) Science education: Talent recruitment and public understanding (pp. 17-30). Amsterdam, The Netherlands: IOS Press.

Freeman, J., \& Garces-Bascal, R. M. (2015). Gender differences in gifted children. In M. Neihart, S. I. Pfeiffer, \& T. L. Cross (Eds.), The social and emotional development of gifted children: What do we know? Waco, TX: Prufrock.

Heller, K. A. (2007). Scientific ability and creativity. High Ability Studies, 18(2), 209-234.

Jung, J. Y. (2014). Predictors of attitudes to gifted programs/provisions: Evidence from preservice educators. Gifted Child Quarterly, 58(4), 247-258.

Kerr, B., \& Robinson Kurpius, S. E. (2004) Encouraging talented girls in math and science: Effects of a guidance intervention. High Ability Studies, 15(1), 85102.

Krijan, I., \& Borić, E. (2015). Primary school teachers' attitudes toward gifted students. Croatian Journal of Education, 17(3), 681-724.

Nisbet, J. (1990). Teaching thinking: An introduction to the research literature (Spotlights 26). Edinburgh, Scotland: SCRE.

NSW Government. (2014a). School Excellence Framework. Retrieved from https:// schoolsequella.det.nsw.edu.au/file/b214ao8b-5c9d-4ca2-9eb7

-caaf7e6e53ao/1/School_Excellence_Framework.pdf

NSW Government. (2014b). School improvement frameworks: The evidence base. Retrieved from https://www.cese.nsw.gov.au/images/stories/PDF/School _improvement_frameworks-The_evidence_base.pdf

Osborne, J., \& Dillon, J. (2008). Science education in Europe: Critical reflections (Report to the Nuffield Foundation). Retrieved from http://www .nuffieldfoundation.org/sites/default/files/Sci_Ed_in_Europe_Report _Final.pdf

Pešikan, A., \& Ivić, I. (2005). Prirodne nauke i aktivno učenje [Natural sciences and active learning]. In S. Antić, M. R. Jankov, \& A. Pešikan (Eds.), Kako približiti deci prirodne nauke kroz aktivno učenje (pp. 7-14). Beograd, Serbia: Institut za psihologiju.

Reiss, M. (2007). Komentar: Temelj nastave prirodoslovlja. [Commentary: The foundation of natural science teaching]. Retrieved from http://www .eskola.hfd.hr/proe_za_vas/proc-22/proc22.htm.

Robinson, A., Dailey, D., Hughes, G., and Cotabish, A. (2014). The effects of a science-focused STEM intervention on gifted elementary students' science knowledge and skills. Journal of Advanced Academics, 25(3), 189-213.

Rukavina, S., Žuvić-Butorac, M., Ledić, J., Milotić, B., \& Jurdana-Šepić, R. (2012). Developing positive attitude towards science and mathematics through motivational clasroom experiences. Science Education International, 23(1), 6-19.

Sternberg, R. J. (2008). Excellence for all. Expecting Excellence, 66(2), 14-19. 
Taber, K. S. (2007). Enriching school science for the gifted learner. Cambridge, England: Gatsby Technical Education Projects.

Taber, K. S., \& Cole, J. (2010). The CREST awards scheme: Challenging gifted and talented students through creative STEM project work. School Science Review, 92(339), 117-126.

Tirri, A. K., Tallent-Runnels, M. K., Adams, A. M., Yuen, M., \& Lau, P. S. Y. (2002, April). Cross-cultural predictors of teachers' attitudes toward gifted education: Finland, Hong Kong and USA. Paper presented at the Annual meeting of the American Educational Research Association, New Orleans, LA.

VanTassel-Baska, J. (1998). Planning science programs for high-ability learners. Retrieved from http://www.davidsongifted.org/Search-Database/entry /A10273 



\title{
Didactic Strategies in the Function of Developing Intellectual Talents of Gifted Students
}

\author{
Aleksandar Stojanović \\ University of Belgrade, Serbia \\ aleksandar.stojanovic@uf.bg.ac.rs
}

\begin{abstract}
The theme data are analysed from different perspectives based on the findings of wider exploratory research in which the influence of didactic strategies on the development of intellectual abilities of gifted students was studied. The article tested hypothesis related to the importance of certain didactic strategies for the development of metacognitive and creative competences of students. The sample was made up of 112 students of master pedagogy studies in Serbia whose average in studies is over 9.00. Students have shown greater need for the following methods: research method, interpretation, evaluation, academic presentation, practical work, creating new ideas, finding new procedures, self-reflexive learning, storming ideas, comparisons, interactive learning, self-organized learning, learning by discovery, problem learning, comparing data, problem statement, formulation of concepts, summarizing ideas, ask questions, find examples on the Internet and in literature, writings, references to interesting details, explanation of positions, the debate on the subject, thinking confrontation, talking about the pre-set problems. The possibilities of innovating teaching and learning strategies at the higher education level were analysed especially by examining the application of the method of discourse that seeks to contribute the goals of emancipatory didactics.
\end{abstract}

Keywords: gifted students, didactic strategies, intellectual abilities

\section{Introduction}

So far, the results of the reforms in higher education and the intentions of the Bologna Process are not as visible in the development of students' competences as in structural changes, which are oriented towards the coherence of the European Higher Education Area. Substantial changes in higher education that directly contribute to the quality of studies are not yet sufficiently manifest, although they were expected to make a significant contribution to the achievement of creative and undogmatic thinking among students, including gifted, their abilities to accept plurality of ideas, tolerance of uncertainty in cognitive sense, and in conceptual initiative, innovation and readiness to take risks (Đurišić-Bojanović, 2008, p. 45). In practice, with the advancement of reforms it becomes more and more clear that the reform 
essentially involves the structural and organizational side, with the consequences that, from the perspective of higher education didactics, reforms are opposed to the development of the quality of science and studies. The foreseen task of higher education institutions is to develop more innovation strategies related to the organization of learning contents, teaching materials and teaching methods (Eberhardt, 2010).

There is a need for new didactic impulses to mitigate criticism, such as the very negative estimates of Conrad Paul Lisman in his Theory of Noneducation (Lissmann, 2006). Similarly, assessments of the achievement of reform intentions in Serbia relate to the reduction of the level of requirements in academic studies, the limitation of professors and students by the scope of studies, by the number of ECTS, the narrowing of areas into modules, semesters, etc., emphasizes the negative side of functional knowledge, technocratic approach to knowledge. Expert assessments emphasize the necessity of developing quality of higher education didactics and studying issues.

Higher education didactics emphasize stronger focus on learning and teaching in function of self-organized learning of students, self-responsive and self-determined characteristics which would enable gifted students to fully develop skills in line with current social trends. It would be necessary to integrate the aspects of emancipatory didactics into the formulation of study directions, with particular attention to the fact that the content of university studies is generated from the research. Therefore there is a need of didactic transformation by the teaching scientist himself, in order to establish the emancipatory 'culture of learning and teaching.'

Higher education didactics continue to examine their concepts, and within them, teaching methods, because they are directly related to the quality of studies. Within this, a significant place belongs to intellectual abilities, creativity and metacognition as indicators of the level of quality of higher education. Higher education didactics is expected to focus more intensively on emancipatory approaches of learning in terms of creating a 'quality of knowledge,' with the 'quality' concept that must be contextualized. The autonomy of learning and development can not be standardized,

\section{Contextual Approach to the Intellectual Abilities of Gifted and Didactic Strategies}

In the last decades, the cognitive system and its development are viewed as a self-modifying system, and learning is most often viewed from the same perspective as self-regulated learning. This perspectives in pedagogical psychol- 
ogy encouraged didactics to seek for mechanisms in which capabilities could be better understood and developed into cognition, by accepting the contextual approach to intellectual abilities (Sternberg, 1988). Research findings stating that specialized knowledge of students, and use of cognitive strategies and self-regulation have a significant impact on academic learning (Gojkov, Gojkov-Rajić, \& Stojanović, 2014; Sternberg, 1988).

According to many authors conclusions (Heller, 2000, as cited in Gojkov et al., 2014), gifted individuals can differ from average individuals, because they use essential information to solve problems, their comparing processes are faster, due to their competence in processing information, and focus on problem coding and more carefully problem analyze. The gifted use more and better strategies for solving problems from various fields, they quickly replace less appropriate strategies with more favourable strategies, and their cognitive monitoring is better (Robinson, 1993; Shore \& Kanevsky, 1993; Waldmann \& Weinert, 1990; all as cited in Gojkov et al., 2014; Sternberg, 1988).

The link between ability and realized (executive) intelligence is considered by metacognition (Flavel \& Felman, as cited in Gojkov et. al., 2014). This ability contributes the respect of conceptual mechanisms taking into consideration self-organization learning and interdependence. Therefore, the significance of metacognition is viewed through its impact on the operability and mobility of possessed knowledge, and this qualifies as an element that enables more effective self-regulation of learning, which today is considered to be significant cognitive competence. The term metacognition or metamemory refers to knowledge of the capacity/efficiency and function of the memory of a person or the whole cognitive.

Metacognition implies cognitive processes that choose adequate cognitive strategies, which execute and control them in relation to their effectiveness (Sternberg, 1988). All this helps to realize the ability, or to turn them into executive or realized intelligence. It is important to point out that the metacognitive processes are in the direct function of exercising capabilities and as such have an important role in recent theories of intelligence and giftedness (Sternberg, 1988). Research confirms the reciprocal of intellectual and metacognitive abilities and problem solving, leading to the conclusion that success in solving the problem is accompanied by high abilities (Stojanović \& Gojkov, 2016).

The theoretical basis of the research, which is further presented, is the emancipatory didactics, which is considered open due to changing perspectives - from teachers to students and competences to be acquired (Zervakis \& Wahler, 2007, as cited in Kruse, 2011). This change of perspective presupposes 
lectures directed to the student with more accurately observing their learning perspective and specifies 'output' as well as term 'competence' with aims to encourage, not only knowledge, but also complex abilities. According to O. Kruse (2011) as well as to Humboldt's tradition, teaching was oriented towards competences much more than today's framework of Bologna reform, the study was a field of intellectual and methodological abilities training and education. Only the notion of 'competence', according to mentioned authors, is new and triggers a more intensive didacticization of academic learning (Stojanović \& Gojkov, 2016).

Critical thinking, as one of the most important intellectual abilities, relies on emancipatory epistemology in the higher education didactic concept of gifted education. It is essentially the same in the emancipatory didactic, relying on the views of the authors, such as Paul and Elder (2003, as cited in Kruse, 2011) who consider that critical thinking refers to the aspects of selfmanagement and self reflection of thinking, depending on the monitoring of intellectual norms.

Modern didactics emphasize that students, and especially gifted, need didactic support that fosters the stimulation of intellectual autonomy. During the didactic development, many methods of developing intellectual autonomy have been created, and they still exist in Bologna Process conditions. However, there is no automatism by which the didactical possibilities would indeed cause the development of thinking skills, including critical thinking, as their effect depends on the curricular circumstances, as well as on the assumptions and motivations of students. Peer interaction can become a useless ritual if it does not focus on creative and fair communication between students, including gifted ones. Therefore, it is necessary to pay attention to thinking of the participants of the discussion and to create such an atmosphere, in which without risk you can experiment with forms of thinking. Brookfield (as cited in Kruse, 2011) indicates that in student group discussions it is important to check existing assumptions and statements and to explore alternative thinking options, to allow diversity and dissimilar opinions, to support spontaneity and risk readiness, to provide models for openness in thinking and for critical analysis, to establish basic scepticism and to avoid perfectionism.

Therefore, there are already well-known teaching strategies (known as Brookfield's List, see Gojkov, 2013), which indicate that teaching, edited by critical thinking, requires high communicative qualities of teachers and depends on creating an appropriate relationship between teacher and students. Students have to be supported and motivated to take a risky decision 
to open their own critical thinking according to pedagogic approach. Attempts to empirically validate some aspects of the previous didactic strategies views, in the function of developing the intellectual abilities of gifted students, were carried out in research that is briefly presented.

\section{Research Methodological Framework}

In one of our surveys (Gojkov, Stojanović, \& Gojkov-Rajić, 2015) relevant to the subject, the hypothesis about the significance of certain didactic strategies for the development of metacognitive and creative competences, i.e. the encouragement of the intellectual autonomy of gifted students learning, were checked. The hotimical sample was made by 112 students of master studies at the Faculty of Philosophy in Serbia - Department of Pedagogy, whose average in studies is over 9.00 , which they achieved in academic giftedness.

The method of systematic non-experimental observation and assessment scale was used. Students assessed the degree of presence of these strategies, methods or procedures during the studies courses, and how much the learning and teaching strategies used during classes, exercises, seminar exercises, as well as contribution to the development of competences. Students were given the choice of didactic strategies, methods and procedures. Among 52 methods, 30 are found related to problem learning, creative approaches to learning, critical autonomy, and so on. On the other hand, on the list of 35 competences, 30 are found related to self-thinking and represent elements of critical thinking. Findings present and indicate realization of intellectual autonomy of gifted students (DSKDS-1 - Didactic Strategies and Competences of Gifted Students). The Cronbach Alpha coefficient was 0.975, indicating a high reliability of the instrument.

The accessibility of didactic strategies and methods in higher education (lectures, exercises, seminars, consultations ...) to gifted students will be distinguished in the presentation of the findings. Gifted students have shown greater need for the following methods: research method, interpretation, evaluation, academic presentation, practical work, creating new ideas, finding new procedures, self-reflexive learning, storming ideas, comparisons, interactive learning, self-organized learning, learning by discovery, problem learning, comparing data, problem presentation, formulating concepts, summarizing ideas, asking questions, finding examples on the Internet and in literature, written works, providing interesting details, explaining attitudes, discussing a topic, conflicting opinions, discussing pre-set problems. It has been shown that students highly value the accomplished competences re- 
lated to the critical thinking skills and others that fall into the set of competences implied by the concept of intellectual autonomy.

In the factor analysis of didactic instructions effective for provoking metastatements and creative reactions, 10 factors were found in which the observed instructions were categorized. Their contents could be classified under the following names: classification, information control, error analysis, encouragement of flexible approaches, explanation formulation, returning to the given information, analysis of significant moments, assessment of the possibility of reaching the goal, review of previous strategies, forms and additional thinking about relationships and situation.

Gifted students estimate that their professors do not pay enough attention to their intellectual autonomy because they do not use sufficiently didactic strategies and methods that stimulate competences that are at the heart of scientific, critical thinking, which encourage the use of independence in thinking and decision making. Students argue that they do not get enough opportunity to learn how to solve problems and make decisions in the broader options of choice and in discussions and other techniques of inciting autonomy. Achieved competencies with higher average values are mainly those that are significant for intellectual functioning but are not directly related to explains intellectual autonomy and relate to: knowledge of basic concepts, understanding of facts, giving explanations of events.

The possibilities of innovating teaching and learning strategies at the higher education level were analysed especially by examining the application of the method of discourse (Gojkov \& Stojanović, 2011; Stojanović, Gojkov, \& Babić-Kekez, 2013). This method was analysed because it is suitable for the realization of the goals of emancipatory didactics - teaching takes place in way that students are directed towards self-organized searching for information, students independently obtain information for making conclusions, with teacher mentoring in function of student emancipatory potential.

The research carried out in 2011 had an exploratory character, with the intention to consider the possibilities and the effects of discourse application as a method of instruction in higher education teaching (Gojkov \& Stojanović, 2011). The question underlying the research refers to the following: how students assess discourse as a method of instruction, aiming at obtaining the evaluation of the effects of discourse as a method of instruction. The effects of the method implementation have been considered through cognitive reactions of students in learning and teaching situations observed in the discourse. The results of this research contribute by developing different methods of the discourse acceptance as a instruction method by students, 
i.e. its motivational and cognitive aspect, considering the modus higher education didactics has tried to give its contribution to more complete selfobservation and self-reflective, self-guided learning leading to self-changes ensuring freedom of person's actions according to contemporary philosophical discussions aiming to create expected competences and desirable in working in social context today.

We assumed that cognitive reactions of students within a discourse reflect cognition elements relevant for creative approaches to problem solving, flexible, creative, non-dogmatic thinking, as well as ability to accept pluralism of ideas.

The research was undertaken on the sample of 207 students. The independent variable is a discourse as a method of instruction in higher education teaching, and the dependent variables refer to the following: satisfaction with the discourse; cognitive reactions of students; success expressed by the number of points. The method of systematic non-experimental observation was used in the research. Manipulation of variables in order to change them on purpose was not carried out, but statistic replacements were undertaken through statistic analyses for experimental controls.

The following statistic procedures were used: the correlation between the set of variables representing the aspects of satisfaction with a discourse and the number of points was examined according to linear regression analyses, i.e. stepwise method; factor analysis of the aspect of satisfaction with a discourse was carried out according to the method of categorical principal component analysis; factor analysis of the reactions appearing in the discourse was undertaken according to the categorical principal components analysis method; the link between the set of variables referring to satisfaction with a discourse and the set of variables referring to the reactions in the discourse was studied according to the canonical correlation analysis; hierarchical cluster analysis of the variables from the domain of satisfaction with a discourse was carried out through the between-groups linkage method; the hierarchical cluster analysis of the variables from the domain of reactions appearing in a discourse was done in the same way, i.e. using the method of betweengroups linkage. Quadrate Euclidian Distance was used as a cluster distance measure.

Cluster analysis of the satisfaction with a discourse and cognitive reactions appearing in a discourse was carried out in 29 stages (Table 1). According to the table it can also be seen that, for example, at the first stages the variables possibility for taking part in research work and discovery of new ideas were connected in one cluster. 
Table 1 Cluster Analysis Stages

\begin{tabular}{|c|c|c|c|c|c|c|c|}
\hline \multicolumn{2}{|c|}{ Stage Cluster 1} & \multirow{2}{*}{$\begin{array}{r}\text { Cluster } 2 \\
28\end{array}$} & \multirow{2}{*}{$\begin{array}{r}\text { Coefficients } \\
5.000\end{array}$} & \multicolumn{2}{|c|}{ Stage Cluster 1} & \multirow{2}{*}{$\begin{array}{r}\text { Cluster } 2 \\
5\end{array}$} & \multirow{2}{*}{$\begin{array}{r}\text { Coefficients } \\
61.600\end{array}$} \\
\hline 1 & 7 & & & 16 & 4 & & \\
\hline 2 & 7 & 29 & 10.500 & 17 & 11 & 17 & 65.850 \\
\hline 3 & 14 & 15 & 13.000 & 18 & 8 & 11 & 70.389 \\
\hline 4 & 18 & 19 & 18.000 & 19 & 23 & 24 & 75.500 \\
\hline 5 & 7 & 30 & 19.333 & 20 & 1 & 8 & 77.545 \\
\hline 6 & 11 & 13 & 27.000 & 21 & 1 & 4 & 82.275 \\
\hline 7 & 12 & 14 & 28.500 & 22 & 2 & 26 & 92.000 \\
\hline 8 & 5 & 25 & 34.000 & 23 & 3 & 22 & 92.000 \\
\hline 9 & 11 & 12 & 37.833 & 24 & 6 & 21 & 98.000 \\
\hline 10 & 24 & 27 & 39.000 & 25 & 3 & 16 & 98.000 \\
\hline 11 & 8 & 10 & 41.000 & 26 & 1 & 2 & 100.950 \\
\hline 12 & 18 & 20 & 43.000 & 27 & 3 & 23 & 103.556 \\
\hline 13 & 4 & 7 & 43.500 & 28 & 1 & 3 & 106.924 \\
\hline 14 & 1 & 9 & 44.000 & 29 & 1 & 6 & 111.821 \\
\hline 15 & 17 & 18 & 47.667 & & & & \\
\hline
\end{tabular}

Notes The numbers in the columns Cluster 1 and Cluster 2 represent ordinal numbers of the variables from the list of variables in cluster analysis.

The list of variables in cluster analysis:

1. Interesting way of work

2. Motivating for learning

3. Better understanding

4. Freedom of expression

5. Possibility of expressing one's own personal opinion

6. Gradual knowledge acquisition

7. Possibility of research work

8. Opportunity for better grades

9. Possibility of getting into the heart of the matter

10. Work of students more appreciated

11. It is interesting to work in a team

12. Stage-fright due to public discussion as an obstacle

13. The same student always dominate in discussions

14. Preparation of students for each class

15. I prefer professor's lectures to discussions participated by others

16. Data interpretation

17. Deduction of characteristic features of phenomena through analysis

18. Interpretation of data in a new way 
Figure 1

Dendogram

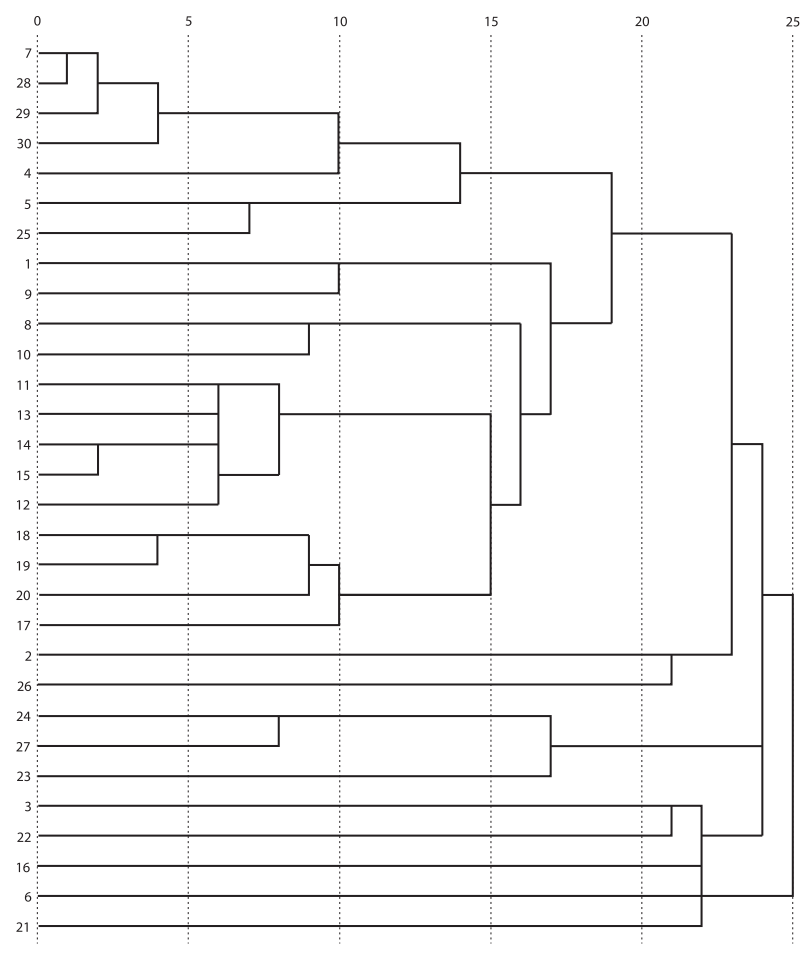

19. Theory analysis and finding way of its application

20. Examples for argumentation of theories

21. Making conclusions

22. Examples for the application of concepts

23. Notional analysis

24. Argumentation

25. Perception of regularities

26. Making a list of characteristic features

27. Comparison of texts

28. Discovery of new ideas

29. Attributing new meanings to data

30. Condensation of main ideas

The dendogram shows the formed clusters clearly indicating that 6 sets of relations between satisfaction with a discourse and cognitive reactions of students within a discourse have been identified. Just like in the previous procedures of analysis, the most emphasized one is the explorative group ( 7 , $28,29,30,45,26)$, closely connecting statements showing satisfaction with a 
possibility to research, as well as that within research discourse the following cognitive reactions were pronounced: attributing new meanings to data, condensation of main ideas in unusual and new way, possibility of expressing one's own ideas, thoughts ... Even though from the angle of frequency the group is smaller, it still remains the most clearly expressed as a correspondent relation between the expression of satisfaction and cognitive reactions that could be classified under a category practical side $(1,9,8,10)$. Furthermore, the variables that could be classified under the category of dissatisfied were also grouped beyond dispute $(1,9,8,10)$, followed by the group manifested through the expression of discontent with a discourse $(11,13,14,15,12)$; this is where it connects with the level of argumentation in the cognitive aspect $(18,19,20,17)$. Furthermore, other clearly grouped variables are classified at the stage of analysis $(2,26,24,27,23)$ and at the level of application $(3,22,16$, $6,21)$.

The findings seem to lead to a conclusion that a discourse as a instruction method in higher education teaching is well accepted, since the students expressed positive attitude towards their statements, i.e. a great deal of positive statements refers to positive sides of a discourse as a method of instruction. The general picture of identifying the aspect convening to them is positive and refers to the satisfaction due to the classes being interesting, motivational aspect of a discourse, possibility to research, express one's own personal opinions and attitudes, etc. This very statement is sufficient for a claim that a discourse can be considered a suitable method of instruction at higher education level. Beyond this it could be concluded that participatory approach permeating a discourse as a method of instruction seems to be the reason for students' satisfaction. That confirm the ideas of participative epistemology in approaches to learning and open way towards encouragement of autonomy and self-regulated learning, as basic elements of emancipatory didactics and cognitive functioning characterised by flexibility, creativity, readiness for risk-taking.

The students with more emphasized cognitive autonomy, research and creative approaches, as a rule, were achieved higher number of points, i.e. they were more successful and had higher achievements.

There is a group of gifted students (whose average in studies is over 9.00) unambiguously identified as those who express satisfaction with a discourse due to possibility to explore, be independent, free, etc. and that they were actually those who manifested success in the form of creative cognitive reactions. This could further mean that a discourse as a method of instruction suits them best and that other students need additional work in order 
to adopt strategies implied by participatory epistemology and to get more focused emancipatory aims of learning in higher education teaching. Discourse is one of possible ways, at least according to the findings of this research, as a method of instruction in higher education teaching. At it has already been pointed out, it cannot be considered a universal method, either from the angle of contents or from the angle of significant cognitive differences, learning strategies differences, etc.

In our second research (Stojanović et al., 2013), the possibilities of innovating teaching and learning strategies at the higher education level have been analysed by examining the application of the discourse method. The sample consisted of 564 students from the University of Belgrade. Main question of this research was about how consistent the cognitive and learning styles are with the discourse method. In this context, the method of discourse, that is, its effectiveness depends on the cognitive and learning styles, and within that, from the formed learning strategies, in order to answer the question about the possibilities and effects of using discourses as a method of teaching in higher education. The thesis about the influence of learning style on the acceptance of discourse as a method in higher education was tested, which examined the question of the efficiency factor of the method of discourse, its motivational and cognitive aspect, and the ways in which higher education didactics are trying to contribute to a more complete self-reflexive, self-directed learning towards self-changes in order to secure freedom personality performance.

It turned out that students who express satisfaction with discourse and have cognitive reactions in learning and teaching situations that are in the discourse (creative approaches to problem solving, flexible, creative, nongrammatical thinking in discussions on the issues being discussed, openness to different ideas, tolerance of uncertainty, initiative, risk readiness) as reasons for satisfaction: the possibilities of exploration, independence, freedom, etc., and manifest success in the form of creative cognitive reactions.

It was noted that discourse as a method corresponds to most gifted students (whose average in studies is over 9.00). But, at the same time, the majority of the students do not present self-organized learning leading to intellectual autonomy. They do not have ability to observe the reading text in whole as a characteristics of learning style, posting questions after text, synthesizing, comparing with other ideas, placing them in a real context-finding a case, searching for better ways to present content, re-writing ideas, questions about the ways of an easier way to learn something, learn, critically review, evaluate their own strategies, etc. Their metacognitive components 
are not developed (sufficiently), and their motivation is not intrinsic (learning for points and grades, from sketches, theses, and in some cases even by implication). Students, unaccustomed to self-organized learning, searching for answers, asking questions and their argumentation, feel uncomfortable in discussions in the group. So, for that reason it could be concluded that method of discourse was not accepted in this mentioned group of students. That students do not take enough ability of self-organized learning. The previous findings point to the conclusion that the realization of the Bologna process can contribute to essential didactic-methodical innovations for learning approaches, taking into account complex cognitive structures such as cognitive style. The characteristics of the cognitive style that relate to students' satisfaction with the method of discourse and their successful cognitive reactions are: independence, attention selection, unconventional reinterpretation, convergent production, flexible control, divergent production, imagination, creative generalization, discrepancy tolerance.

\section{Conclusion}

Gifted students should focus on effective self-learning that results in the development of intellectual abilities and autonomy. Therefore, in higher education it is necessary to insist on student participation, co-decision, research and interdisciplinarity as elements of emancipatory learning. Empirical checks of the scope and limitations of the application of innovative potentials of modern methods in higher education (Gojkov, 2013; Gojkov et al., 2015), from the point of stimulating the metacognitive abilities of gifted students and intellectual autonomy, support the conclusion that metacognitive approaches to learning of gifted students related to ICT technology in the process of self-study and research procedures. This is particularly evident in the application of the discourse method, as students consider it more effective than classical academic presentations, because they can do a lot of research, independently access information by networking with students around the world, consulting in the search for resources etc. The importance of ICT technology contributes to the development of intellectual autonomy of gifted students, as they have the opportunity to prepare original arguments for new angles of questions that are asked, or which they set themselves, for discussions in lectures, exercises, and seminars. Thus, the boundaries are being erased and it enables the realization of the idea of participative epistemology in the attainment of learning, and this opens up the path to enabling autonomy and self-regulated learning. The gifted are aware of this and use that commonly.

Gifted students in their expectations have emphasized the greater need 
for teaching methods and didactic constructions that stimulate curiosity, good information, verifiability of reason, openness of thought, flexibility, confrontation of personal prejudices, caution in decision-making, willingness to reconsider, clarity in questions, order in complex matters, diligence in searching for relevant information, responsibility in classifying criteria, focusing on search and persistence in seeking solutions, experiment planning, generalizing findings, evaluating products, applying ideas, expressing sceptical thinking, natural-scientific thinking, expressing cross-thinking and expression self-reflexive thinking. All this indicates that gifted students feel the importance of cognitive competence, as well as affective dispositions - they understand the importance of the processual and dispositional side of critical thinking. It could be concluded that higher education teachers should work with gifted students to apply strategies, methods and instructions that will be formulated by intellectually autonomous individuals who think critically.

Also, gifted students respond to the creation of a culture of discussion in higher education in which they will be able to partner in professional discussions to develop their intellectual potentials, critical thinking, metacognitive abilities, creativity, etc.

The participatory approach, which is basically the discourse behind the manifest satisfaction of most gifted students, confirms the ideas of participatory epistemology in learning approaches and opens the way to fostering autonomy and self-regulated learning, as the basic elements of emancipatory didactics and cognitive functioning that should be characterized by flexibility, creativity, readiness to take risks. Findings also point to the conclusion that it is necessary to individualize approaches because method of discourse is not accepted in the same way and range by all students.

\section{References}

Brookfield, S. D. (1987). Developing critical thinkers: Challenging adults to explore alternative ways of thinking and acting. San Francisco, CA: Jossey-Bass.

Đurišić-Bojanović, M. (2008). Multikulturalnost i multiperspektivnost u obrazovanju [Intercultural and multi perspective in education]. In J. Šefer, S. Joksimović \& S. Maksić (Eds.), Uvažavanje različitosti i obrazovanje [Appreciation of diversity and education] (pp. 45-71). Beograd, Serbia: Institut za pedagoška istraživanja.

Eberhardt, U. (Ed.) (2010). Neue Impulse in der Hochschuldidaktik [New impulses in university didactics]. Berlin, Germany: VS Verlag.

Flavell, J. H. (1979). Metacognition and cognitive monitoring: A new area of cognitive-development inquiry. American Psychologist, 34(10), 906-911.

Gojkov, G. (2013). Fragmenti visokoškolske didaktike [Fragments of higher edu- 
cation didactics]. Vršac, Serbia: Visoka škola strukovnih studija za vaspitače 'Mihailo Palov'.

Gojkov, G., Gojkov-Rajić, A., \& Stojanović A. (2014). Heurističke didaktičke strategije u visokoškolskoj nastavi [Heuristic didactic strategies in higher education]. Vršac, Serbia: Visoka škola strukovnih studija za vaspitače 'Mihailo Palov'.

Gojkov, G., \& Stojanović A. (2011). Participativna epistemologija u didaktici [Participatory epistemology in didactics]. Vršac, Serbia:Visoka škola strukovnih studija za vaspitače 'Mihailo Palov'

Gojkov, G., Stojanović A., \& Gojkov-Rajić, A. (2015). Didactic strategies and competencies of gifted students in the digital era. CEPS Journal, 5(2), 57-73.

Heller, K. A. (2001). Gifted education at the beginning of the third millenium. Australian Journal of Gifted Education, 10, 48-61.

Kruse, O. (2011). Kritičko razmišljanje u znaku Bologne: retorika i realnost [Critical thinking in the sign of Bologna: Rhetoric and reality]. In M. Rumller (Ed.), Neue Impulse in Hochschuldidaktik [New impulses in university didactics] (pp. 53-67). Berlin, Germany: VS Verlag.

Lissmann, K.P. (2006). Theorieder Unbildung:Die Irrtumer der Wiesensgesellschaft [Theory of Unbildung: The Errors of the Knowledge Society]. Vienna, Austria: Zsolnay.

Paul, R., \& Elder, L. (2003). Kritishes Denken, Begriffe und Instrumente [Critical thinking, concepts and instruments]. Retrieved from https://www .criticalthinking.org/files/german_concepts_tools.pdf

Robinson, N. M. (1993). Parenting the very young gifted child. Storrs, CT: National Research Center on the Gifted and Talented.

Shore, B., \& Kanevsky, L. (1993). Thinking processes: Being and becoming gifted. In K. A. Heller, F. J. Mönks, \& A. H. Passow (Eds.), International handbook for research and development on giftedness and talent (pp. 133-148). London, England: Pergamon.

Sternberg, H. (1988). The triarchic mind: A new theory of human intelligence. New York, NY: Viking.

Stojanović, A., \& Gojkov, G. (2016). Creativity and metacognition as indicators of higher education. Interdisciplinary Management Research, 12, 773-782.

Stojanović, A., Gojkov G., \& Babić-Kekez S., (2013). Cognitive and learning styles and a method of discourse in higher education teaching. Procedia: Social and Behavioral Sciences, 93, 762-774.

Waldmann, M. \& Weinert, F. E. (1990). Intelligenz und Denken: Perspektiven der Hochbegabungsforschung [Intelligence and thinking: Perspectives of giftedness research]. Göttingen, Germany: Hogrefe.

Zervakis, P. \& Wahlers, M. (2007). Education for sustainable development and Bologna process: The implementation of the Bologna process in Germany. Retrieved from http://bne-portal.de 


\title{
How Kindergarten Teachers Perceive Giftedness and What They Require for Their Work with Gifted Preschool Children
}

\author{
MIB d.o.o., Slovenia \\ maruska@mib.si \\ Borut Seničar \\ MIB d.o.o., Slovenia \\ borut.senicar@mib.si
}

Maruška Željeznov Seničar

The present study suggests that teachers hold a variety of views regarding the potential giftedness of preschool children. These views differ within and between the two countries studied, as well as between generations. The participants in the study expressed their position, from most to least, on the qualitative, multi-category, comparative and holistic concepts of giftedness. Jointly and in each country separately, the teachers regard the role of parents in identifying potential giftedness as more important than their own. The study shows that the identification of gifted preschool children is regarded as important by $95.7 \%$ of Croatian teachers and $75 \%$ of Slovenian teachers, and that $67.74 \%$ of Croatian teachers and $41.89 \%$ of Slovenian teachers identified potentially gifted preschool children in the course of their work. They characterised their ability to identify potentially gifted children as 'I can usually recognise a gifted child' and 'I know how to recognise a gifted child.' Over half the respondents stated that they did not work in a systematic way with gifted preschool children. They pointed out that they required training in identifying and working with potentially gifted preschool children, materials, teaching strategies, approaches to identification and adequate legislation.

Keywords: kindergarten teachers, perception of giftedness, gifted children, identification, teaching strategies

\section{Introduction}

\section{Perception of Giftedness}

According to Moon (2006), definitions of giftedness can be conceptual or operational. Conceptual definitions are frequently based on theory and research, e.g. the Three-Ring Conception of Giftedness (Renzulli, 1986) and the Differentiated Model of Giftedness and Talent (DMGT) (Gagné, 2003, 2005). Operational definitions are more practical and give guidelines for formulat- 
Table 1 Respondents Concepts and Definition of Giftedness

\begin{tabular}{ll}
\hline Concepts and definitions/Respondent quotes \\
\hline $\begin{array}{l}\text { Multi-category } \\
\text { definition }\end{array}$ & $\begin{array}{l}\text { Children can be gifted in different aspects/ways, such as mathematically, } \\
\text { linguistically, musically, socially. It is therefore hard to give percentages } \\
\text { for gifted children. }\end{array}$ \\
\hline Holistic & $\begin{array}{l}\text { A 'multiple intelligences' approach makes for a more holistic view of gift- } \\
\text { edness; a holistic assessment is therefore critical, both in EC (early child- } \\
\text { hood) and primary education. }\end{array}$ \\
\hline Comparative & $\begin{array}{l}\text { Gifted children are those who demonstrate abilities above those of their } \\
\text { peer group; they might also be children who demonstrate the potential } \\
\text { to achieve above their peers. }\end{array}$ \\
\hline Intellectual & $\begin{array}{l}\text { A gifted child is a child who has an intellectual grasp of ideas or concepts, } \\
\text { and who can put them into action, or extend the theories beyond the re- } \\
\text { gurgitation of facts. }\end{array}$ \\
\hline Egalitarian & $\begin{array}{l}\text { I believe that, given the right environment, every child has the potential } \\
\text { to be gifted. }\end{array}$ \\
\hline Not labelling & I am wary of labelling and aim to foster every child's strengths. \\
\hline Qualitative & $\begin{array}{l}\text { Gifted children are those who learn faster, see things in different ways } \\
\text { from their peers, exhibit curiosity and understanding that exceeds the cu- } \\
\text { riosity and understanding of others, feel emotions intensely and do not } \\
\text { fit in easily. If many of these characteristics are present in one child, which } \\
\text { indicates giftedness to me. }\end{array}$ \\
\hline
\end{tabular}

Notes Adapted from Margrain and Farquhar (2012).

ing programmes for educating and raising gifted children (Moon, 2006). Operational definitions provide answers to specific questions: which children, which programmes, when and where these programmes are to be provided, and who should provide them (Robinson, 2016).

The study uses the seven concepts and definitions model produced by Margrain and Farquhar (2012) in their national study for New Zealand. Their research suggested seven giftedness concepts and definitions: multi-category, holistic, comparative, intellectual, egalitarian, not labelling and qualitative. This approach of differentiation was used in New Zealand's first survey of research into the education of gifted children aged eight or under.

\section{Identification of Gifted Preschool Children}

The identification of gifted children in early childhood is a subject of intense debate when it comes to work with potentially gifted and talented children. European Economic and Social Committee (2013) proposes that the development and potential of highly gifted children and young people should be fostered at all levels and in all forms of education, where premature special- 
isation should be avoided, respect for diversity in school settings supported and possibilities of offering group learning and informal education exploited (European Economic and Social Committee, 2013, p. 1). A variety of terms are used for the concept of the gifted and talented preschool child: early giftedness, talent, potential giftedness, above-average giftedness, and other terms that indicate high ability and pronounced talent in the preschool period.

Like the concepts, the process of identifying potentially gifted preschool children is a wide area of discussion, with debates continuing on what that process should cover, how it should be implemented and at whom it should be aimed. The term 'potential giftedness of preschool children' is used in both Slovenia and Croatia.

Preschool environments contain teachers from at least three generations: Baby Boomers, Generation X and Generation Y. Each generation is marked by different values, attitudes to work and life experiences. The Baby Boom generation was born between 1946 and 1964, Generation X between 1964 and 1985, and Generation Y after 1985 (Zemke, Raines, \& Filipczak, 2000). Regarding the differing values of the generations, the study looks at whether there are differences between the generations in terms of their understanding of the concept of giftedness and whether these differences might significantly affect the implementation of different concepts in preschool work. No research has yet been carried out in this area.

\section{Needs of Kindergarten Teachers in Working with Gifted Children}

European Economic and Social Committee (2013) lists the main factors affecting the approach to the development of highly gifted children and young people: recognising and monitoring highly gifted pupils (e.g. identification), legislation, teaching provision (teaching approaches and materials) and teacher training.

If work with preschool children is to reach the requisite quality, a teaching and schooling environment must be established that, according to the Slovenian Curriculum for Kindergartens (Kurikul za vrtce, 1999), enables optimal development and, according to the Croatian Curriculum for Kindergartens (2014, p. 26), fosters the comprehensive development of the preschool child. Neither curriculum defines the concept of giftedness and the identification thereof in the preschool period; at the same time, however, both do allow a subjective interpretation of the goals of the curriculum, and provide teachers with options for individualising and differentiating the education process in line with the education needs of the child. 


\section{Research Methodology \\ Design}

The survey was an 11-item online questionnaire. Respondents were asked for their gender, date of birth, years of service, beliefs regarding giftedness, an assessment of their ability to identify potential giftedness in a preschool child and to work with potentially gifted children, their perception of their role and the role of parents in the identification process, their ability to identify gifted young children, their beliefs regarding their work with gifted children, and an assessment of what they required for high-quality work with potentially gifted preschool children.

\section{Research Questions}

- Perception of giftedness

1. Are there differences in teachers' perception of giftedness between and within countries?

2. Are there intergenerational differences in teachers' perception of giftedness between and within countries?

- Identification of gifted preschool children

3. Are there differences in the opinions of educators regarding the early identification of gifted preschool children between and within countries?

4. What approaches are used to identify gifted preschool children?

- Needs of kindergarten teachers in working with gifted children

5. What are the needs of kindergarten teachers in working with gifted preschool children in a specific country? What are the differences between the countries?

\section{Respondents}

Responses were received from 241 teachers ( 148 from Slovenia, 93 from Croatia). The survey was made available through kindergarten networks in Slovenia and Croatia between June and August 2017. All respondents work as kindergarten teachers with children aged between one and six years.

\section{Results}

\section{Perception of Giftedness}

Across all respondents in the study, the qualitative approach to giftedness predominates $(30.29 \%)$, followed by the multi-category approach (16.6\%), 


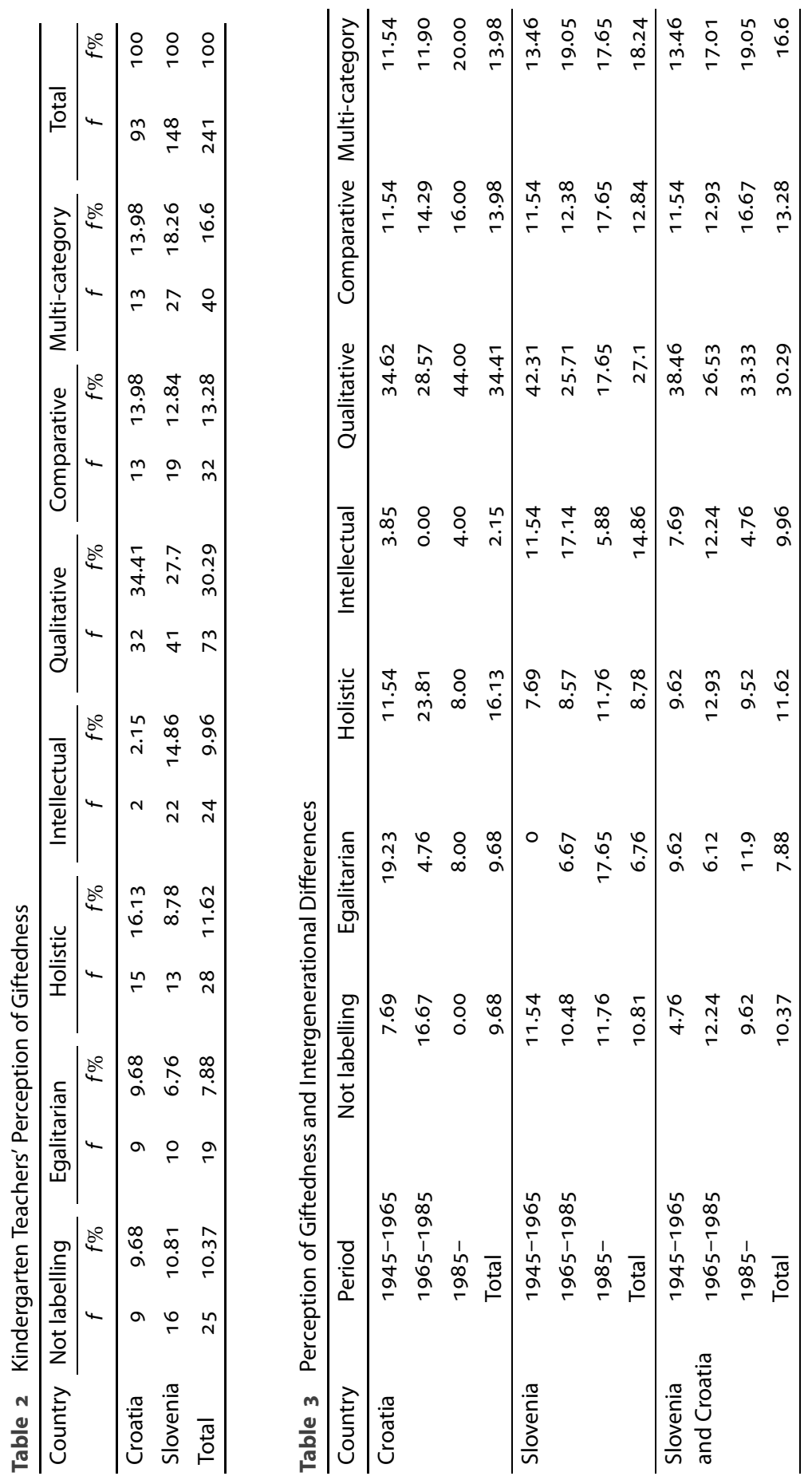


the comparative approach (13.28\%), the holistic approach (11.62\%), the 'not labelling' approach (10.37\%), the intellectual approach (9.96\%) and the egalitarian approach (9.96\%). There are differences between the two countries. A higher percentage of Slovenian teachers took an intellectual approach to giftedness and a higher percentage of Croatian teachers took a holistic approach to giftedness.

\section{Perception of Giftedness and Intergenerational Differences}

Kindergartens contain teachers from at least three generations. Each generation is characterised by different values and attitudes to work, schooling and education.

Several differences can be perceived in both countries:

- The percentage of Generation X members taking the 'not labelling' approach is higher than the average for this category;

- The percentage of Generation X members taking the intellectual approach is higher than the average for this category;

- The percentage of Generation Y members taking the comparative approach is higher than the average for this category;

- The percentage of Generation Y members taking the intellectual approach is lower than the average for this category.

A comparison between the two countries addressed in the study shows that:

- The percentage of Generation X members taking the 'not labelling' approach is higher in Croatia than in Slovenia;

- The percentage of Baby Boomers taking the egalitarian approach is higher in Croatia than in Slovenia;

- The percentage of Generation X members taking the intellectual approach is higher in Slovenia than in Croatia;

- The percentage of Generation Y members taking the qualitative approach is higher in Croatia than in Slovenia.

There are generational differences in the perception of giftedness within countries as well.

Slovenia:

- The percentage of Generation Y members taking the egalitarian approach is higher than other generations; 
Table 4 Importance of Identifying Potential Gifted Preschool Children

\begin{tabular}{lrrrrrrrrr}
\hline Country & \multicolumn{2}{c}{ Yes } & & \multicolumn{2}{c}{ No } & & \multicolumn{2}{c}{ Total } \\
\cline { 2 - 3 } \cline { 8 - 9 } & $f$ & $f \%$ & & $f$ & $f \%$ & & $f$ & $f \%$ \\
\hline Croatia & 89 & 95.70 & & 4 & 4.30 & & 93 & 100.00 \\
Slovenia & 111 & 75.00 & & 37 & 25.00 & & 148 & 100.00 \\
Total & 200 & 82.99 & & 41 & 17.01 & & 241 & 100.00 \\
\hline
\end{tabular}

- The percentage of Generation X members taking the intellectual approach is higher than other generations (the difference is particularly marked between Generation X and Generation Y);

- The percentage of Baby Boomers taking the qualitative approach is higher than other generations (the difference is particularly marked between the Baby Boom generation and Generation Y).

\section{Croatia:}

- The percentage of Generation X members taking the 'not labelling' approach is higher than other generations (the difference is particularly marked between Generation X and Generation Y, none of whom take the 'not labelling' approach);

- The percentage of Baby Boomers taking the egalitarian approach is higher than other generations (the difference is particularly marked between the Baby Boom generation and Generation X);

- The percentage of Generation X members taking the holistic approach is higher than other generations (the difference is particularly marked between Generation X and Generation Y);

- No members of Generation X take the intellectual approach;

- The percentage of Generation $Y$ members taking the qualitative approach is higher than other generations.

The results do not allow us to outline any joint characteristics within specific generations, either within the two countries as taken together or within the countries themselves.

Identification of Potentially Gifted Preschool Children. Identifying potentially gifted preschool children was important to $82.99 \%$ of respondents (and therefore not important to $17.01 \%$ of respondents). A comparative analysis of the two countries shows that $95.7 \%$ of Croatian respondents and $75 \%$ of Slovenian respondents regarded identification as important (i.e. $25 \%$ of Slovenian respondents did not regard it as important). The differences in 
Table 5 Method of Identifying Potential Gifted Preschool Children

\begin{tabular}{lrrrrrrrr}
\hline Country & \multicolumn{2}{c}{ Yes } & & \multicolumn{2}{c}{ No } & & \multicolumn{2}{c}{ Total } \\
\cline { 2 - 3 } \cline { 8 - 9 } & $f$ & $f \%$ & & $f$ & $f \%$ & & $f$ & $f \%$ \\
\hline Croatia & 63 & 67.74 & & 30 & 32.26 & & 93 & 100.00 \\
Slovenia & 62 & 41.89 & & 86 & 58.11 & & 148 & 100.00 \\
Total & 125 & 51.87 & & 116 & 48.13 & & 241 & 100.00 \\
\hline
\end{tabular}

the perceptions of giftedness might be the result of a difference in the way that identification of gifted preschool children is understood. The concept of identification is a wide one and can encompass different activities, including observation techniques, interviews and measuring instruments (tests).

Do You Identify Potentially Gifted Children in the Course of Your Work? Potentially gifted preschool children were identified by $51.87 \%$ of respondents (48.13\% of respondents did no such identification). A comparative analysis indicates that more teachers engage in the identification of potential giftedness in Croatia than in Slovenia (67.74\% vs $41.89 \%)$. Within Slovenia, more teachers do not identify than identify potentially gifted children $(58.11 \%)$. The concept of identification is a wide one and can encompass different activities, including observation techniques, interviews and measuring instruments (tests). Respondents mentioned various approaches to identifying giftedness: observation, monitoring a child's development and recording their progress, enriched study programmes, collaboration with external experts, observation checklists, questionnaires and cooperation with parents.

How Do You Perceive Your Role in Identifying Potentially Gifted Preschool Children? Of the respondents, $48.96 \%$ said their role was important, $29.46 \%$ said it was more important and $14.94 \%$ said it was very important. A comparative analysis between the two countries shows that teachers regard their role in identifying gifted preschool children as important, and that there are no major differences between Croatian and Slovenian teachers in this regard.

How Do You Perceive the Role of Parents in Identifying Potential Giftedness in Their Preschool Child? Across the range of respondents, teachers saw parents as having a more important role in identifying the potential giftedness of their preschool child than their own. A comparative analysis shows that Croatian teachers are more inclined than Slovenian teachers to see parents as having a more important role.

How Do You Perceive Your Ability to Identify Potential Giftedness in a Preschool Child? With regard to their ability to identify a potentially gifted child, $73.86 \%$ 


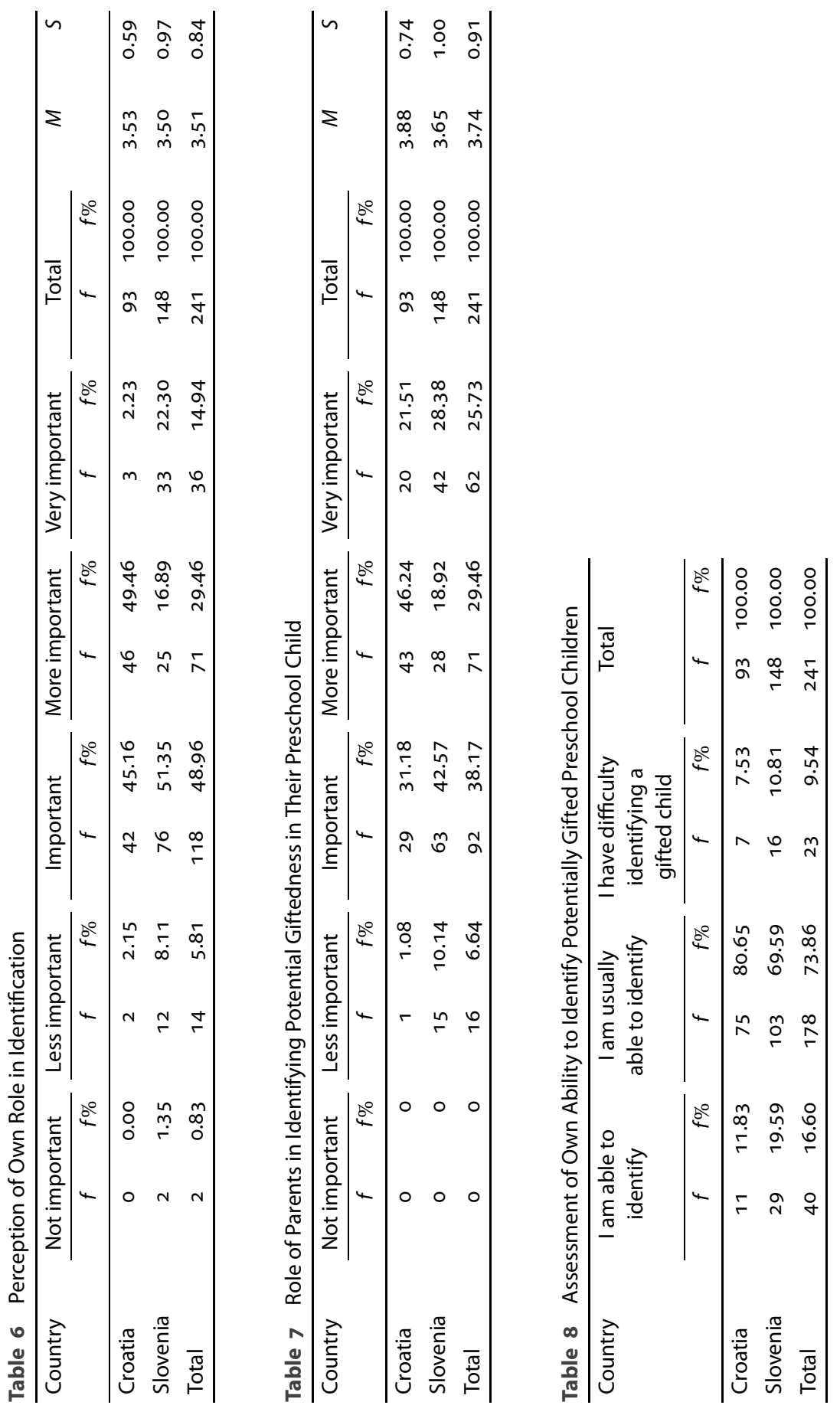


Table 9 Assessment of Work with Potentially Gifted Preschool Children

\begin{tabular}{|c|c|c|c|c|c|c|c|c|c|c|}
\hline \multirow[t]{2}{*}{ Country } & \multicolumn{2}{|c|}{$\begin{array}{l}\text { No work is } \\
\text { done with } \\
\text { gifted } \\
\text { preschool } \\
\text { children }\end{array}$} & \multicolumn{2}{|c|}{$\begin{array}{l}\text { Work is only } \\
\text { rarely done } \\
\text { with gifted } \\
\text { preschool } \\
\text { children }\end{array}$} & \multicolumn{2}{|c|}{$\begin{array}{l}\text { The } \\
\text { importance of } \\
\text { working with } \\
\text { gifted } \\
\text { preschool } \\
\text { children is } \\
\text { slowly being } \\
\text { recognised }\end{array}$} & \multicolumn{2}{|c|}{$\begin{array}{l}\text { We work } \\
\text { systematically } \\
\text { at the } \\
\text { kindergarten } \\
\text { to identify } \\
\text { gifted } \\
\text { preschool } \\
\text { children and } \\
\text { work with } \\
\text { them }\end{array}$} & \multicolumn{2}{|c|}{ Total } \\
\hline & $f$ & $f \%$ & $f$ & $f \%$ & $f$ & $f \%$ & $f$ & $f \%$ & $f$ & $f \%$ \\
\hline Croatia & 50 & 53.76 & 24 & 25.81 & 14 & 15.05 & 5 & 5.38 & 93 & 100.00 \\
\hline Slovenia & 76 & 51.35 & 43 & 29.05 & 13 & 8.78 & 16 & 10.81 & 148 & 100.00 \\
\hline Total & 126 & 52.28 & 67 & 27.80 & 27 & 11.20 & 21 & 8.71 & 241 & 100.00 \\
\hline
\end{tabular}

Table 10 Assessment of Work with Gifted Preschool Children

\begin{tabular}{|c|c|c|c|c|c|c|c|c|c|c|}
\hline \multirow[t]{2}{*}{ Country } & \multicolumn{2}{|c|}{ Legislation } & \multicolumn{2}{|c|}{$\begin{array}{l}\text { Approaches to } \\
\text { identification }\end{array}$} & \multicolumn{2}{|c|}{$\begin{array}{l}\text { Teaching } \\
\text { approaches }\end{array}$} & \multicolumn{2}{|c|}{$\begin{array}{l}\text { Teaching } \\
\text { materials }\end{array}$} & \multicolumn{2}{|c|}{ Education } \\
\hline & $M$ & $S$ & $M$ & $S$ & $M$ & $S$ & $M$ & $S$ & $M$ & $S$ \\
\hline Croatia & 3.22 & 1.01 & 3.54 & 0.87 & 3.94 & 0.87 & 3.9 & 0.85 & 3.98 & 0.86 \\
\hline Slovenia & 2.67 & 1.22 & 3.32 & 1.11 & 3.58 & 1.12 & 3.63 & 1.05 & 3.88 & 1.02 \\
\hline Total & 2.88 & 1.12 & 3.4 & 1.03 & 3.71 & 1.04 & 3.73 & 0.96 & 3.91 & 0.96 \\
\hline
\end{tabular}

of respondents stated that they were usually able to do so, $16.6 \%$ stated that they were always able to do so and $9.54 \%$ stated that they had difficulty doing so. A comparative analysis shows that $80.65 \%$ of Croatian teachers and $69.59 \%$ of Slovenian teachers regard themselves as being able to identify a potentially gifted child.

How Do You Assess the Work Performed in Your Kindergarten with Potentially Gifted Preschool Children? In Slovenia and Croatia together, 52.28\% of teachers stated that no systematic work was performed with potentially gifted preschool children, $27.8 \%$ stated that work was rarely performed and $11.2 \%$ stated that the importance of work with potentially gifted children was slowly being recognised. A comparative analysis shows that $10.81 \%$ of Slovenian teachers believe that they work with potentially gifted preschool children in a systematic manner, compared with only $5.38 \%$ of Croatian teachers.

Needs of Kindergarten Teachers in Working with Potentially Gifted Children At the level of the study as a whole, teachers expressed the greatest need for training in identifying and working with potentially gifted preschool chil- 
dren, followed by materials, teaching approaches, approaches to identification and, in last position, proper legislation. Teachers' needs were distributed evenly among the Slovenian respondents, while Croatian teachers expressed a greater need for teaching materials than did their Slovenian counterparts.

\section{Discussion}

The study shows a variety of views regarding giftedness within and between the two countries, as well as between generations. A qualitative definition of giftedness was favoured by $30.29 \%$ of respondents, meaning that giftedness was examined from the developmental aspect, the child's potential to learn, and the child's curiosity and level of interest. The multi-category approach, where children may be gifted in different areas that are difficult to define, was favoured by $16.6 \%$ of respondents. The comparative approach, which ranks children's abilities and achievements in comparison with their peers, was favoured by $13.28 \%$ of respondents, and the holistic approach by $11.62 \%$ of respondents. The qualitative, multi-category, comparative and holistic approaches to child giftedness look at a child in developmental terms and not in terms of 'uniqueness.' This awareness is important for introducing concepts of giftedness at the national level and designing teacher training for work with gifted preschool children. The results show that the development of approaches to identification has to encompass a child's whole personality and not only place it within the context of their future development. The results point towards the training of teachers to recognise the characteristics of a potentially gifted preschool child, and the establishment of an education and teaching environment that enables children to develop their potential, gifts and talents.

In both countries, teachers perceive the role of parents in identifying giftedness as more important than their own. This points towards a more comprehensive and inclusive approach to identifying gifted preschool children and working with them - one that includes the family, the kindergarten and the wider environment. One of these approaches is the System Approach, which is deployed in the Dutch system of Leiden.

The study shows that the identification of potentially gifted preschool children is regarded as important by $95.7 \%$ of Croatian teachers and $75 \%$ of Slovenian teachers. The process of recognising and identifying giftedness is a wide concept that should include all children and all possible approaches to observation with the aim of establishing every child's educational needs in relation to their areas of strength, potential or talent. With regard to the concept of individualisation and differentiation of the curriculum, an individ- 
ualised programme can be designed for a child with exceptional abilities or gifts in support of teaching work with the child at kindergarten, in a family setting and in the wider environment.

The study shows that $67.74 \%$ of Croatian teachers and $41.89 \%$ of Slovenian teachers identify gifted preschool children in the course of their work. This result is an argument for further research to be undertaken into the content, process and goals of identification. The objective of identification should be to identify children's education needs, which is realised, in conjunction with a child's interests and wishes, through teaching and education work. Respondents characterised their ability to identify gifted children as 'I can usually recognise a gifted child' and 'I know how to recognise a gifted child.'

Over half the participants stated that they did not work in a systematic way with potentially gifted preschool children. Regarding their work, they pointed out that they most required training in identifying and working with gifted preschool children, materials, teaching strategies, approaches to identification and adequate legislation.

The results of the study generate a number of questions that could be addressed in future research work, such as:

- How teachers conceptualise the process of identifying giftedness in preschool children and what such conceptualisation consists of;

- What specific procedures are used in practice in work with gifted preschool children;

- What specific content would be required in the education process for identifying and working with gifted children.

The results of this study offer proposals for making improvements to the recognition of potentially gifted preschool children, and to education and teaching work at both the systemic and operational levels. A systemic approach that offers kindergartens and families every support in early-years work with the potential, gifts and talents of preschool children must be established to enable us to adequately identify potential gifted preschool children and work with them. This approach contains social awareness of the importance of nurturing individuals' gifts and talents via the lifelong learning concept, which requires a concept of continuity at the national level, from kindergarten to the Third Age, as well as systemic infrastructural support for families, schooling and educational institutions and all other organisations to identify, develop and work with gifts and talents. The recognition and identification of gifts and talents should be sufficiently open as to support the lifelong learning concept (e.g. we can develop and display some talents as 
we get older) and enable every individual to achieve self-realisation in life through willpower, motivation, work and learning.

\section{Conclusions}

Recognising and identifying potentially gifted preschool children, and working with them, should be part of nationwide, systemic concept of the development of gifted and talented people within the terms of the concept of lifelong development and learning. This entails a sufficiently open space for recognising and developing giftedness and talent that does not involve merely identifying gifts and talents but also identifying the educational, social and emotional needs of individuals so as to support their development. Early identification of giftedness by defining it in a child's early years can be a 'trap' for those we identify, as well as for those we do not. As a result, teachers and other educators must be given high-level training to conduct the identification process and interpret the information obtained with due care, and with due regard to the ethical dimension as regards the child's development and learning potential. The study shows that teachers are split between need (an awareness that it is important), an ethical dilemma (which concept or approach to choose) and reality (they need more training).

Professional and scientific cooperation should begin within the framework of the giftedness concept at an early age. There is a need for cooperation between different professionals, psychologists, educators, kindergarten teachers and everyone involved in the life of young children.

\section{References}

European Economic and Social Committee. (2013). Opinion of the European Economic and Social Committee on unleashing the potential of children and young people with high intellectual abilities in the European Union ( $\mathrm{SOC} / 445-$ EESC-2012-963). Brussels: Author.

Gagné, F. (2003). Transforming gifts into talents: The DMGT as a developmental theory. In N. Colangelo \& G. A. Davis (Eds.), Handbook of gifted education (3rd ed., pp. 60-74). Boston, MA: Allyn and Bacon.

Gagné, F. (2005). From gifts to talents: The DMGT as a developmental model. In R. J. Sternberg and J. E. Davidson (Eds.), Conceptions of giftedness (2nd ed., pp. 98-119). New York, NY: Cambridge University Press.

Kurikul za vrtce [Curriculum for kindergartens]. (1999). Ljubljana: Zavod za šolstvo.

Margrain, V., \& Farquhar, S. (2012). The education of gifted children in the early years: A first survey of views, teaching practices, resourcing and administration issues. APEX: The New Zealand Journal of Gifted Education, 17(1), 1-13. 
Moon, S. M. (2006). Developing definition of giftedness. In J. H. Purcell \& R. D. Eckert (Eds.), Designing services and programs for high-ability learners: A guide-book for gifted education (pp. 23-31). Thousand Oaks, CA: Corwin Press.

Renzulli, J. S. (1986). The three-ring conception of giftedness. In R. J. Sternberg \& J. E. Davidson (Eds.), Conception of giftedness (pp. 53-92). New York, NY: Cambridge University Press.

Robinson, A. (2016). Conceptual framework for gifted education services. Retrieved from http//ualr.edu/gifted/research

Zemke, R. M, Raines, C., \& Filipczak, B. (2000). Generations at work: Managing the clash of veterans, boomers, xers, and nexters in your workplace. New York, NY: American Management Association. 


\title{
Fostering Mathematically Gifted Students with Complex Fields of Problems
}

\author{
Marianne Nolte \\ University of Hamburg, Germany \\ marianne.nolte@uni-hamburg.de
}

\begin{abstract}
The article focuses on the importance of learning environment for mathematically gifted students. At the University of Hamburg we developed mathematical problems which can be solved on different levels. They are appropriate to be extended to fields of problems, when students ask further leading questions. Working on these kinds of problems students develop their mathematical competencies. Due to their possibility of working on the problems on different levels they are suitable for fostering mathematically talented students on primary grade level and on secondary level. Based on an example the report defines the character of the kind of problems.
\end{abstract}

Keywords: mathematical gifted students, progressive research problems, learning environments

\section{Introduction}

At the University of Hamburg we foster mathematically gifted students within the framework of the Project called PriMa, ${ }^{1}$ starting with about 8 years old students. With 7 th grade they may continue within the framework of the William-stern society which fosters students until the end of the upper secondary level. We developed problems which can be extended to fields of problems. Most of those problems can be solved on different levels. Some of them can be used as well with primary grade students as with students at secondary and upper secondary level. At upper secondary level sometimes students even develop small mathematical theories. These characteristics make it possible to use the problems with students of different levels as well of age as of levels of potential. One main requirement from that is that teachers handling the problems, can notice the students' needs, including their cognitive components in problem solving, in a sensible way.

\section{High Mathematical Potential and Problem Solving}

The most common approach of fostering students with a high mathematical potential is let them do problem solving. Problem solving requires indepen-

\footnotetext{
${ }^{1}$ PriMa is a cooperation project of the Hamburger Behörde für Schule und Berufsbildung, and the William-Stern Society (Hamburg), the University of Hamburg.
} 
dent work on mathematical questions. Due to the characteristic of problem solving, the solution cannot be found by an algorithm and, there is a barrier a student has to overcome. Problem solving demands flexible thinking, endurance and creativity. So, high achievement in solving complex mathematical problems provides one of the main indications of the capacity of a student. But, especially at primary grade level, even students with a high mathematical potential may not be able to show high achievement due to their experience, or lack of experience, in the field of problem solving.

In accordance with theoretical considerations about giftedness, extraordinary performance is the result of the interplay between inherited potentials, proposals and conditions given by the environment plus intrapersonal variables like interest and motivation. The activities of a student in a certain subject shape the development of a potential to a competence (e.g. Gagné, 2004; Heller, 2004; Singer, Sheffield, Freiman, \& Brandl, 2016; Subotnik, OlszewskiKubilius, \& Worrell, 2011; Ziegler \& Phillipson, 2012)).

So, an approach of giftedness which takes into account learning preconditions and learning processes of a student regards 'giftedness as a developmental process [...] that is domain specific and malleable' (Subotnik et al., 2011, p.6).

These considerations underline the importance of learning opportunities. Most of the tasks given in regular lessons do not challenge students with high potential. This may have the effect that students with a high potential get bored, that they withdraw themselves from classroom activities and, perhaps cannot develop their potential in an adequate manner. Thus, regarding giftedness as depending on a developmental process underlines the necessity to construct learning environments which challenge students with a high mathematical potential.

\section{The Character of Learning Environments}

Research about mathematical giftedness as well as giftedness in general provides some indications of the character of learning environments. One important hint is the efficiency in information processing in learning processes (Krause, Seidel, \& Heinrich, 2004). In line with observations of e.g. (Wieczerkowski, 1998; Krause et al., 1999; Paz-Baruch, Leikin, Aharon-Peretz, \& Leikin, 2014; Seidel et al., 2001). In our project (PriMa) we observe that the complexity of information which can be handled is an important aspect of a high mathematical potential. Another aspect is the speed in learning processes. It should be considered that students who grasp new ideas quickly do not necessarily work quickly: thinking ideas through thoroughly and reflectively needs time. 
For constructing mathematical learning environments these aspects should be complemented by components of mathematical thinking processes. Kießwetter (1985) lists so called patterns of action which are advantageous in problem solving processes (Kießwetter, 1985, 2006; Nolte, 1999):

- Organizing material in order to recognize (eventually different) patterns;

- Developing and testing of hypotheses;

- Reduction of complexity through meta-symbolization (building super signs (chunking)) recursion;

- Intuitive use of strategies already indicated or further heuristic strategies;

- Finding connected problems.

There are similarities with the characteristics of giftedness described by Krutetskii (1976) who lists as traits of mathematical giftedness e.g. the handling of complex information, the capability of generalization, skipping of steps in a solving process, the capability of reversion of thinking processes (p. 107f). His findings were confirmed for primary grade students (e.g. Aßmus, 2007; Aßmus \& Förster, 2012; Käpnick, 1998). Although many authors (e.g. Gavin et al., 2007) use Krutetskii's idea of a 'mathematical cast of mind' as a trait of mathematical giftedness it should be taken into account that the way teachers work on problems during the lessons shape the idea especially young students get of what is meant with mathematics. Therefore, eventually students who orientate their behaviour on what they think is expected by the teacher, do not show the observed mathematical capabilities (Nolte, 2018). 'Early social and educational experiences may lead young girls and boys to construct different beliefs about the system of mathematics and their place in that system' (Buchanan, 1987, p. 400).

Taken together, problems which are suitable to develop mathematical competences should be complex and offer the possibility of generalization and of further leading questions.

\section{Progressive Research Problems}

Based on these considerations we developed so called progressive research problems (PRP), initially for students of our fostering program (PriMa). Furthermore, we made investigations with students who were not identified as mathematically gifted (Nolte \& Pamperien, 2014, 2017). Progressive (research problems) means that step by step students acquire patterns of action, which 
Kießwetter defines as useful in solving mathematical problems successfully. With their complexity the problems are an interesting challenge for children with high mathematical potential. To work on them the usual knowledge of students of that age level (class level) is sufficient. Because they are self-differentiated they are also an adequate challenge for students of different level of potential. (Progressive) research problems we use as these kinds of problems support the development of capabilities which are needed in mathematical research processes. The problems are challenging due to their complexity. They are of mathematical relevance and allow stimulation of mathematical thinking processes, problem solving competence, heuristic strategies. The problems are open in a way that allows further leading questions and to open a 'field of problems.' Progressive research problems (PRP) offer 'a good chance to get a feeling of what science is and how one does "good research"' (Berman, Goldberg, \& Koichu, 2005, p. 221). We do not expect an 8 year old to do scientific research! Nevertheless, we expect the child to make first steps on his or hers way to do research! Due to the possibility of working on the problems on different levels they are suitable for fostering mathematically talented students on primary grade level and on secondary level.

Progressive research problems...

- open age-appropriate complex mathematical problem areas,

- are of mathematical relevance (stimulation of mathematical thinking processes, problem solving competence, heuristic strategies),

- start with a restricted question based on examples,

- enable a structured and quick access to the problem area,

- allow quickly success on different steps and level (providing process motivation),

- allow different ways of working on the problem and different depth of mathematical thinking processes,

- allow further leading questions (problem posing) to extend the mathematical context.

\section{How to Work on Progressive Research Problems (PRP)}

Due to the speed of grasping new ideas we present the problems at a low level of redundancy. Nevertheless at primary grade level we introduce the problems using examples. It is important for the children to be led to the mathematical core of the problem. Similar to standardizes tests they should not puzzle about the meaning of our questions. 


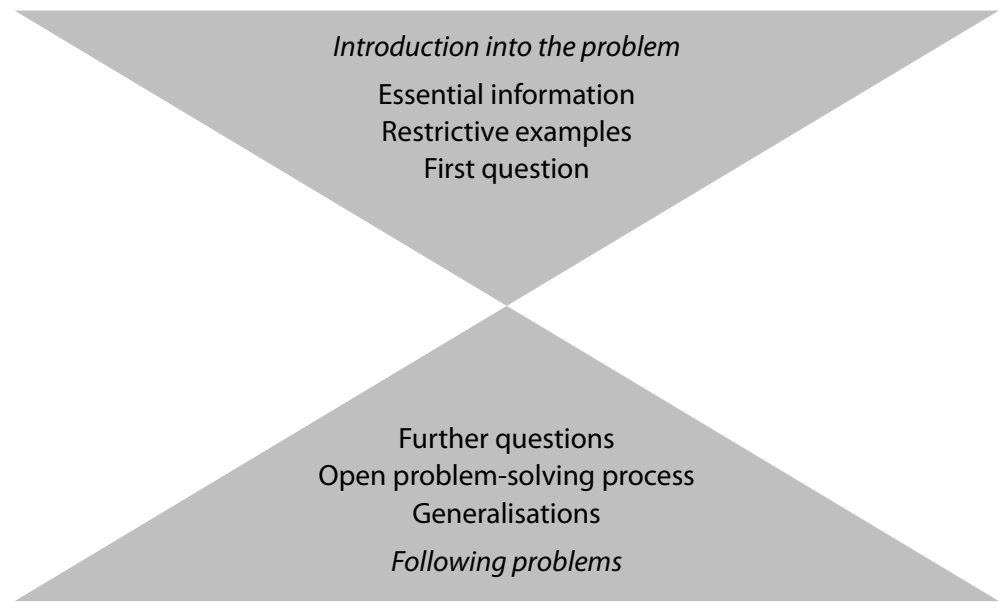

Figure 1 Hourglass Model of Progressive Research Problems

All students get the same problem. A fitting level of work is not defined by a teacher but rather by the way students work on the question. This avoids a mismatch between the given task and the potential of a student. To work on the problems need more time than students are used to. So, to support the endurance we start with an easy question at the beginning. Thus, every child gets access to the mathematical core of the problem and can be successful. Especially because the problems are complex working on them needs more time than the problems usually given in classroom. Thus, motivation at the beginning is important and also motivation by a sense of success during the problem solving process. This is an important aspect to support the development of endurance and volition. After this guiding step students can continue working the way they like. Working on the problems, children use different level of strategies. Some of them see a kind of ramp while working on the problem and with this enlarge the mathematical content to connected problems. The students are supported by teachers using scaffolding and fading strategies (Mason, Burton, \& Stacey, 2010). Here the main idea is to help as much as necessary and as little as required. In plenary discussions different ways of working on the problems, different answers and in general different ideas are discussed.

Example: Starting part of the natural numbers (Nolte, 1999). The following problem was presented to eight to ten-year-old children. Taking the first starting parts of the natural numbers (every number is used exactly once) it is possible to calculate either 1 or o by using the operations 'addition' and 
'subtraction.' Is this always possible? Can you find out which final numbers result in 1 and which in o? And can you say, why?

$-1,2,3,4$ is one starting part of the natural numbers with the final number 4.

$-1,2,3,4,5,6,7$ is one starting part of the natural numbers with the final number 7 .

If you do it in a clever way, you can construct tasks which result either in 1 or in 0 .

\section{Conditions:}

- You can only use addition or subtraction.

- You must take every number exactly once.

- The numbers have to be a starting part of the natural numbers.

Result. Four successive numbers can be termed as $a, a-1, a-2, a-3$. It follows for $a>3$ e.g. that:

$$
\begin{aligned}
& a-(a-1)+(a-3)-(a-2)=0 \text { and } a+(a-3)-(a-1)-(a-2)=0 \text {, } \\
& \text { for } a<4: 3-2-1=0 \text { and } 2-1=1
\end{aligned}
$$

With small final numbers it is possible for the children to find results by trial and error. When the figures get larger the students must set up a conjecture. After three steps Simon recognized after calculating with the final number 66:

$$
66-65+63-64+62-61+59-60+58-57+55-56 \ldots
$$

'If you calculate this way you only have to puzzle over the numbers 1, 2, or 3 at the end.' Even children at primary grade level are capable of generalize their ideas. Nevertheless, this is a problem which can be interesting also for prospective mathematics teachers.

Problem of the month's at the University of Duisburg-Essen (December 2014, see https://www.uni-due.de/didmath/problemdesmonatsarchiv.php). Given is a natural number $n$. We are looking for arithmetic problems which must follow these rules: You must use all numbers between 1 and $n$. You can only use + and - . The result of the task must be o or 1 .

Examples for these kinds of arithmetic problems are:

$$
\begin{aligned}
& 7+3-1-6+4-5-2=0 \\
& 5+2-4-3+1=1
\end{aligned}
$$


How do you get such an arithmetic problem for a given $n$ ?

In classroom students can work about a small given number. They can use trial and error to find the results. Working like this they do many calculations and train their calculation capabilities. At the same time they can recognize patterns and structures like the sequence of results of succeeding numbers: $1,1,0,0,1,1,0,0, \ldots$. A deeper insight lies in grouping four succeeding numbers like Simon did; and some of the students are able of generalize and proof their hypotheses. This problem can be extended (Kießwetter, 2006). One question lies in the effects of using e.g. odd or even numbers.

Teachers who use problems like this in a sensible way so that all students are encouraged to express their ideas have the opportunity to recognize high potential in students. While working on these kinds of problems students unfold their competencies in problem solving processes.

Potentials of progressive research problems (PRP, see Nolte, 2012):

- Enable working together on a shared mathematical object and to learn from each other (e.g. to learn and reflect different approaches),

- Support the learning of heuristics;

- Contribute to the development of problem solving competences and the ability of reasoning (especially regarding the construction of hypotheses and proving);

- Stimulate first processes of theory building and generalization;

- Provokes (written) formulation of considerations and reasoning;

- help to ensure that especially children with special gifts are challenged;

- support the recognition of special interests and talents of children;

- enable the continuation of its application at various ages.

'We define children as mathematically gifted when they are able to work on complex problems. In this learning environment they recognize patterns and structures. They are able to exploit these patterns and structures while working the problem. They can work on a high level of abstraction. They construct superordinate structures and gasp coherences. They are able to generalize their findings. So when children show special patterns of action in challenging and complex fields of problems we suppose high mathematical talent' (Nolte, 2012, p. 157).

\section{References}

Aßmus, D. (2007, March). Merkmale und Besonderheiten mathematisch potentiell begabter Grundschüler: aktuelle Forschungsergebnisse [Characteristics and peculiarities of mathematically potentially talented primary school students: Current research results]. Paper presented at the 41. 
Tagung für Didaktik der Mathematik Jahrestagung der Gesellschaft für Didaktik der Mathematik, Berlin, Germany.

Aßmus, D., \& Förster, F. (2012). Fähigkeiten zur Analogieerkennung und zum Transfer mathematischer Strukturen bei mathematisch begabten Grundschulkindern [Ability to recognize analogies and transfer mathematical structures in mathematically gifted primary school children]. Retrieved from http://www.mathematik.uni-dortmund.de/ieem/ bzmu2012/files/BzMU12_0132_Assmus.pdf

Berman, A., Goldberg, F., \& Koichu, B. (2005). 'Good research' conducted by talented high school students: The case of sci-tech. Gifted Education International, 20(2), 220-228.

Buchanan, N. K. (1987). Factors contributing to mathematical problem-solving performance: An exploratory study. Educational Studies in Mathematics, 18(4), 399-415.

Gagné, F. (2004). Transforming gifts into talents: The DMGT as a developmental theory. High Ability Studies, 15(2), 119-148.

Gavin, M. K., Casa, T. M., Adelson, J. L., Carroll, S. R., Sheffield, L. J., \& Spinelli, A. M. (2007). Project M3: Mentoring mathematical minds; A research-based curriculum for talented elementary students. Journal of Advanced Academics, 18(4), 566-585.

Heller, K. A. (2004). Identification of gifted and talented students. Psychology Science, 46(3), 302-323.

Käpnick, F. (1998). Mathematisch begabte Kinder [Mathematically Gifted Children]. Frankfurt, Germany: Peter Lang.

Kießwetter, K. (1985). Die Förderung von mathematisch besonders begabten und interessierten Schülern: ein bislang vernachlässigtes sonderpädagogisches Problem [The promotion of mathematically gifted and interested students: A so far neglected special education problem.]. Mathematisch-naturwissenschaftlicher Unterricht, 38(5), 300-306.

Kießwetter, K. (2006). Können Grundschüler schon im eigentlichen Sinne mathematisch agieren - und was kann man von mathematisch besonders begabten Grundschülern erwarten, und was noch nicht? [Can elementary students act mathematically in the true sense of the word - and what can one expect from mathematically gifted elementary students, and what not?] In H. Bauersfeld \& K. Kießwetter (Eds.), Wie fördert man mathematisch besonders befähigte Kinder? Ein Buch aus der Praxis für die Praxis [How do you promote mathematically qualified children? A book from practice for practice] (pp. 128-153). Offenburg, Germany: Mildenberger.

Krause, W., Seidel, G., \& Heinrich, F. (2004). Multimodalität am Beispiel mathematischer Anforderungen [Multimodality based on mathematical requirements]. Sitzungsberichte der Leibniz-Sozietät 64, 135-152.

Krause, W., Seidel, G., Heinrich, F., Sommerfeld, E., Gundlach, W., Ptucha, J., ... 
Goertz, R. (1999). Multimodale Repräsentation als Basiskomponente kreativen Denkens [Multimodal representation as a basic component of creative thinking]. In B. Zimmermann, G. David, T. Fritzlar, F. Heinrich \& M. Schmitz (Eds.), Kreatives Denken und Innovationen in mathematischen Wissenschaften [Creative thinking and innovations in mathematical sciences] (pp. 129-142). Jena, Germany: Friedrich-Schiller-Universität.

Krutetskii, V. A. (1976). An investigation of mathematical abilities in schoolchildren. Chicago, IL: University of Chicago.

Mason, J., Burton, L., \& Stacey, K. (2010). Thinking mathematically. Harlow, England: Pearson.

Nolte, M. (1999). Are elementary school pupils already able to perform creatively substantial bricks of knowledge? A report on first striking findings from working with smaller groups of highly gifted and motivated elementary school pupils aged 8-10. In H. Meissner, M. Grassmann \& S. MuellerPhilipp (Eds.), Creativity and mathematics education (pp. 142-145). Münster: Westfälische Wilhelms-Universität.

Nolte, M. (2012). Mathematically gifted young children: Questions about the development of mathematical giftedness. In H. Stöger, A. Aljughaiman \& B. Harder (Eds.), Talent development and excellence (pp. 155-176). Berlin, Germany: Lit.

Nolte, M. (2018). Twice-exceptional students: Students with special needs and a high mathematical potential. In F. M. Singer (Ed.), Mathematical creativity and mathematical giftedness: Enhancing creative capacities in mathematically promising students (pp. 199-225). Cham, Switzerland: Springer.

Nolte, M., \& Pamperien, K. (2014, July). Conditions of success of mathematical gifted young children with migration background in a talent search process. Paper presented at the 8th conference of the International Group for Mathematical Creativity and Giftedness, Denver, CO.

Nolte, M., \& Pamperien, K. (2017). Challenging problems in a regular classroom setting and in a special foster programme. Zentralblatt für Didaktik der Mathematik, 49(1), 121-136.

Paz-Baruch, N., Leikin, M., Aharon-Peretz, J., \& Leikin, R. (2014). Speed of information processing in generally gifted and excelling-in-mathematics adolescents. High Ability Studies, 25(2), 143-167.

Seidel, G., Krause, W., Schack, B., Heinrich, F., Krause, U., Wiistenberg, T., ... Jincke, L. (2001). Entropy reduction and mathematical giftedness: A microstate study of EEG oscillations. Neurolmage, 13(6), 474.

Singer, F. M., Sheffield, L. J., Freiman, V., \& Brandl, M. (2016). Research on and activities for mathematically gifted students. Cham, Switzerland: Springer.

Subotnik, R. F., Olszewski-Kubilius, P., \& Worrell, F. C. (2011). Rethinking giftedness and gifted education. Psychological Science in the Public Interest, 12(1), $3-54$. 
Wieczerkowski, W. (1998). Vier hochbegabte Grundschüler in beratungspsychologischer Perspektive [Four highly gifted elementary students in counseling psychological perspective]. Psychologie in Erziehung und Unterricht, 45, 143-159.

Ziegler, A., \& Phillipson, S. N. (2012). Towards a systemic theory of giftedness. High Ability Studies, 23(1), 3-30. 

